SRNL-STI-2012-00123

Revision 0

Keywords: SEM, XRD

Retention: Permanent

\title{
Scanning Electron Microscopy and X-Ray Diffraction Analysis of Tank 18 Samples
}

M. S. Hay

P. E. O'Rourke

H. M. Ajo

March 2012

Savannah River National Laboratory

Savannah River Nuclear Solutions, LLC Aiken, SC 29808

Prepared for the U.S. Department of Energy under contract number DE-AC09-08SR22470.

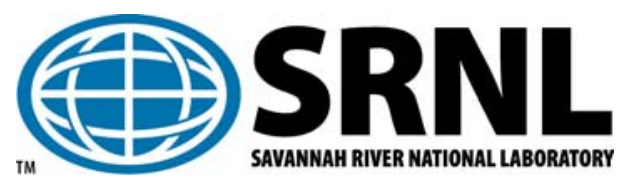


SRNL-STI-2012-00123

Revision 0

\section{DISCLAIMER}

This work was prepared under an agreement with and funded by the U.S. Government. Neither the U.S. Government or its employees, nor any of its contractors, subcontractors or their employees, makes any express or implied:

1. warranty or assumes any legal liability for the accuracy, completeness, or for the use or results of such use of any information, product, or process disclosed; or

2. representation that such use or results of such use would not infringe privately owned rights; or

3. endorsement or recommendation of any specifically identified commercial product, process, or service.

Any views and opinions of authors expressed in this work do not necessarily state or reflect those of the United States Government, or its contractors, or subcontractors.

\section{Printed in the United States of America}

Prepared for

U.S. Department of Energy 
SRNL-STI-2012-00123

Revision 0

\section{REVIEWS AND APPROVALS}

\section{AUTHORS:}

M. S. Hay, Author, SRNL/ACP

Date

P. E. O'Rourke, Author, SRNL/AD

Date

H. M. Ajo, Author, SRNL/AD

Date

TECHNICAL REVIEW:

S. H. Reboul, SRNL/PTP

Date

APPROVAL:

F. M. Pennebaker, SRNL/ACP

Date

S. L. Marra, SRNL/E\&CPT Research Programs

Date

K. H. Rosenberger, SRR Closure and Disposal Assessment

Date 
SRNL-STI-2012-00123

Revision 0

\section{EXECUTIVE SUMMARY}

The F-Area Tank Farm (FTF) Performance Assessment (PA) utilizes waste speciation in the waste release model used in the FTF fate and transport modeling. The waste release modeling associated with the residual plutonium in Tank 18 has been identified as a primary contributor to the Tank 18 dose uncertainty. In order to reduce the uncertainty related to plutonium in Tank 18, a better understanding of the plutonium speciation in the Tank 18 waste (including the oxidation state and stoichiometry) is desired. Savannah River National Laboratory (SRNL) utilized Scanning Electron Microscopy (SEM) and Xray Diffraction (XRD) to analyze Tank 18 samples to provide information on the speciation of plutonium in the waste material.

XRD analysis of the Tank 18 samples did not identify any plutonium mineral phases in the samples. These indicates the crystalline mineral phases of plutonium are below the detection limits of the XRD method or that the plutonium phase(s) lack long range order and are present as amorphous or microcrystalline solids.

SEM analysis of the Tank 18 samples did locate particles containing plutonium. The plutonium was found as small particles, usually $<1 \mu \mathrm{m}$ but ranging up to several micrometers in diameter, associated with particles of an iron matrix and at low concentration in other elemental matrices. This suggests the plutonium has an affinity for the iron matrix. Qualitatively, the particles of plutonium found in the SEM analysis do not appear to account for all of the plutonium in the sample based on concentrations determined from the chemical analysis of the Tank18 samples. This suggests that plutonium is also distributed throughout the solids in low concentrations. 


\section{TABLE OF CONTENTS}

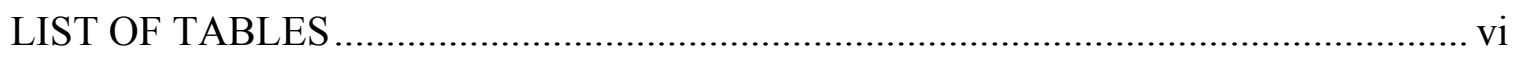

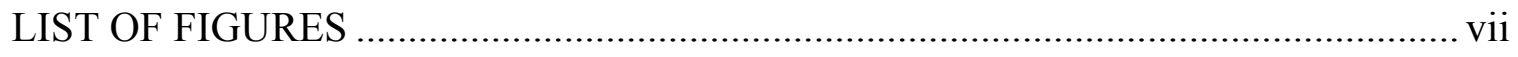

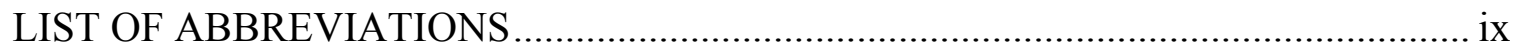

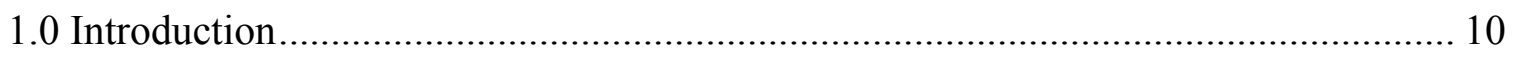

2.0 Experimental Procedure ............................................................................... 10

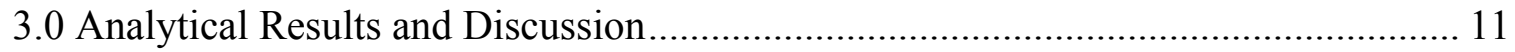

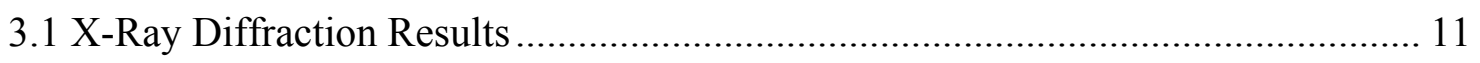

3.2 Scanning Electron Microscopy Results ................................................................ 14

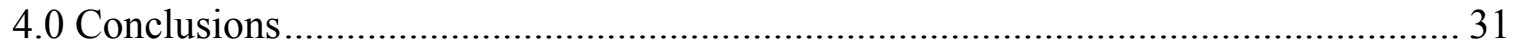

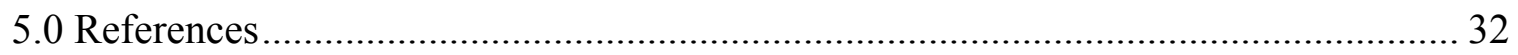

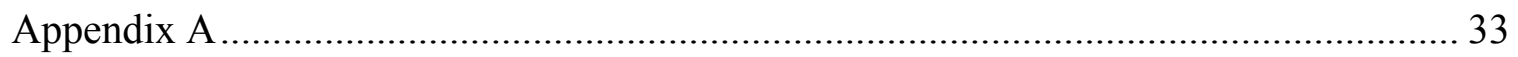


SRNL-STI-2012-00123

Revision 0

\section{LIST OF TABLES}

Table 3-1. Mineral Phases Identified in Tank 18 Sample FTF-18-1 by XRD ................ 12

Table 3-2. Summary of the Chemical Composition of the Tank 18 Floor Samples (wt\%

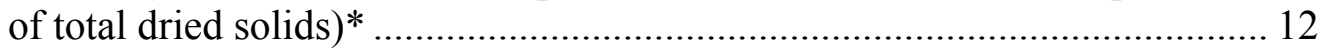

Table 3-3. Spots from Figure 3-15 Found to Contain Plutonium ................................ 30 
SRNL-STI-2012-00123

Revision 0

\section{LIST OF FIGURES}

Figure 3-1 XRD Results for Tank 18 Sample FTF-18-1 with Peak Assignments ........ 13

Figure 3-2 XRD Results for Tank 18 Sample FTF-18-1 without Peak Assignments ... 13

Figure 3-3 XRD Results for Tank 18 Wall Scale Sample (reference 6) ...................... 14

Figure 3-4 Low Magnification Image of FTF-18-1 ............................................ 17

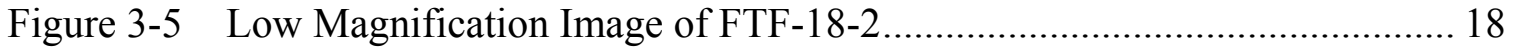

Figure 3-6 Elemental Mapping of Site 1 of FTF-18-1 ............................................. 19

Figure 3-7 Elemental Mapping of Site 2 of FTF-18-1 ......................................... 20

Figure 3-8 Two Iron Oxide Matrices in Tank 18 Sample FTF-18-2 ......................... 21

Figure 3-9 Higher Magnification of Porous Iron Oxide Matrix Containing Plutonium Particles in Sample FTF-18-2 ............................................................ 22

Figure 3-10 Higher Magnification of Porous Iron Oxide Matrix Containing Plutonium Particles in Sample FTF-18-1 ............................................................ 23

Figure 3-11 Higher Magnification of Porous Iron Oxide Matrix Containing Plutonium Particles in Sample FTF-18-3 .............................................................. 24

Figure 3-12 Grid Analysis of Matrix Containing Plutonium Particles in Sample FTF-183.

Figure 3-13 Higher Magnification of Porous Iron Oxide Phase Containing Plutonium Particles in Sample FTF-18-4 ............................................................. 26

Figure 3-14 Grid Analysis of Matrix Containing Plutonium Particles in Sample FTF-184.

Figure 3-15 WDS Grid Analysis of Matrix Containing Plutonium Particles in Sample

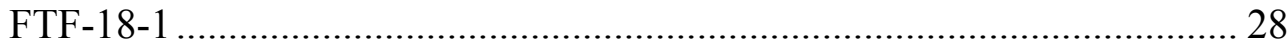

Figure A-1 Micrographs and Spectra of Spots on Particles in Sample FTF-18-1 _........ 34

Figure A-2 Micrographs and Spectra of Spots on Particles in Sample FTF-18-1 ......... 36

Figure A-3 Micrographs and Spectra of Spots on Particles in Sample FTF-18-1 f........ 37

Figure A-4 WDS Grid Analysis of Matrix Containing Plutonium Particles in Sample

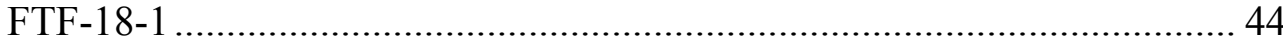

Figure A-5 EDS Grid Analysis of Spots on Particles in Sample FTF-18-3 ................. 50 
SRNL-STI-2012-00123

Revision 0

Figure A-6 EDS Grid Analysis of Spots on Particles in Sample FTF-18-3 ................. 53

Figure A-7 EDS Grid Analysis of Spots on Particles in Sample FTF-18-4 …............. 57

Figure A-8 EDS Grid Analysis of Spots on Particles in Sample FTF-18-4 ................ 61

Figure A-9 EDS Analysis of Spot on a Particle in Sample FTF-18-4 ......................... 66

Figure A-10 EDS Grid Analysis of a Uranium Particle in Sample FTF-18-4 ............... 67

Figure A-11 EDS Grid Analysis of a Uranium Particle in Sample FTF-18-4 ............... 68

Figure A-12 EDS Grid Analysis of Spots on Particles in Sample FTF-18-4 .................. 69 
SRNL-STI-2012-00123

Revision 0

\section{LIST OF ABBREVIATIONS}

$\begin{array}{ll}\text { AD } & \text { Analytical Development } \\ \text { EDS } & \text { Energy-Dispersive X-ray Spectroscopy } \\ \text { FTF } & \text { F-Area Tank Farm } \\ \text { PA } & \text { Performance Assessment } \\ \text { SEM } & \text { Scanning Electron Microscopy } \\ \text { SRNL } & \text { Savannah River National Laboratory } \\ \text { TTR } & \text { Technical Task Request } \\ \text { WDS } & \text { Wavelength-Dispersive X-ray Spectroscopy } \\ \text { XRD } & \text { X-Ray Diffraction }\end{array}$


SRNL-STI-2012-00123

Revision 0

\subsection{Introduction}

The F-Area Tank Farm (FTF) Performance Assessment (PA) utilizes waste speciation in the waste release model used in the FTF fate and transport modeling. The waste release modeling associated with the residual plutonium in Tank 18 has been identified as a primary contributor to the Tank 18 dose uncertainty. In order to reduce the uncertainty related to plutonium in Tank 18, a better understanding of the plutonium speciation in the Tank 18 waste (including the oxidation state and stoichiometry) is desired. Savannah River National Laboratory (SRNL) utilized Scanning Electron Microscopy (SEM) and Xray Diffraction (XRD) to analyze Tank 18 samples to provide information on the speciation of plutonium in the waste material. The work was conducted as stated in the task plan $^{1}$ developed based on the Technical Task Request (TTR). ${ }^{2}$

\subsection{Experimental Procedure}

Samples from Tank 18 used in the analysis were previously characterized. ${ }^{3}$ The samples had been air dried, ground using a mortar and pestle, and sieved through a 30 mesh (600 $\mu \mathrm{m})$ screen as part of the previous characterization sample preparation. The four samples chosen for the current analysis were FTF-18-1, FTF-18-2, FTF-18-3, and FTF-18-4. Sample FTF-18-1 was chosen for the current analysis due to having the highest plutonium concentration of the Tank 18 sample available (see Table 3-2). The other three samples chosen for the current analysis provided material from a variety of areas in the tank.

For the XRD analysis, approximately $100 \mathrm{mg}$ of solids from FTF-18-1 were delivered to Analytical Development (AD) in a shielded bottle.

The samples for the SEM were prepared in the Shielded Cells by adding a small amount of the solids from each of the four samples into a $\sim 1 / 2$ " diameter metal ring sitting in the bottom of a round plastic mold. The metal ring was used to contain the sample material in a central location and minimize the amount of radioactive sample required. A low viscosity two part epoxy was mixed outside the Shielded Cells and degassed to remove bubbles. The epoxy was quickly entered into the Shielded Cells and carefully poured into the molds. After the epoxy had cured, the epoxy pucks containing the sample were removed from the molds and ground/polished using a MiniMet ${ }^{\circledR} 1000$ Semi-Automatic Grinder/Polisher contained in the Shielded Cells. The objective of the grinding/polishing was to reveal cross-sectional views of the particles in the sample.

A LEO S440 Scanning Electron Microscope was used for analysis of the Tank 18 samples. The LEO S440 SEM uses a tungsten filament electron source with an accelerating voltage up to $30 \mathrm{kV}$ with capability of secondary electron and backscatter electron imaging. The instrument includes an Oxford Instruments liquid-nitrogen cooled $\mathrm{Si}(\mathrm{Li})$ energy dispersive spectrometer (EDS) and an Oxford Instruments wavelength dispersive spectrometer (WDS) both controlled using INCA software. 
SRNL-STI-2012-00123

Revision 0

\subsection{Analytical Results and Discussion}

\subsection{X-Ray Diffraction Results}

An XRD analysis of the Tank 18 floor material (FTF-18-1) identified the crystalline mineral phases listed in Table 3-1 along with the estimated percent content. Figures 3-1 and 3-2 show the background corrected spectrum with and without peak assignments for the sample. Table 3-2 shows the main components of the solids from the Tank 18 sample as measured during a previous chemical characterization. ${ }^{3}$ The major elements present in the sample include $\mathrm{Al}, \mathrm{Fe}, \mathrm{Na}, \mathrm{U}, \mathrm{Si}, \mathrm{Mg}$, and $\mathrm{Ca}$. The results of the XRD generally agree with the chemical composition determined for Tank 18 waste. However, the estimated uranium content from the XRD is much higher than the concentration determined by the chemical characterization.

The phase identification software identified two uranium containing phases in the sample. The uranyl carbonate phase is consistent with the high carbonate concentrations found in the Tank 18 waste. ${ }^{3}$ The chemical analysis also found relatively high, water-leachable, fluoride concentrations in the Tank 18 solids suggesting at least the possibility of forming the uranium fluoride phase identified in the XRD. The mineral Clarkeite $\left(\mathrm{Na}_{2}\left(\mathrm{UO}_{2}\right)_{2} \mathrm{O}(\mathrm{OH})\left(\mathrm{H}_{2} \mathrm{O}\right)\right)$ is a uranium phase commonly found in SRS tank waste. ${ }^{4,5}$ The Clarkeite may have converted to a uranyl carbonate phase as the carbonate concentration in the tank increased over time. A similar mechanism has been postulated for plutonium species in the Tank 18 waste. $^{6}$

An XRD of a Tank 18 wall sample (Figure 3-3) found similar mineral phases for the major components of the waste, although some of the minor phases were different between the floor and wall samples. ${ }^{5}$ No plutonium containing crystalline phases were detected in the XRD of the floor or wall samples from Tank 18. This indicates a plutonium concentration below the detection limits of the method or plutonium phase(s) with a non-crystalline structure (i.e., amorphous). 
Table 3-1. Mineral Phases Identified in Tank 18 Sample FTF-18-1 by XRD

\begin{tabular}{|l|c|c||}
\hline Mineral Phase & Formula & $\begin{array}{c}\text { Estimated } \\
\text { Percentage of } \\
\text { Sample }\end{array}$ \\
\hline Gibbsite & $\mathrm{Al}(\mathrm{OH})_{3}$ & $15-20 \%$ \\
\hline $\begin{array}{l}\text { Nitrated Sodium Aluminum } \\
\text { Silicate }\end{array}$ & $\mathrm{Na}_{6}\left(\mathrm{Al}_{6} \mathrm{Si}_{6} \mathrm{O}_{24}\right)\left(\mathrm{NO}_{3}\right)_{2} \cdot 4 \mathrm{H}_{2} \mathrm{O}$ & $5-10 \%$ \\
\hline Hematite & $\mathrm{Fe}_{2} \mathrm{O}_{3}$ & $5-10 \%$ \\
\hline Cejkaite & $\mathrm{Na}_{4} \mathrm{UO}_{2}\left(\mathrm{CO}_{3}\right)_{3}$ & $20-30 \%$ \\
\hline $\begin{array}{l}\text { Uranyl Hydrogen Fluoride } \\
\text { Hydrate }\end{array}$ & $\mathrm{UO}_{2} \mathrm{HF}_{3} \cdot 2 \mathrm{H}_{2} \mathrm{O}$ & $10-15 \%$ \\
\hline Calcite & $\mathrm{CaCO}_{3}$ & $5-10 \%$ \\
\hline
\end{tabular}

Table 3-2. Summary of the Chemical Composition of the Tank 18 Floor Samples (wt \% of total dried solids)*

\begin{tabular}{|l|c|c|c|c||}
\hline Element & $\begin{array}{c}\text { FTF-18-1 } \\
\text { wt\% }\end{array}$ & $\begin{array}{c}\text { FTF-18-2 } \\
\text { wt\% }\end{array}$ & $\begin{array}{c}\text { FTF-18-3 } \\
\text { wt\% }\end{array}$ & $\begin{array}{c}\text { FTF-18-4 } \\
\text { wt\% }\end{array}$ \\
\hline $\mathrm{Al}$ & $1.10 \mathrm{E}+01$ & $1.39 \mathrm{E}+01$ & $1.66 \mathrm{E}+01$ & $1.70 \mathrm{E}+01$ \\
\hline $\mathrm{Ca}$ & $2.93 \mathrm{E}+00$ & $2.13 \mathrm{E}+00$ & $1.93 \mathrm{E}+00$ & $2.29 \mathrm{E}+00$ \\
\hline $\mathrm{Cd}$ & $9.12 \mathrm{E}-01$ & $5.41 \mathrm{E}-01$ & $4.89 \mathrm{E}-01$ & $5.52 \mathrm{E}-01$ \\
\hline $\mathrm{Fe}$ & $9.76 \mathrm{E}+00$ & $6.96 \mathrm{E}+00$ & $7.29 \mathrm{E}+00$ & $7.45 \mathrm{E}+00$ \\
\hline $\mathrm{Mg}$ & $3.76 \mathrm{E}+00$ & $1.78 \mathrm{E}+00$ & $2.09 \mathrm{E}+00$ & $1.49 \mathrm{E}+00$ \\
\hline $\mathrm{Mn}$ & $1.04 \mathrm{E}+00$ & $8.31 \mathrm{E}-01$ & $7.85 \mathrm{E}-01$ & $9.66 \mathrm{E}-01$ \\
\hline $\mathrm{Ni}$ & $1.31 \mathrm{E}-01$ & $8.30 \mathrm{E}-02$ & $9.23 \mathrm{E}-02$ & $7.98 \mathrm{E}-02$ \\
\hline $\mathrm{Si}$ & $2.16 \mathrm{E}+00$ & $2.95 \mathrm{E}+00$ & $2.22 \mathrm{E}+00$ & $3.75 \mathrm{E}+00$ \\
\hline $\mathrm{U}$ & $6.29 \mathrm{E}+00$ & $3.66 \mathrm{E}+00$ & $1.55 \mathrm{E}+00$ & $1.24 \mathrm{E}+00$ \\
\hline $\mathrm{Hg}$ & $7.20 \mathrm{E}-02$ & $3.53 \mathrm{E}-02$ & $2.47 \mathrm{E}-02$ & $5.04 \mathrm{E}-02$ \\
\hline $\mathrm{Pu}$ & $2.80 \mathrm{E}-02$ & $1.55 \mathrm{E}-02$ & $1.13 \mathrm{E}-02$ & $1.16 \mathrm{E}-02$ \\
\hline
\end{tabular}

*Composition of samples taken from reference 3. 
SRNL-STI-2012-00123

Revision 0

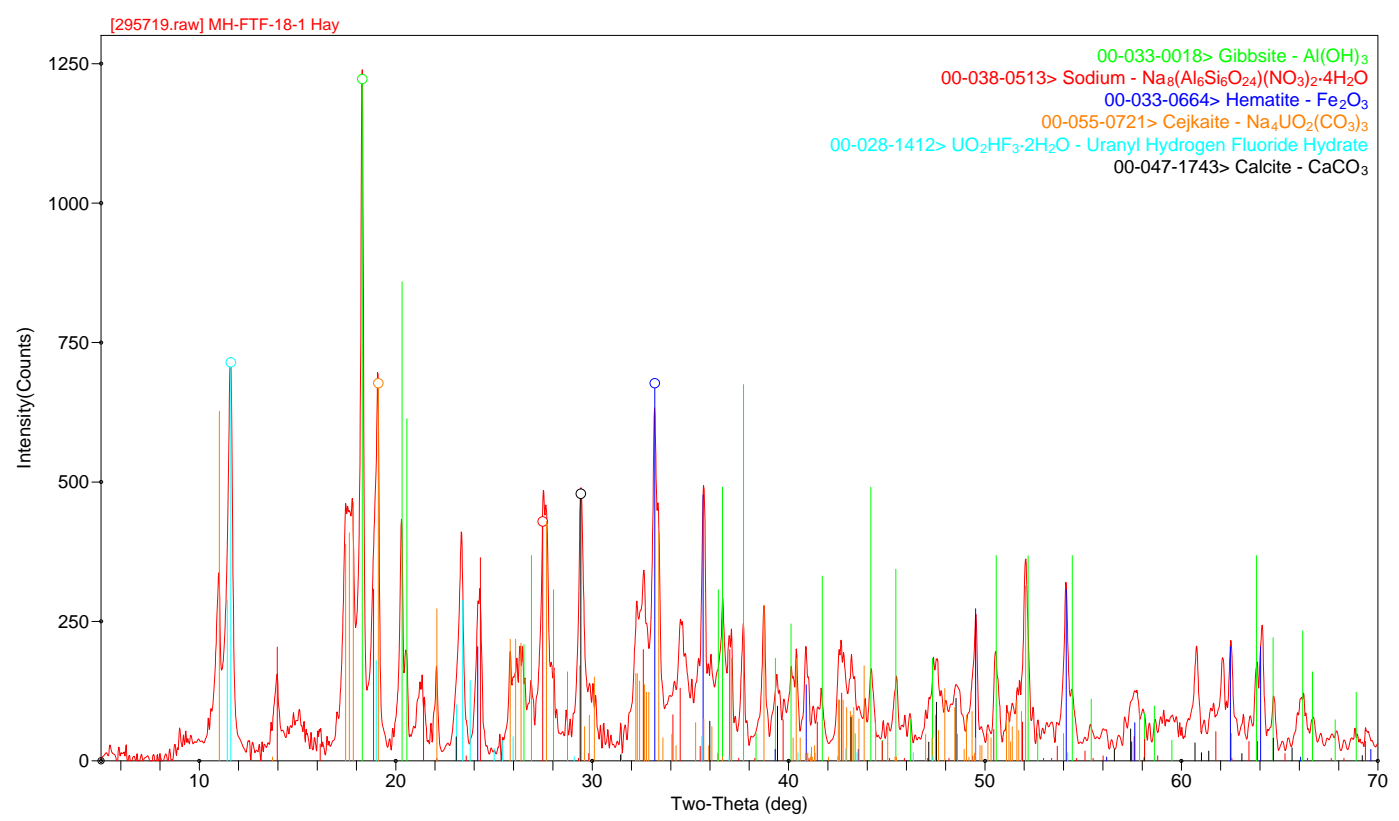

Figure 3-1 XRD Results for Tank 18 Sample FTF-18-1 with Peak Assignments

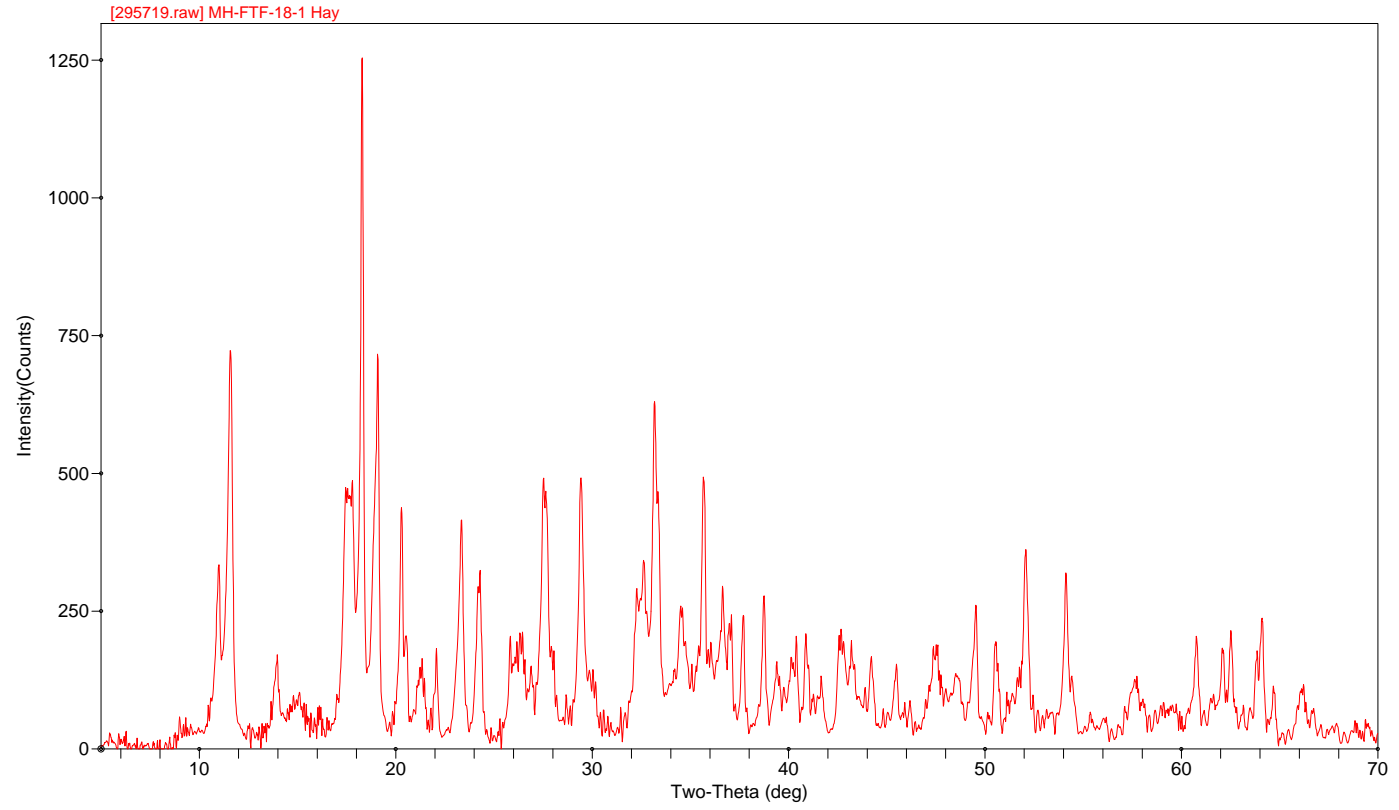

Figure 3-2 XRD Results for Tank 18 Sample FTF-18-1 without Peak Assignments 


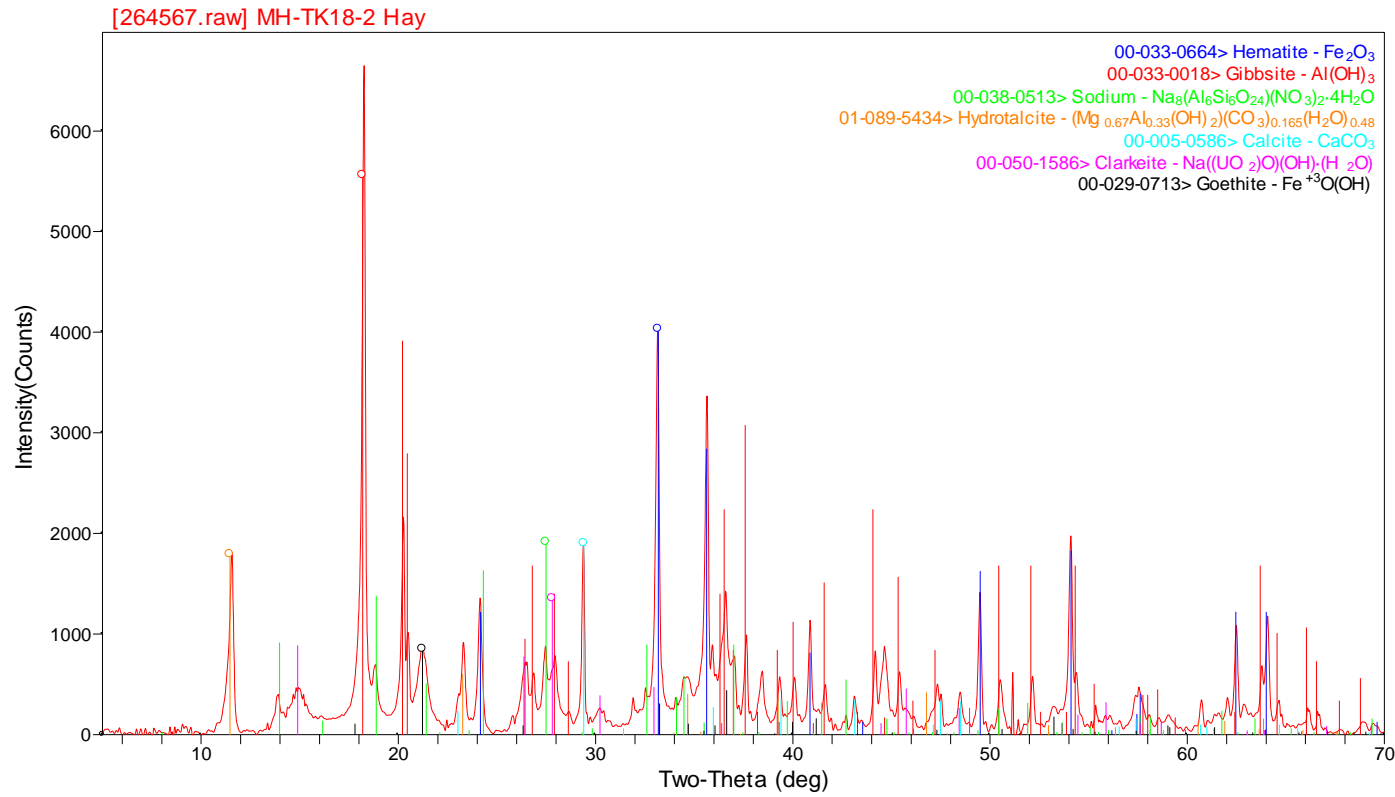

Figure 3-3 XRD Results for Tank 18 Wall Scale Sample (reference 6)

\subsection{Scanning Electron Microscopy Results}

The Tank 18 samples were analyzed by SEM using both the EDS and WDS spectrometers. Typically, the sample was placed in the instrument and EDS was used to obtain raster scans of larger areas of the sample. The EDS system was also used to generate elemental maps and look through all the brighter spots, which are indicative of higher electron density and higher atomic number, for plutonium particles. The WDS, with lower detection capability, was used to look for smaller plutonium particles in areas where larger plutonium particles were found, search grid patterns, and develop more quantitative data on lower concentration limits for plutonium in the samples. Many more spots were interrogated with both the EDS and WDS systems to determine chemical composition than the representative samples that are presented in the following photographs/spectra.

In general, the SEM analysis of the Tank 18 floor material found an elemental composition consistent with the mineral phases identified in the XRD. Figures 3-4 and 35 show the results of scans over a large area of sample FTF-18-1 and FTF-18-2, respectively. The spectra shown below each micrograph (photograph) provide the elemental composition of the material within the box marked on the micrograph. The major elements identified are also generally consistent with the elemental composition determined by the chemical characterization of the Tank 18 floor samples. ${ }^{3}$ The majority of the individual particles scanned on each sample were found to consist of a matrix 
containing aluminum and silicon with smaller quantities of other elements present. The next most abundant particles contained an iron rich matrix with low concentrations of other elements. As might be expected in a complex waste stream, many of the particles in the samples consisted of mixtures of different matrices or inclusions of a different metal matrix within the particle.

\section{$\underline{\text { EDS Results }}$}

The EDS system was used to provide elemental maps of sample FTF-18-1. Figures 3-6 and 3-7 show the color maps of $\mathrm{Al}, \mathrm{Fe}, \mathrm{U}, \mathrm{Mg}, \mathrm{Ca}$, and $\mathrm{O}$ at two different sites of sample FTF-18-1. The elemental maps suggest some segregation of $\mathrm{Al}$ and Fe materials within the sample particles, especially in the maps from Site 2 (Figure 3-7). The U at Site 1 appears to be clumped into larger particles somewhat associated with areas containing $\mathrm{Fe}$. The areas of high uranium content appear to be segregated from areas of high aluminum content in both figures. Unfortunately, plutonium was too low in concentration in these particles to map accurately.

Two distinct iron matrices were observed in the SEM with one appearing to be denser than the other. The two particles marked Spot 1 in the micrograph of Figure 3-8 point to the iron matrix that appears to be more dense (brighter particles in the photos). Spot 2 points out the less dense iron matrix. The less dense iron matrix generally contained more aluminum, magnesium, uranium, and calcium than the denser iron matrix.

All of the plutonium particles found during the SEM-EDS analysis of the four Tank 18 floor samples were associated with the less dense iron matrix. The term "associated with" is used deliberately since the SEM analysis provides no information about the chemical bonding or the chemical behavior of the plutonium in the samples. Figure 3-9 shows the location of several plutonium particles within an iron matrix of sample FTF-18-2. Figure 3-10 shows a plutonium particle in sample FTF-18-1. This plutonium particle seems to be associated with an iron matrix, but some inclusions of an aluminum matrix lie next to the particle. Figures 3-11 and 3-13 show plutonium particles located in samples FTF-18-3 and FTF-18-4 respectively. Figures 3-12 and 3-14 provide the composition of the material surrounding the plutonium particles. A grid of spots on the larger particles containing the small plutonium particles were analyzed for samples FTF-18-3 and FTF18-4. In Figure 3-12, spots 1 through 9 showed a similar iron matrix with the exception of spot 5 that contained high concentrations of Ca. All of the spots in Figure 3-14 showed a similar iron matrix spectrum.

The plutonium identified in the samples was in the form of discrete particles usually $<1$ $\mu \mathrm{m}$, but ranging up to several micrometers in diameter. The plutonium particles were spread unevenly within the iron matrix. The spectrum of the plutonium spots indicate the plutonium is likely a discrete plutonium particle associated with the iron matrix. Due to the small size and low concentration of the plutonium particles, the chemical form of the plutonium remains uncertain. The scan of the small plutonium particles invariably includes some of the background iron matrix as a result of the larger interaction volume of the electron beam. Qualitatively, the particles of plutonium found in the SEM analysis 
do not appear to account for all of the plutonium in the sample based on concentrations determined from the chemical analysis of the Tank18 samples. A simplified calculation that uses the volume interrogated by the SEM, relevant sample characteristics, and some simplifying assumptions indicates that roughly a million $\sim 1 \mu \mathrm{m}$ plutonium particles should be visible in a photograph such as figure 3-15. The assumptions used in the calculation include; plutonium particles present as homogenously distributed $\mathrm{PuO}_{2}$ with a diameter of $1 \mu \mathrm{m}$ and a density of $11.5 \mathrm{~g} / \mathrm{cm}^{3}$, a molecular mass of $276 \mathrm{~g} / \mathrm{mole}$, a plutonium concentration of $250 \mathrm{mg} / \mathrm{kg}$ in the sample, a bulk sample density of $2.0 \mathrm{~g} / \mathrm{cm}^{3}$, and an SEM sampling depth of $10 \mu \mathrm{m}$. This suggests that plutonium is also distributed throughout the solids in low concentrations.

The appendix contains additional photographs and spectra for each of the Tank 18 samples.

\section{$\underline{\text { WDS Results }}$}

The WDS results account for some of the plutonium that is not readily visible by inspection of SEM images. Figure 3-15 shows a sixteen point grid on a particle with an iron matrix in sample FTF-18-1. The lower detection limits for plutonium with the WDS system allowed identification of plutonium at several places in the grid. Table 3-3 shows several spots in Figure 3-15 containing plutonium above the Limit of Detection (LOD). The figure shows the spectra for several of the spots in the photograph. Additional spectra for the figure can be found in the appendix. In some cases the plutonium was just above the detection limit.

The plutonium LOD for WDS is $\sim 0.04 \mathrm{wt} \%$ based on 3-sigma counting statistics. The plutonium estimated uncertainty of $+/-30 \%$ for values $<0.1 \mathrm{wt} \%$ is based on 2-sigma counting statistics. If there is no background subtraction, sigma is the counting uncertainty that is the square root of the number of counts. In this case, because the background is subtracted from the peak, sigma is the square root of the sum of the number of counts of the signal peak and background peaks. EDS numerical results are for trend analysis only and are normalized to $100 \%$. EDS results are semi-quantitative estimates based on standardless analysis and theoretical intensity corrections from Oxford Instruments INCA 4.15 EDS software. Oxygen was calculated by stoichiometry, assuming $\mathrm{Na}_{2} \mathrm{O}, \mathrm{MgO}, \mathrm{Al}_{2} \mathrm{O}_{3}, \mathrm{SiO}_{2}, \mathrm{CaO}, \mathrm{MnO}, \mathrm{Fe}_{2} \mathrm{O}_{3}, \mathrm{UO}_{2}$. Plutonium is not included in the oxygen calculation. The sensitivity for the WDS measurements is based on counting statistics and combined EDS/WDS data from uranium, present in larger quantities in the sample and confirmed by measurements on plutonium, that has an essentially identical sensitivity in WDS. In WDS, the presence of uranium interferes with the detection of plutonium since the peaks for both elements lie close together. However, the uranium can be subtracted out to determine plutonium concentrations. 
SRNL-STI-2012-00123

Revision 0

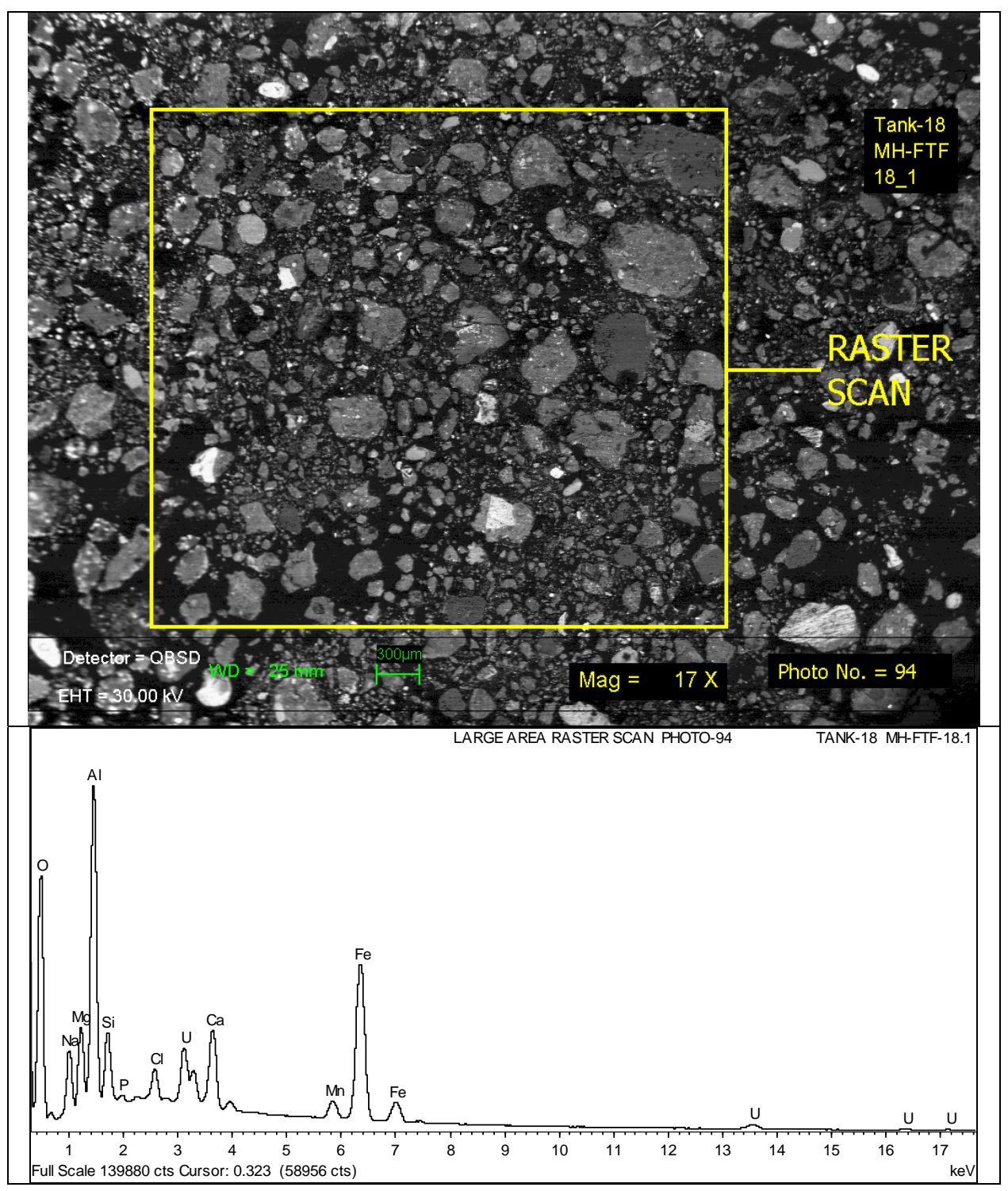

Figure 3-4 Low Magnification Image of FTF-18-1 
SRNL-STI-2012-00123

Revision 0

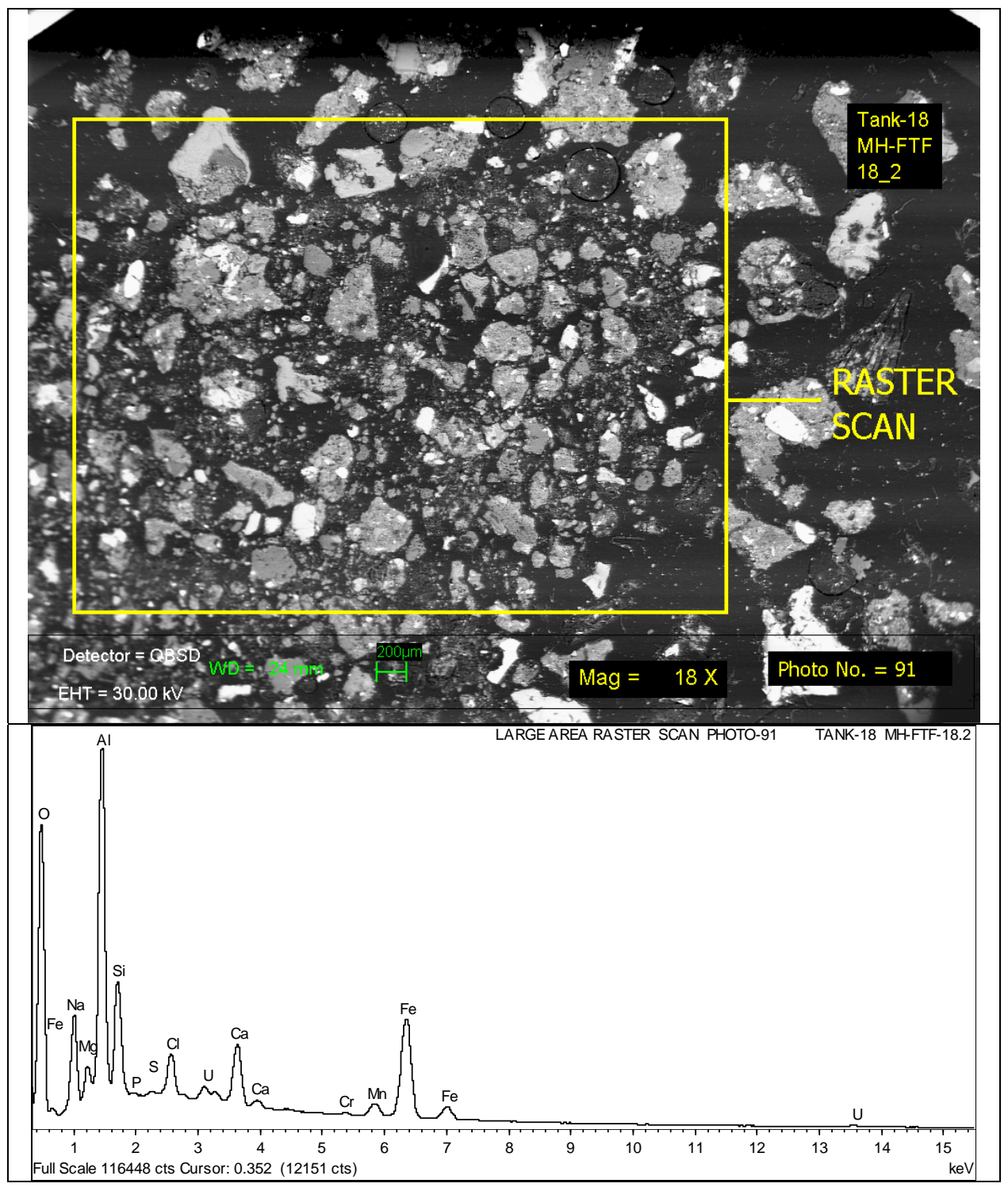

Figure 3-5 Low Magnification Image of FTF-18-2 
SRNL-STI-2012-00123

Revision 0

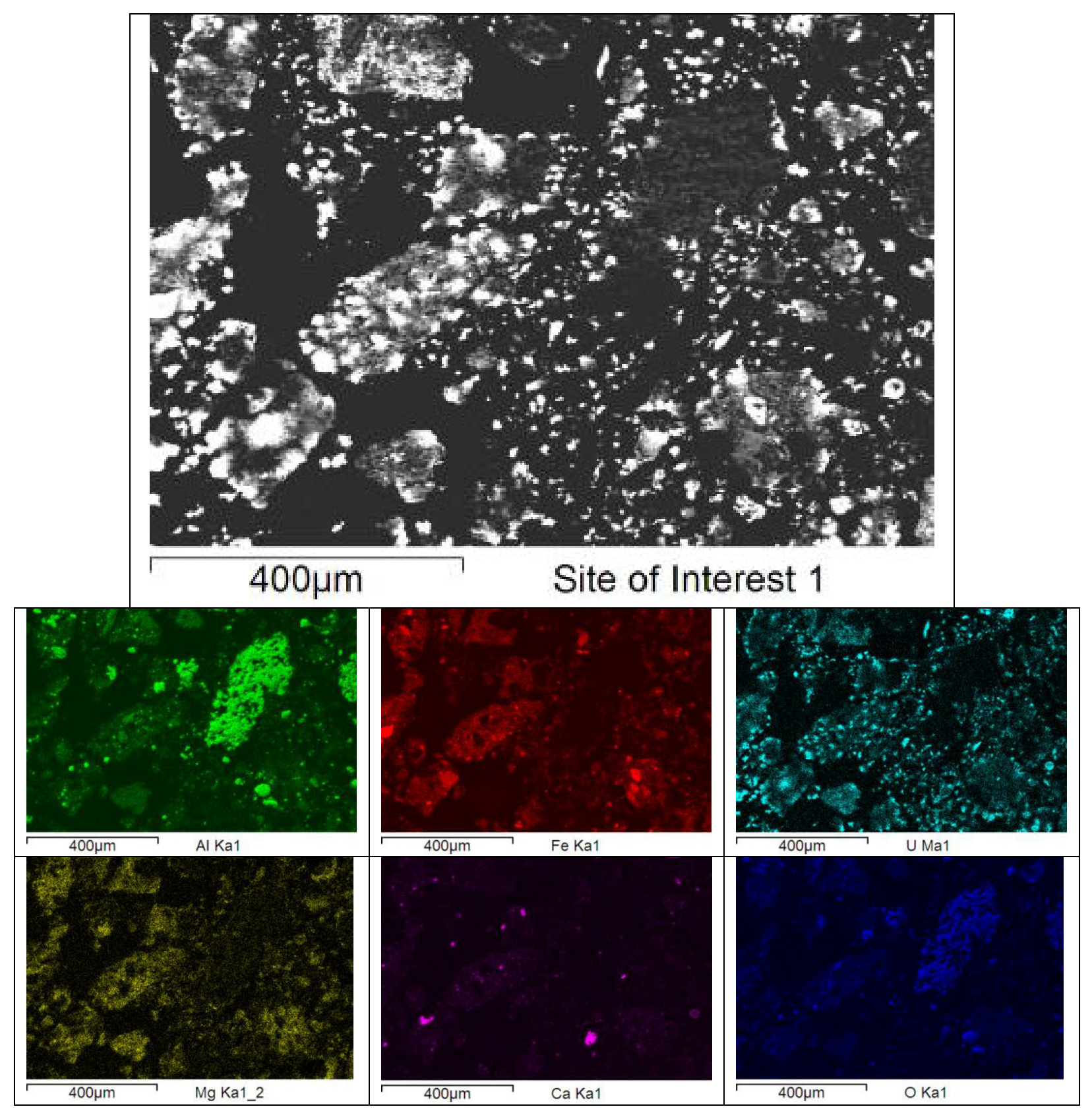

Figure 3-6 Elemental Mapping of Site 1 of FTF-18-1 
SRNL-STI-2012-00123

Revision 0

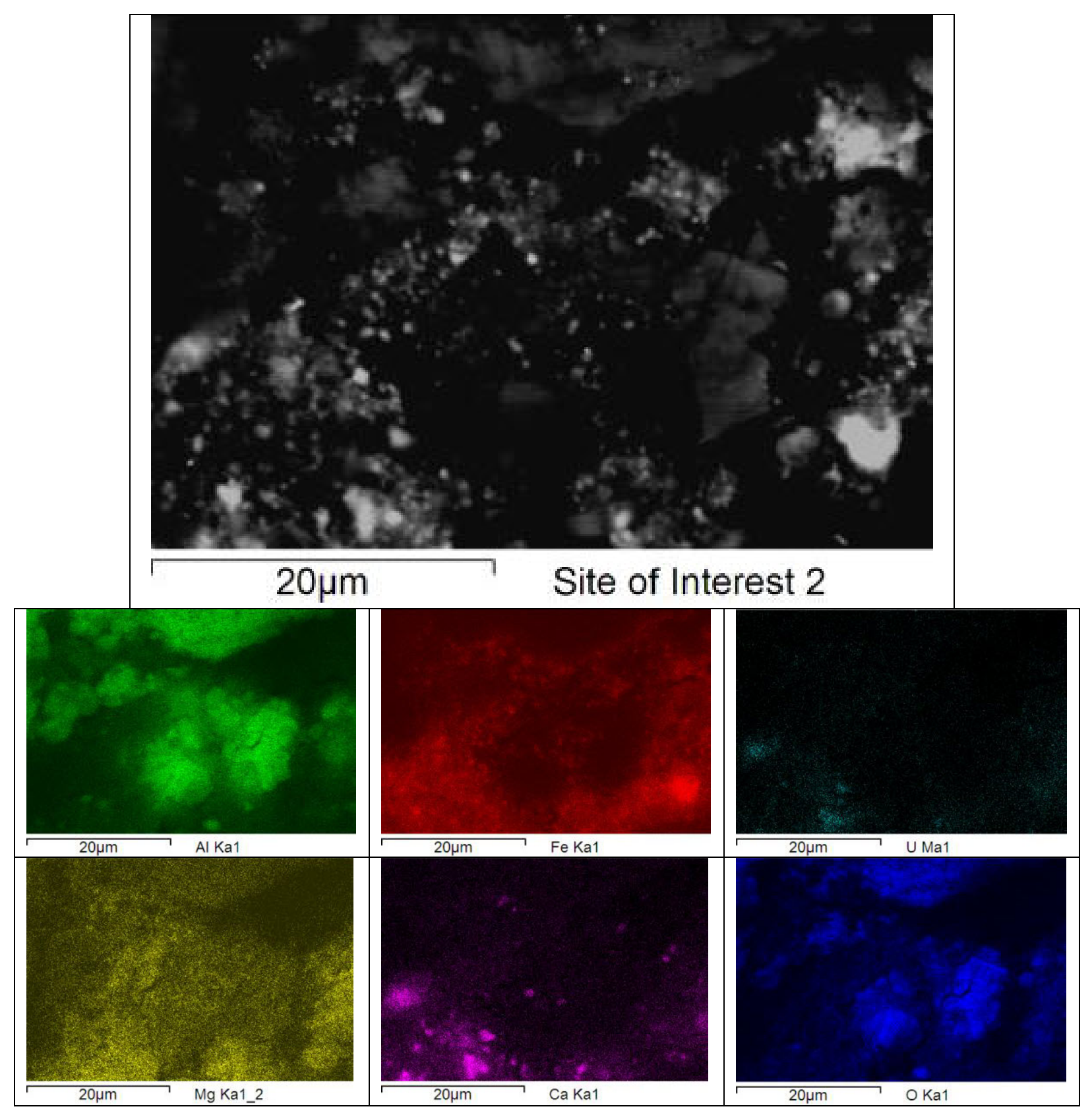

Figure 3-7 Elemental Mapping of Site 2 of FTF-18-1 
SRNL-STI-2012-00123

Revision 0

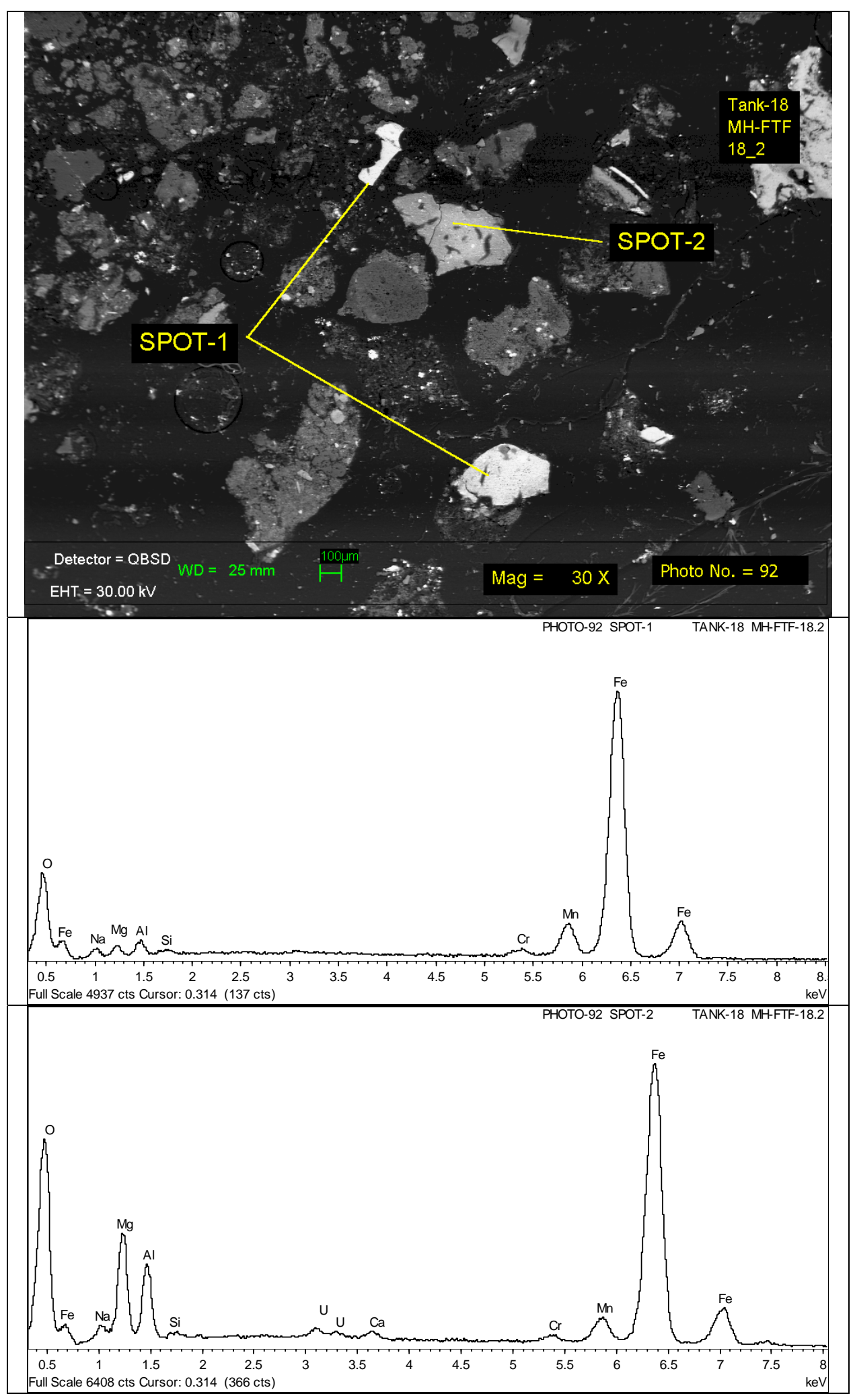

Figure 3-8 Two Iron Oxide Matrices in Tank 18 Sample FTF-18-2 


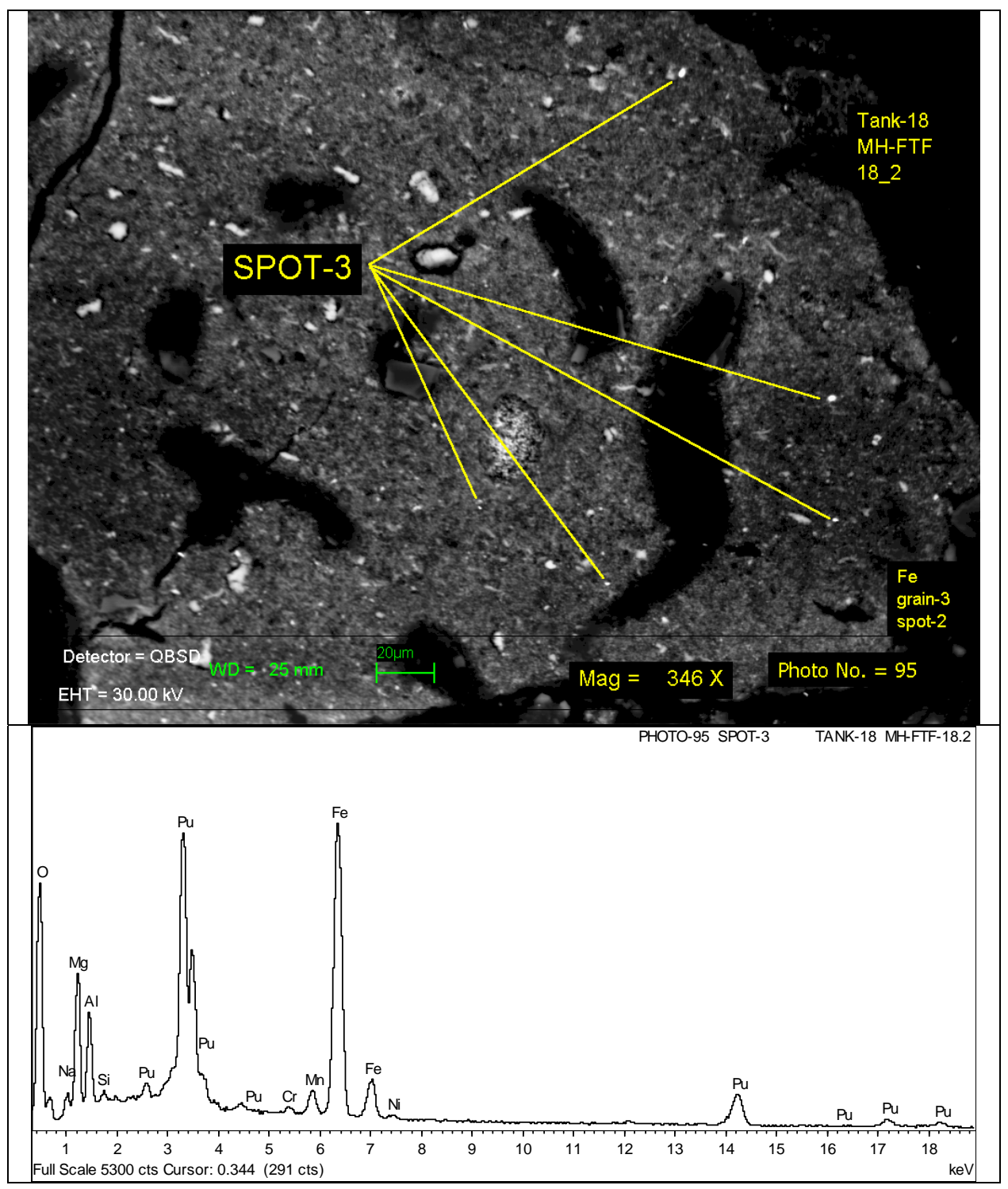

Figure 3-9 Higher Magnification of Porous Iron Oxide Matrix Containing Plutonium Particles in Sample FTF-18-2 


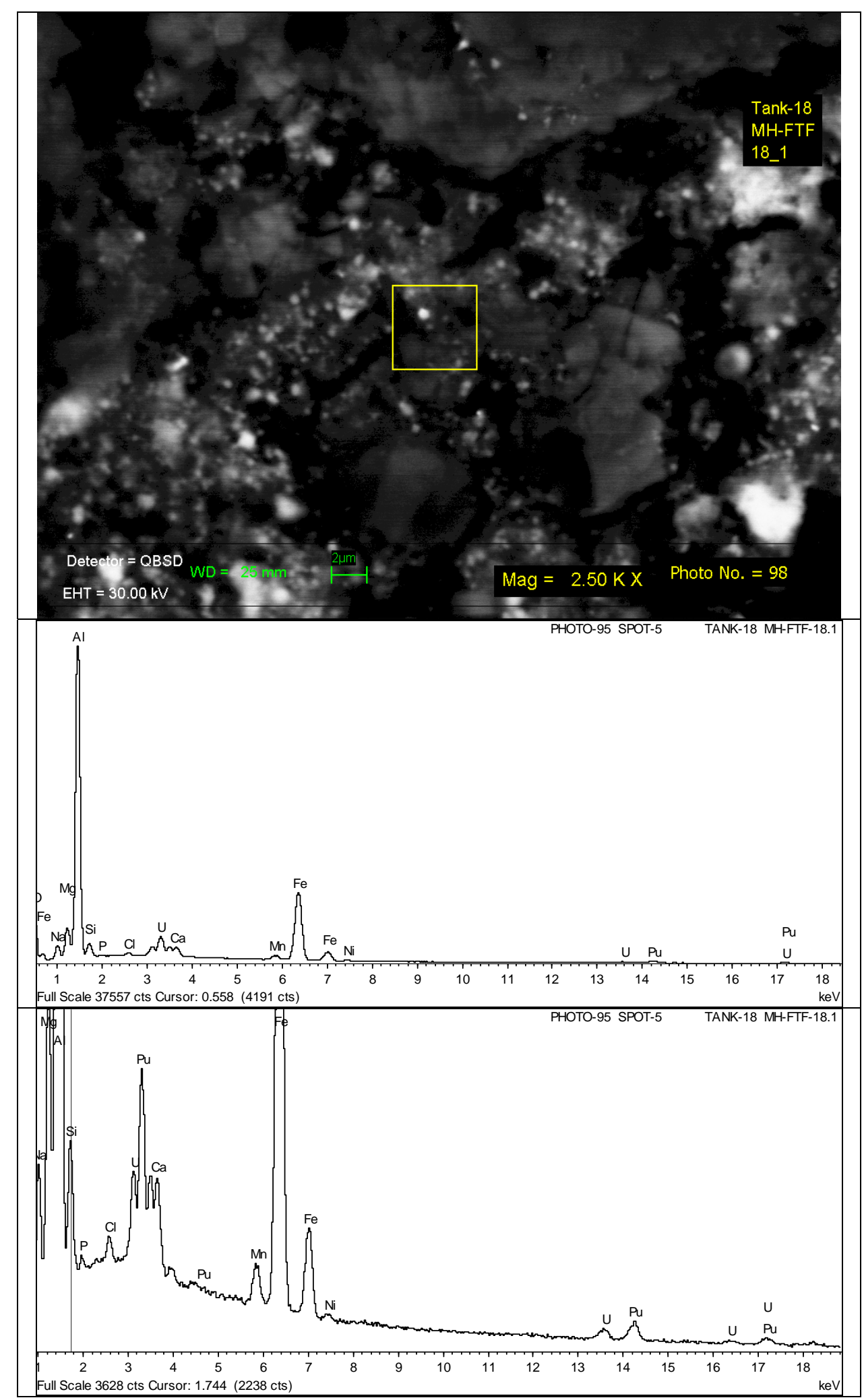

Figure 3-10 Higher Magnification of Porous Iron Oxide Matrix Containing Plutonium Particles in Sample FTF-18-1 


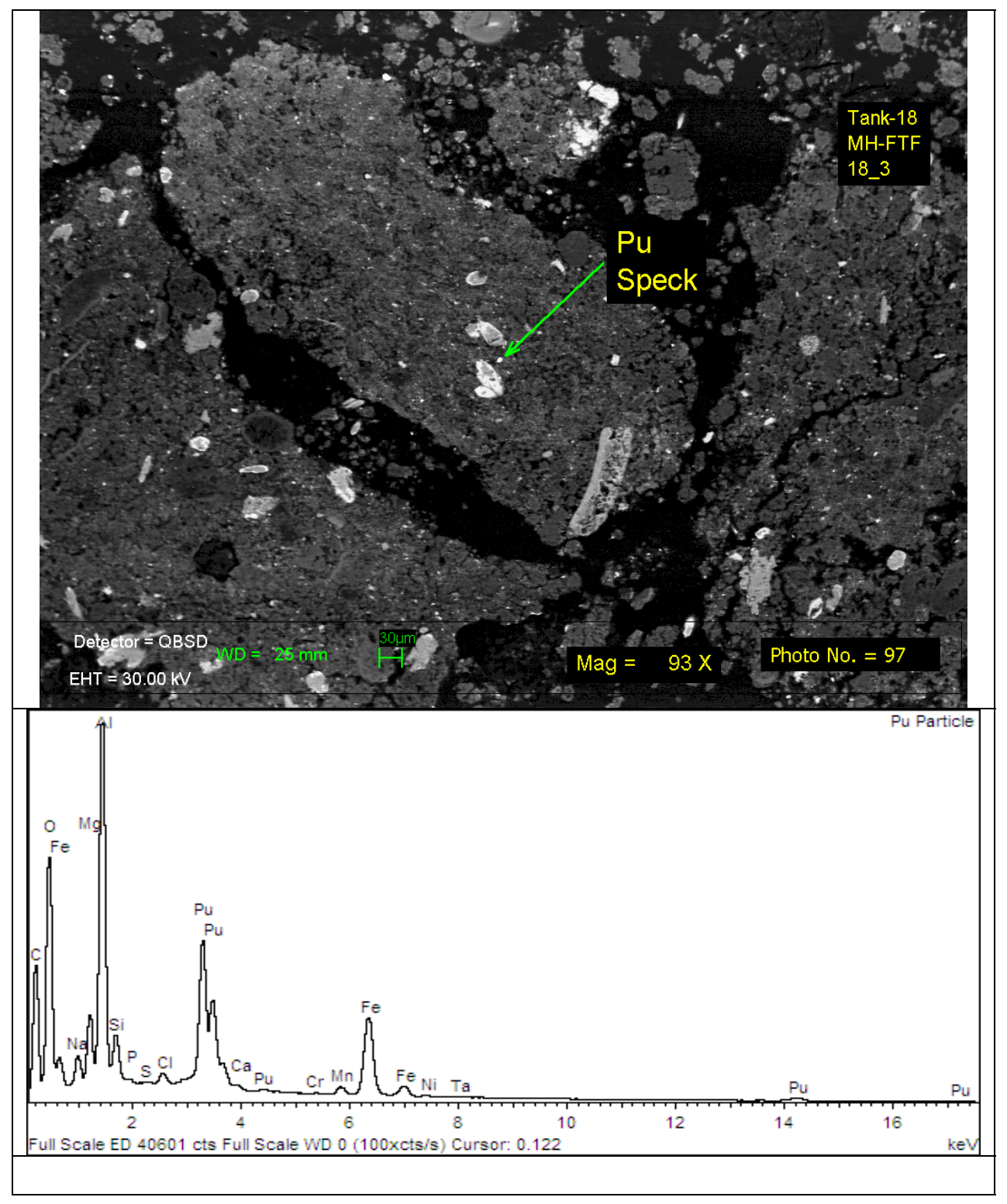

Figure 3-11 Higher Magnification of Porous Iron Oxide Matrix Containing Plutonium Particles in Sample FTF-18-3 


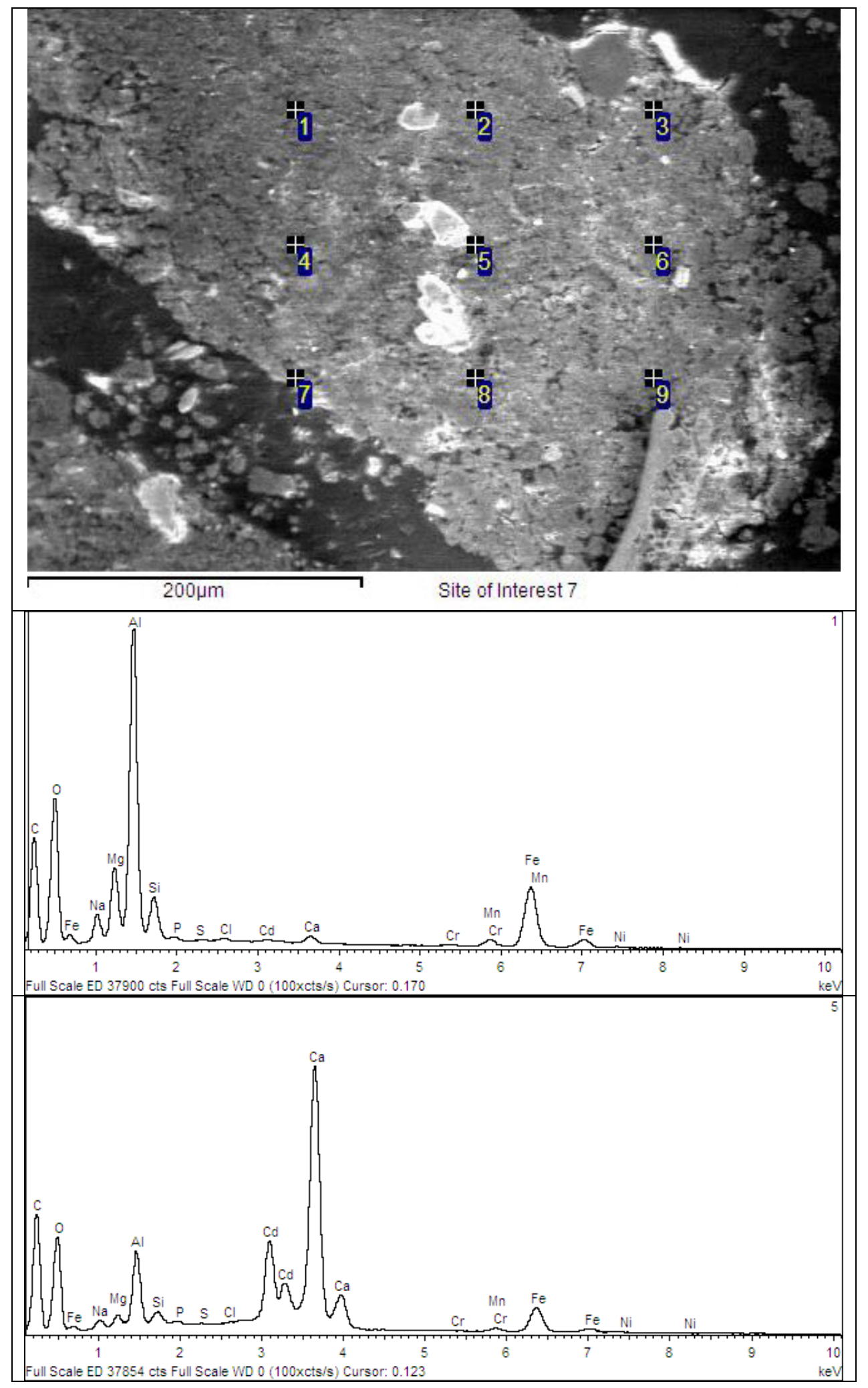

Figure 3-12 Grid Analysis of Matrix Containing Plutonium Particles in Sample FTF-18-3 


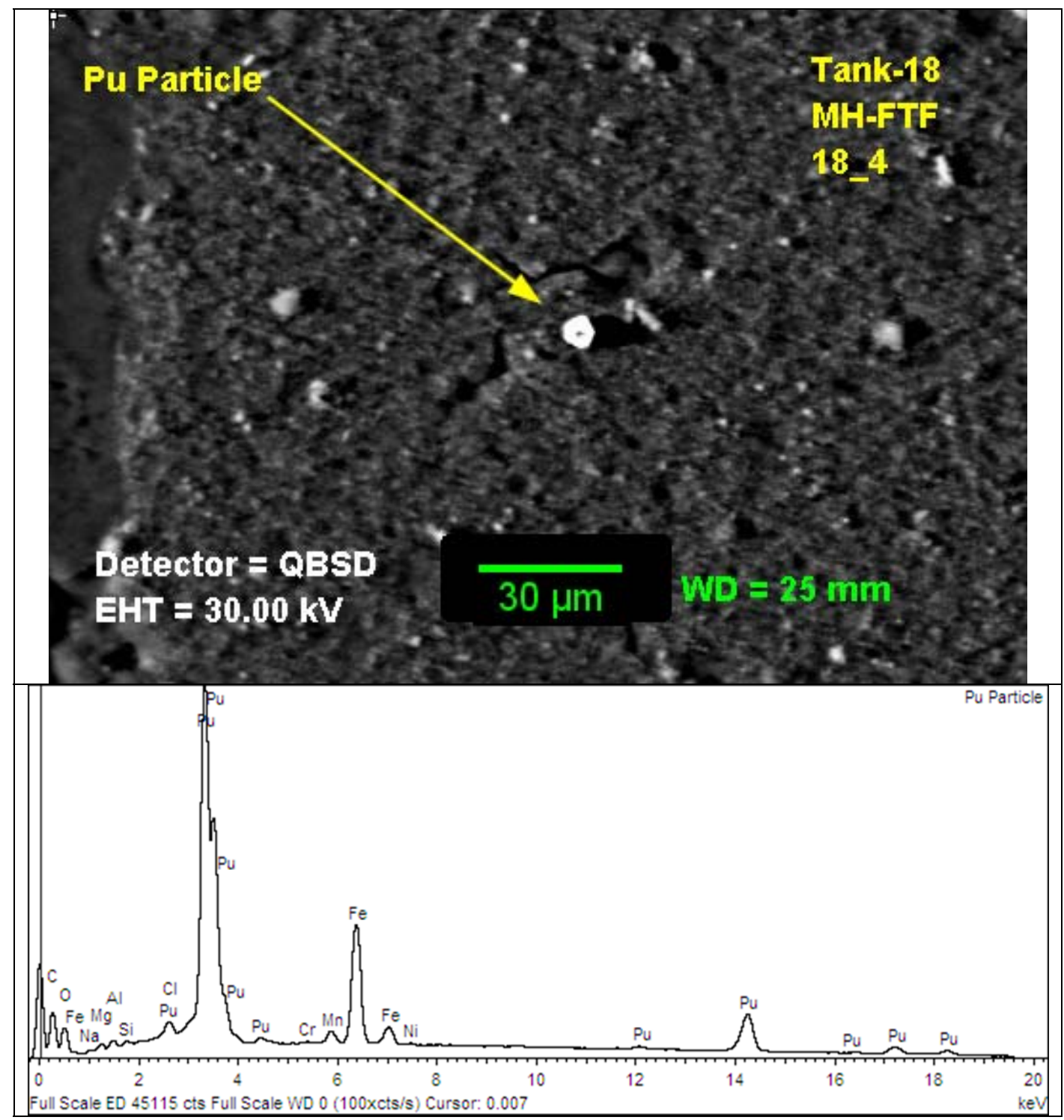

Figure 3-13 Higher Magnification of Porous Iron Oxide Phase Containing Plutonium Particles in Sample FTF-18-4 


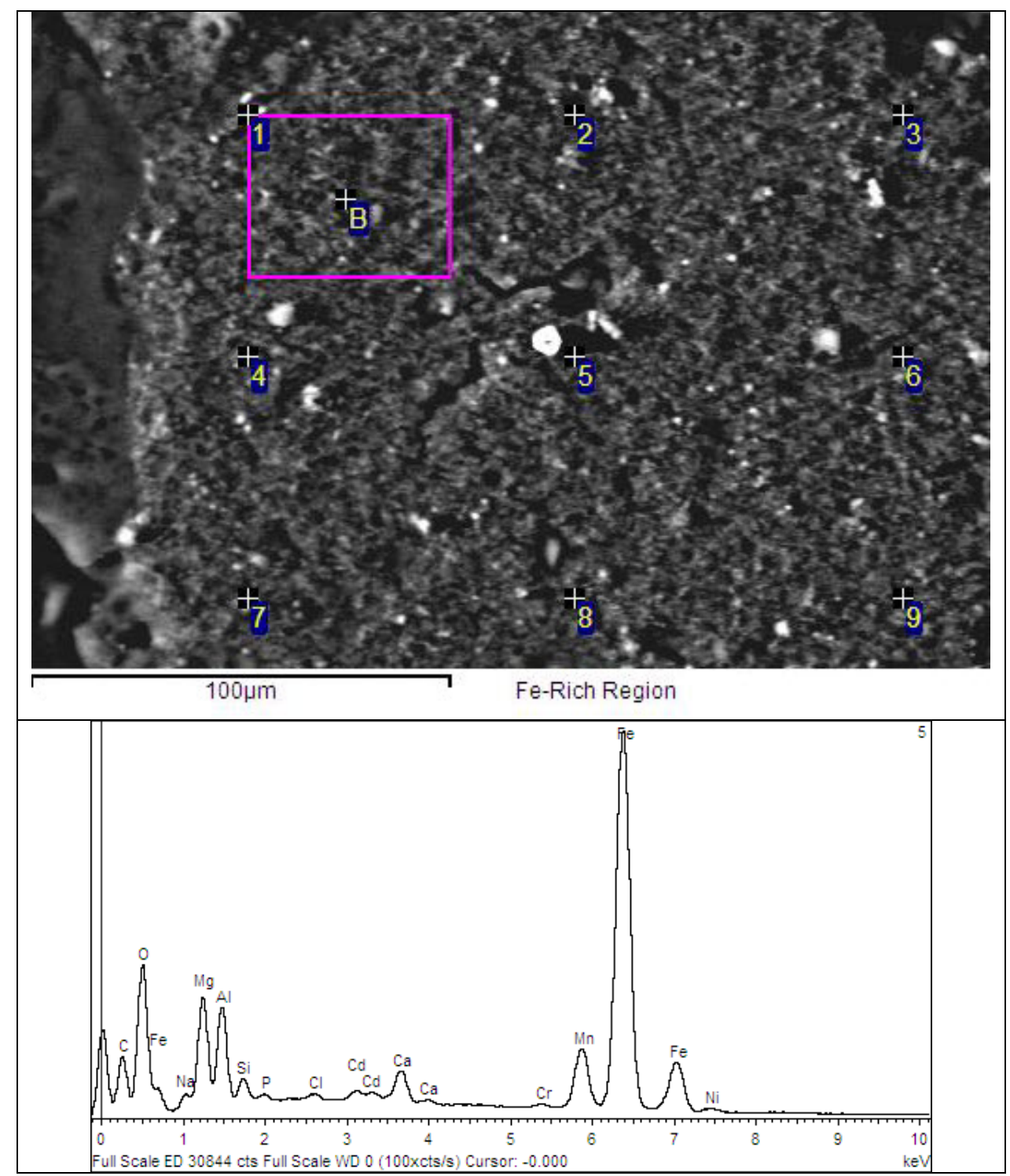

Figure 3-14 Grid Analysis of Matrix Containing Plutonium Particles in Sample FTF-18-4 


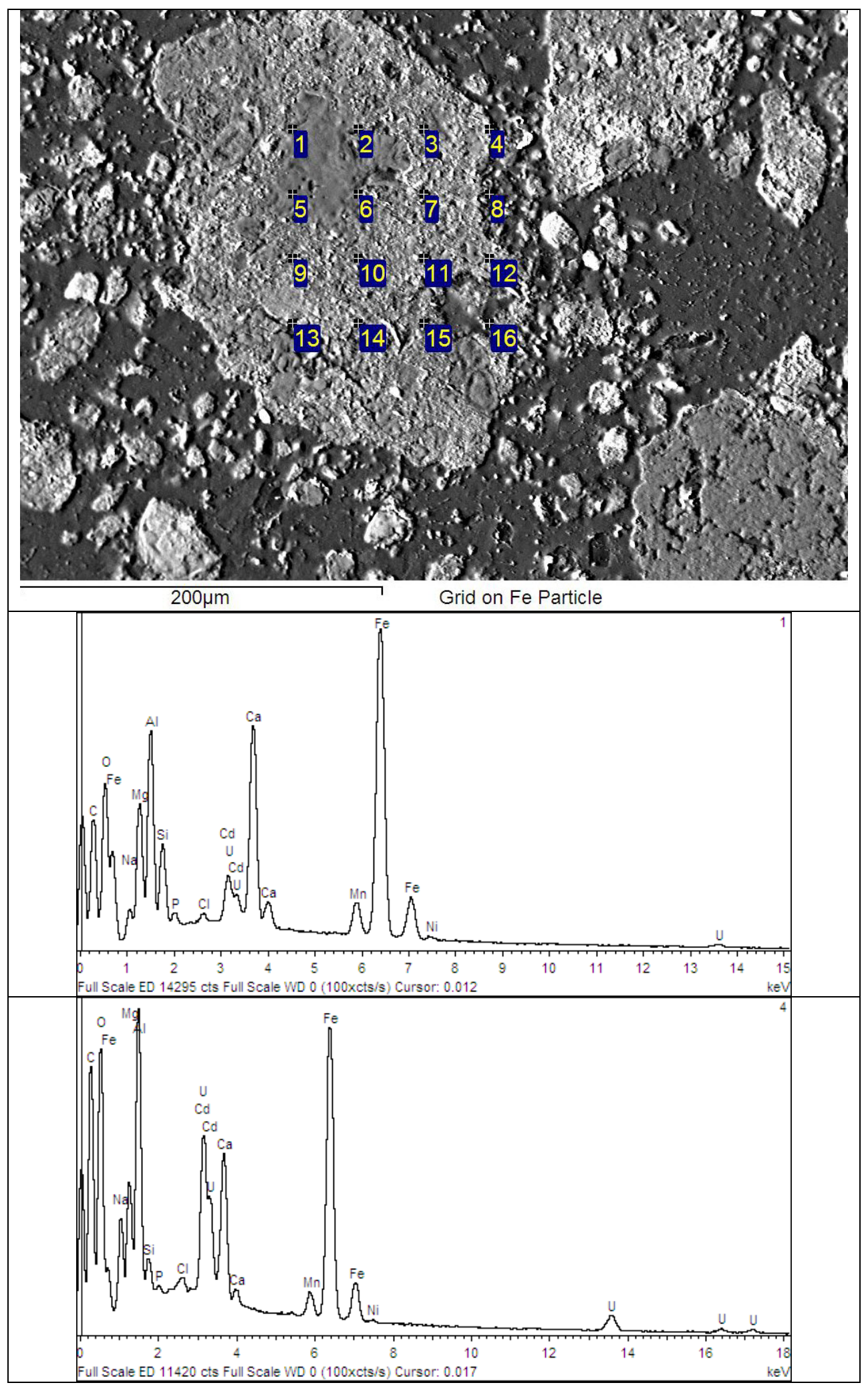

Figure 3-15 WDS Grid Analysis of Matrix Containing Plutonium Particles in Sample FTF-18-1 
SRNL-STI-2012-00123

Revision 0

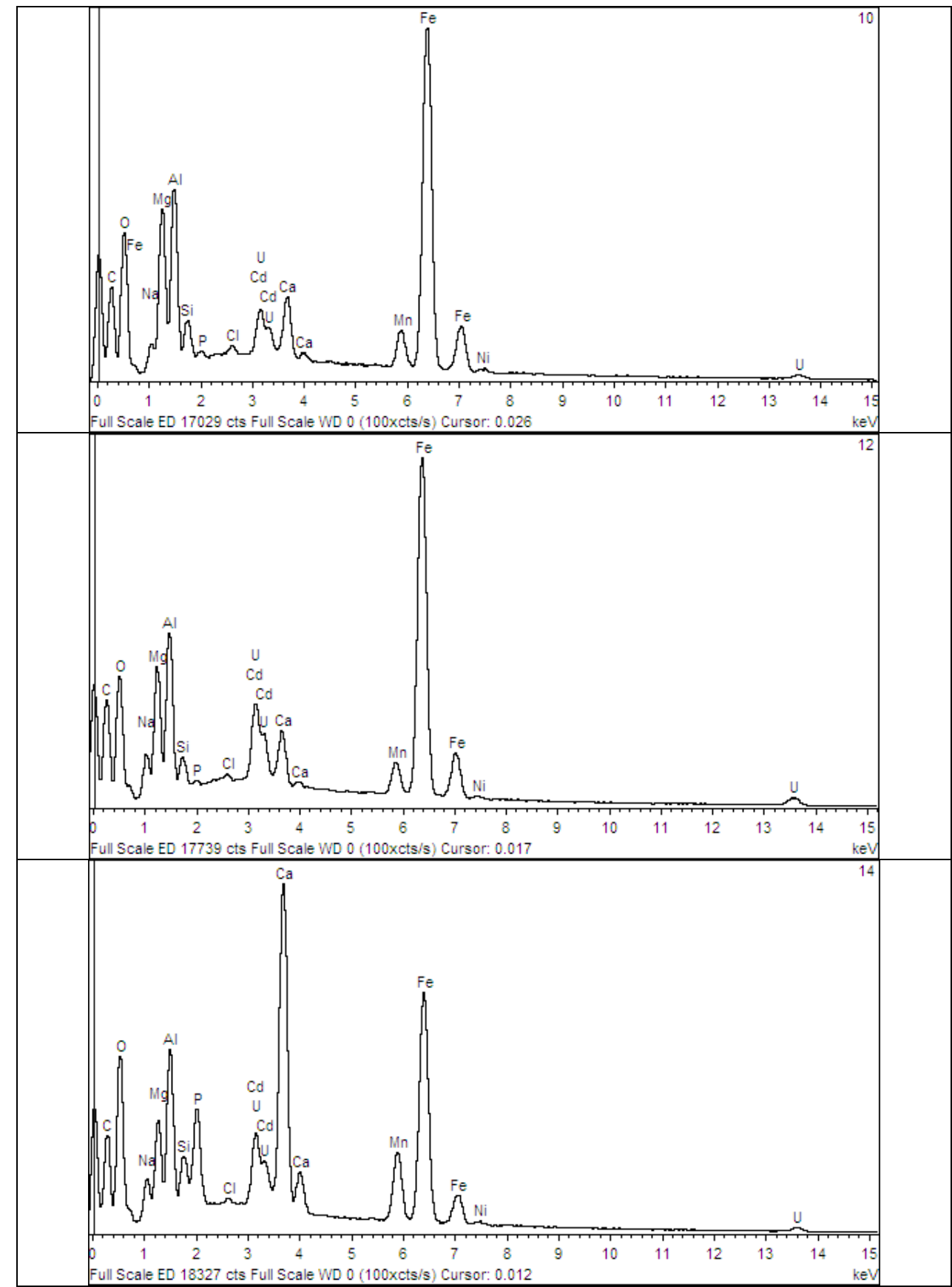

Figure 3-15 WDS Grid Analysis of Matrix Containing Plutonium Particles in Sample FTF-18-1 (continued) 
SRNL-STI-2012-00123

Revision 0

Table 3-3. Spots from Figure 3-15 Found to Contain Plutonium

\begin{tabular}{|c|c|c|c|c|c|c|c|c|c|c|}
\hline \multirow[b]{2}{*}{ Spot } & \multicolumn{9}{|c|}{$\begin{array}{c}\text { EDS } \\
\text { Wt }{ }^{1,2}\end{array}$} & \multirow{2}{*}{$\begin{array}{c}\begin{array}{c}\text { WDS } \\
\text { Wt \% }\end{array} \\
\mathbf{P u}^{3}\end{array}$} \\
\hline & $\mathrm{Na}^{1}$ & $\mathbf{M g}^{1}$ & $\mathbf{A l}^{1}$ & $\mathrm{Si}^{1}$ & $\mathrm{Ca}^{1}$ & $\mathbf{M n}^{1}$ & $\mathrm{Fe}^{1}$ & $\mathbf{U}^{1}$ & $\mathbf{O}^{1,2}$ & \\
\hline 1 & 2.1 & 9.7 & 13 & 5.6 & 6.2 & 2.3 & 20 & 5.2 & 35 & $<$ LOD \\
\hline 2 & 1.5 & 6.1 & 17 & 5.4 & 7.0 & 2.0 & 19 & 5.3 & 36 & $<\mathrm{LOD}$ \\
\hline 3 & 5.3 & 7.8 & 17 & 12.8 & 0.79 & 1.5 & 6.2 & 8.0 & 41 & 0.097 \\
\hline 4 & 7.3 & 7.0 & 15 & 2.2 & 3.8 & 1.4 & 16 & 15 & 32 & 0.19 \\
\hline 5 & 0.0 & 3.6 & 21 & 2.3 & 1.5 & 2.3 & 32 & 3.7 & 34 & $<$ LOD \\
\hline 6 & 0.10 & 7.9 & 13 & 2.4 & 3.3 & 3.8 & 32 & 4.4 & 32 & $<$ LOD \\
\hline 7 & 5.4 & 6.9 & 6.6 & 1.6 & 1.2 & 1.6 & 13 & 37 & 26 & $<$ LOD \\
\hline 8 & 5.7 & 7.4 & 15 & 7.1 & 2.9 & 2.9 & 12 & 9.8 & 36 & 0.073 \\
\hline 9 & 2.6 & 5.9 & 12 & 2.1 & 9.1 & 2.2 & 25 & 8.4 & 31 & $<\mathrm{LOD}$ \\
\hline 10 & 2.0 & 13 & 13 & 3.3 & 2.1 & 2.7 & 24 & 5.3 & 34 & 0.082 \\
\hline 11 & 1.0 & 16 & 22 & 2.6 & 1.4 & 1.1 & 11 & 5.8 & 39 & 0.11 \\
\hline 12 & 4.5 & 11 & 12 & 2.5 & 1.7 & 2.4 & 24 & 9.6 & 32 & 0.14 \\
\hline 13 & 4.8 & 6.7 & 14 & 6.6 & 1.6 & 2.3 & 19 & 9.2 & 35 & $<\mathrm{LOD}$ \\
\hline 14 & 4.5 & 7.6 & 11 & 3.2 & 11 & 4.8 & 16 & 8.6 & 32 & 0.13 \\
\hline 15 & 2.3 & 11 & 16 & 5.0 & 3.7 & 1.9 & 19 & 4.8 & 36 & $<$ LOD \\
\hline 16 & 4.6 & 4.2 & 26 & 2.2 & 0.91 & 1.4 & 17 & 6.7 & 37 & $<\mathrm{LOD}$ \\
\hline
\end{tabular}

${ }^{1}$ EDS numerical results are for trend analysis only and are normalized to $100 \%$. EDS results are semiquantitative estimates based on standardless analysis and theoretical intensity corrections from Oxford Instruments INCA 4.15 EDS software.

${ }^{2}$ Oxygen calculated by stoichiometry, assuming $\mathrm{Na}_{2} \mathrm{O}, \mathrm{MgO}, \mathrm{Al}_{2} \mathrm{O}_{3}, \mathrm{SiO}_{2}, \mathrm{CaO}, \mathrm{MnO}, \mathrm{Fe}_{2} \mathrm{O}_{3}, \mathrm{UO}_{2} . \mathrm{Pu}$ is not included in the oxygen calculation.

${ }^{3} \mathrm{Pu}$ Limit of Detection (LOD) is $\sim 0.04 \mathrm{wt} \%$ based on 3 -sigma counting statistics. Pu estimated uncertainty $+/-30 \%$ for values $<0.1 \mathrm{wt} \%$ based on 2 -sigma counting statistics. 
SRNL-STI-2012-00123

Revision 0

\subsection{Conclusions}

XRD analysis of the Tank 18 samples did not identify any plutonium mineral phases in the samples. These indicates the crystalline mineral phases of plutonium are below the detection limits of the XRD method or that the plutonium phase(s) lack long range order and are present as amorphous or microcrystalline solids.

SEM analysis of the Tank 18 samples did locate particles containing plutonium. The plutonium was found as small particles, usually $<1 \mu \mathrm{m}$ but ranging up to several micrometers in diameter, associated with particles of an iron matrix and at low concentration in other elemental matrices. This suggests the plutonium has an affinity for the iron matrix. Qualitatively, the particles of plutonium found in the SEM analysis do not appear to account for all of the plutonium in the sample based on concentrations determined from the chemical analysis of the Tank18 samples. This suggests that plutonium is also distributed throughout the solids in low concentrations.

There are additional methods that could be used to obtain more information about the speciation of the plutonium in the Tank 18 samples. X-ray absorption spectroscopy can potentially provide information about the oxidation state and local coordination environment around the plutonium. Leaching and solubility tests might also provide information about the plutonium speciation. 
SRNL-STI-2012-00123

Revision 0

\subsection{References}

1. M. S. Hay, "Task Technical and Quality Assurance Plan for the Analysis of Plutonium Speciation in Tank 18 Samples", SRNL-RP-2011-01665, Rev. 0, December 14, 2011.

2. TTR, HLE-TTR-2011-020, M Layton-initiator. December 13, 2011.

3. L. N. Oji, D. Diprete, C. J. Coleman, "Characterization of Additional Tank 18F Samples”. SRNL-STI-2010-00386, Rev. 0, September 2, 2010.

4. W. D. King, M. S. Hay, "Alternative Enhanced Chemical Cleaning: Basic Studies Result FY09”, SRNL-STI-2009-00791, February 2010.

5. M. S. Hay, D.R. Click, D. P. Diprete, C. C. Diprete, "Characterization of Tank 18 F Wall and Scale Samples”, SRNL-STI-2009-00802, March 2010.

6. D. T. Hobbs, "Form and Aging of Plutonium in Savannah River Site Waste Tank 18”, SRNL-STI-2009-00791, February 2012. 
SRNL-STI-2012-00123

Revision 0

Appendix A 
SRNL-STI-2012-00123

Revision 0

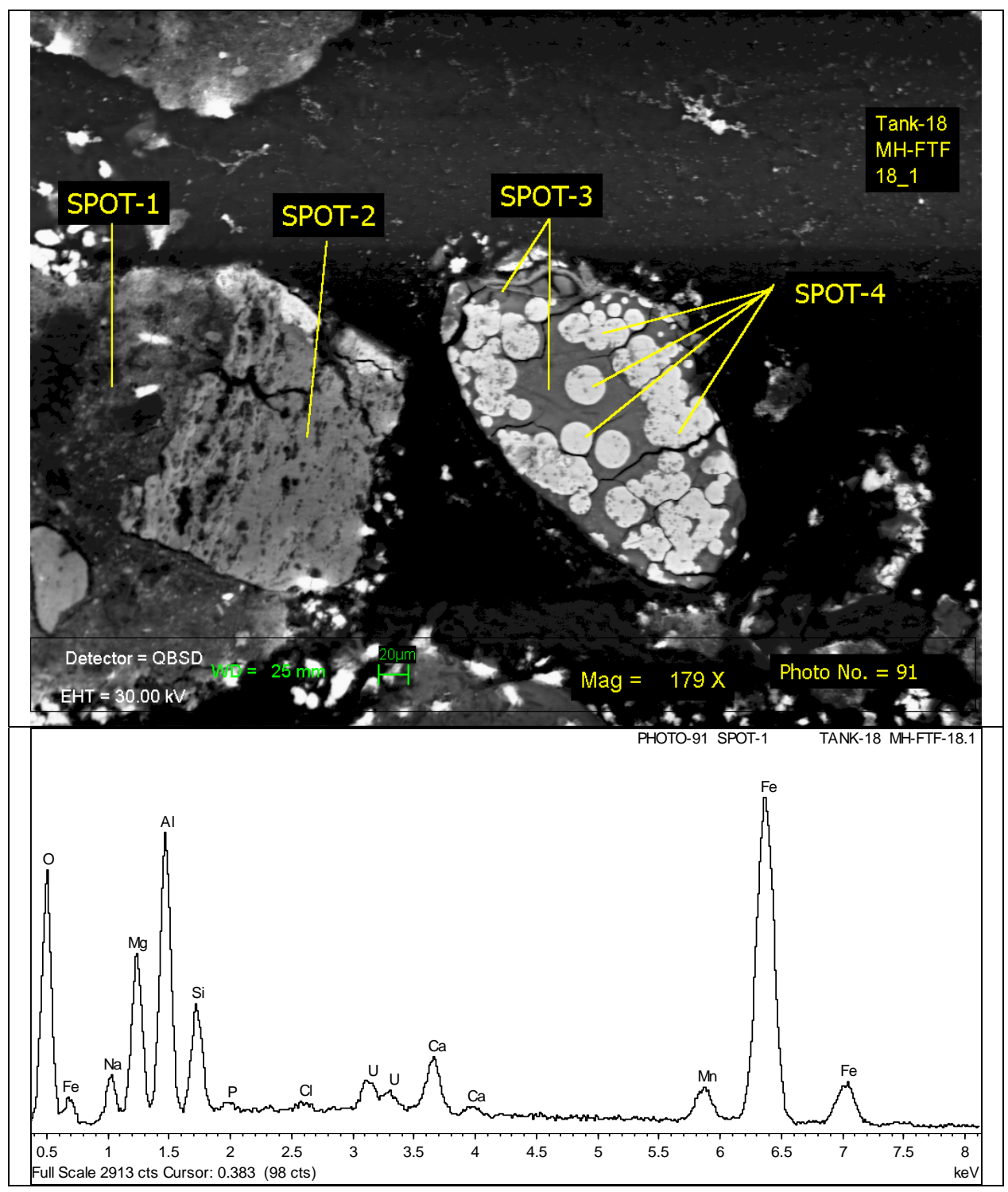

Figure A-1 Micrographs and Spectra of Spots on Particles in Sample FTF-18-1 
SRNL-STI-2012-00123

Revision 0

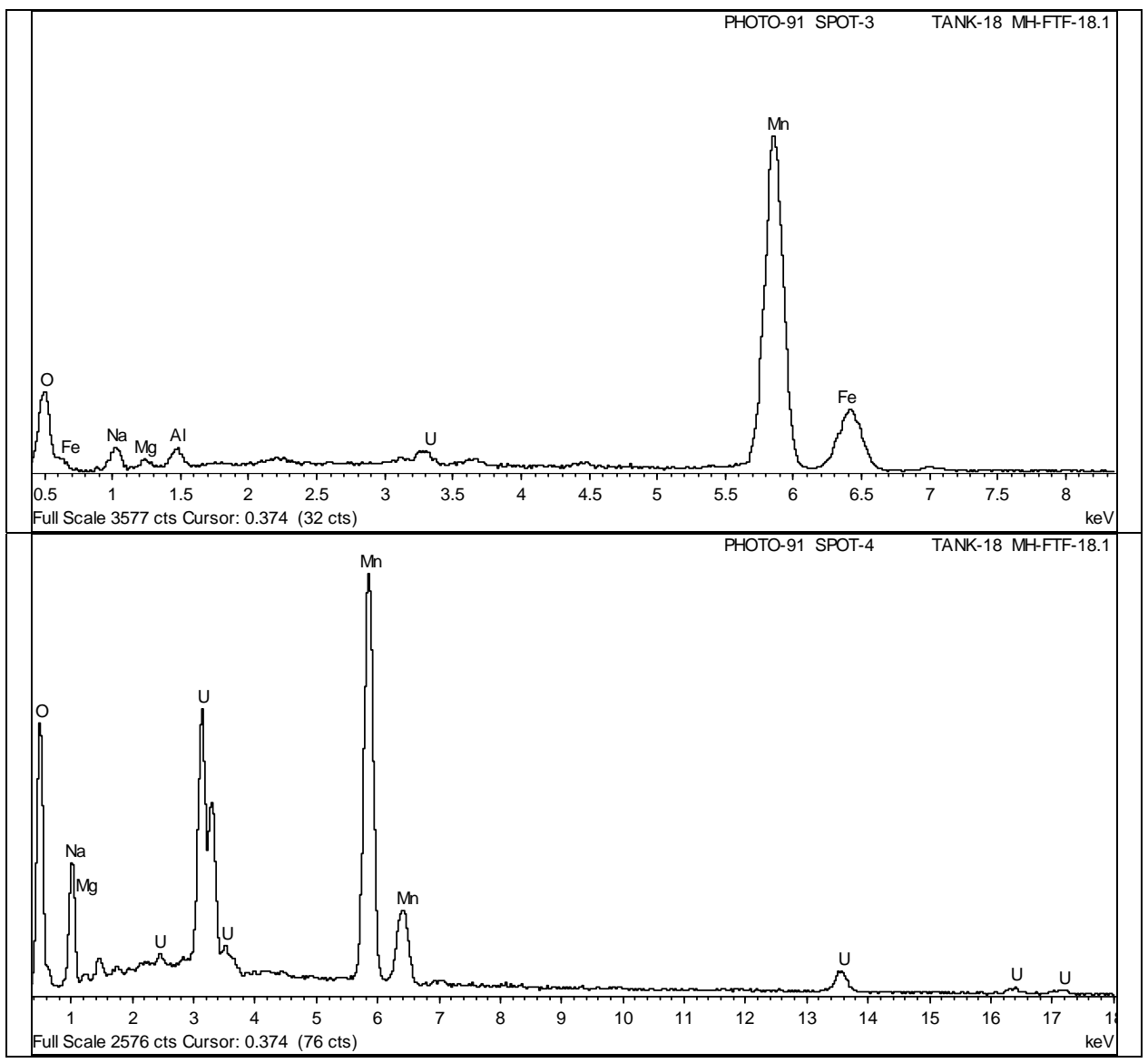

Figure A-1 Micrographs and Spectra of Spots on Particles in Sample FTF-18-1 (continued) 


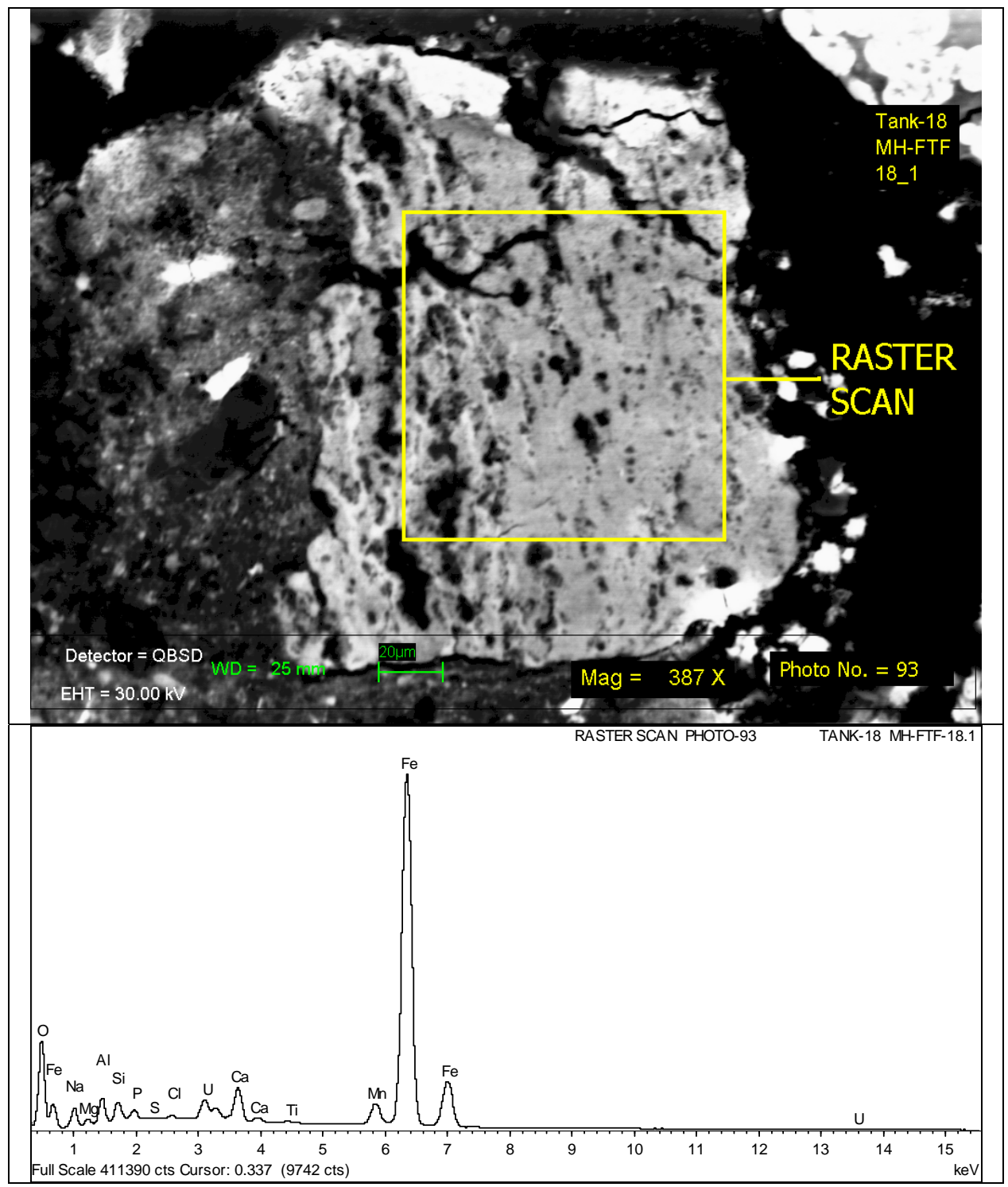

Figure A-2 Micrographs and Spectra of Spots on Particles in Sample FTF-18-1 


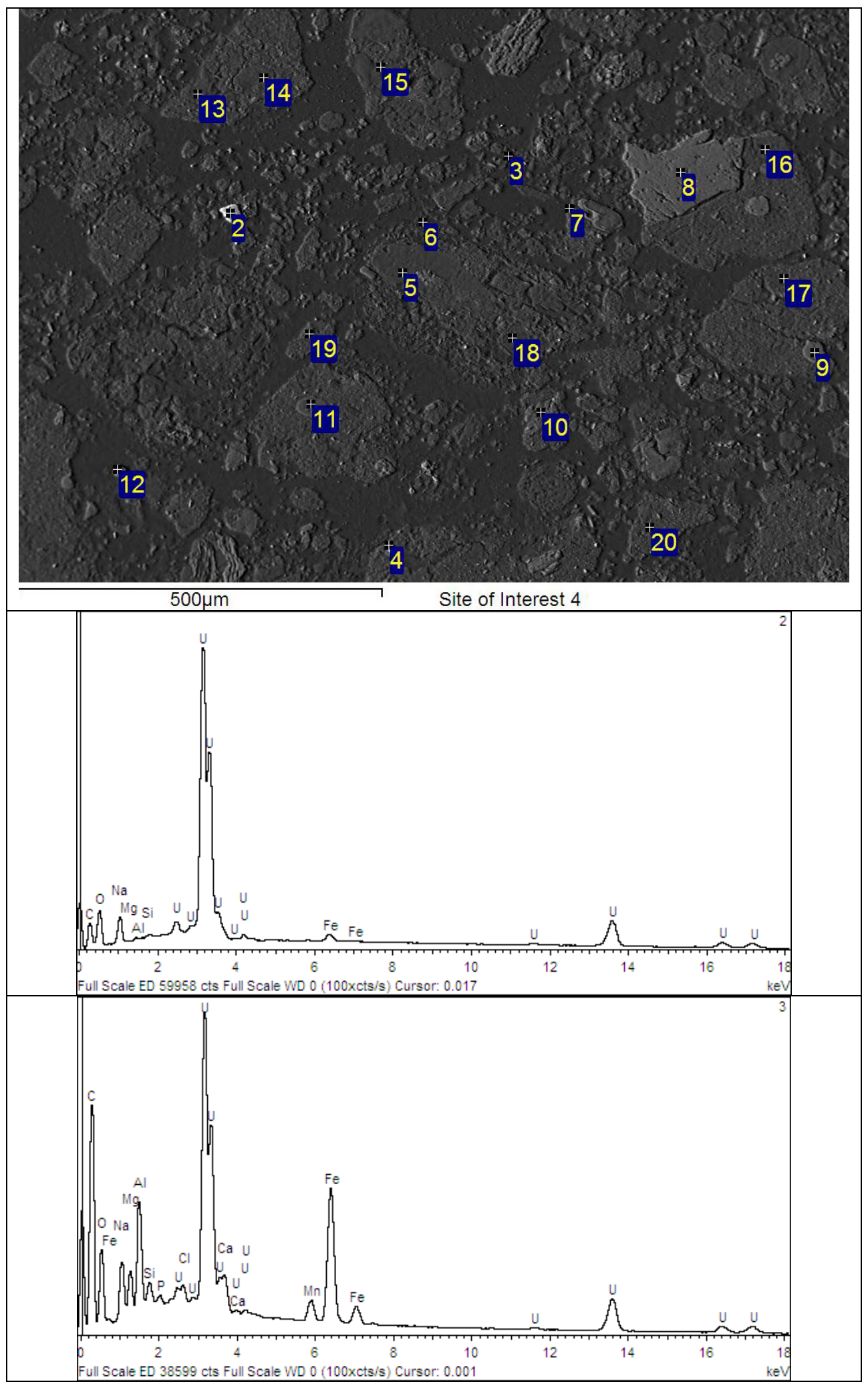

Figure A-3 Micrographs and Spectra of Spots on Particles in Sample FTF-18-1 
SRNL-STI-2012-00123

Revision 0

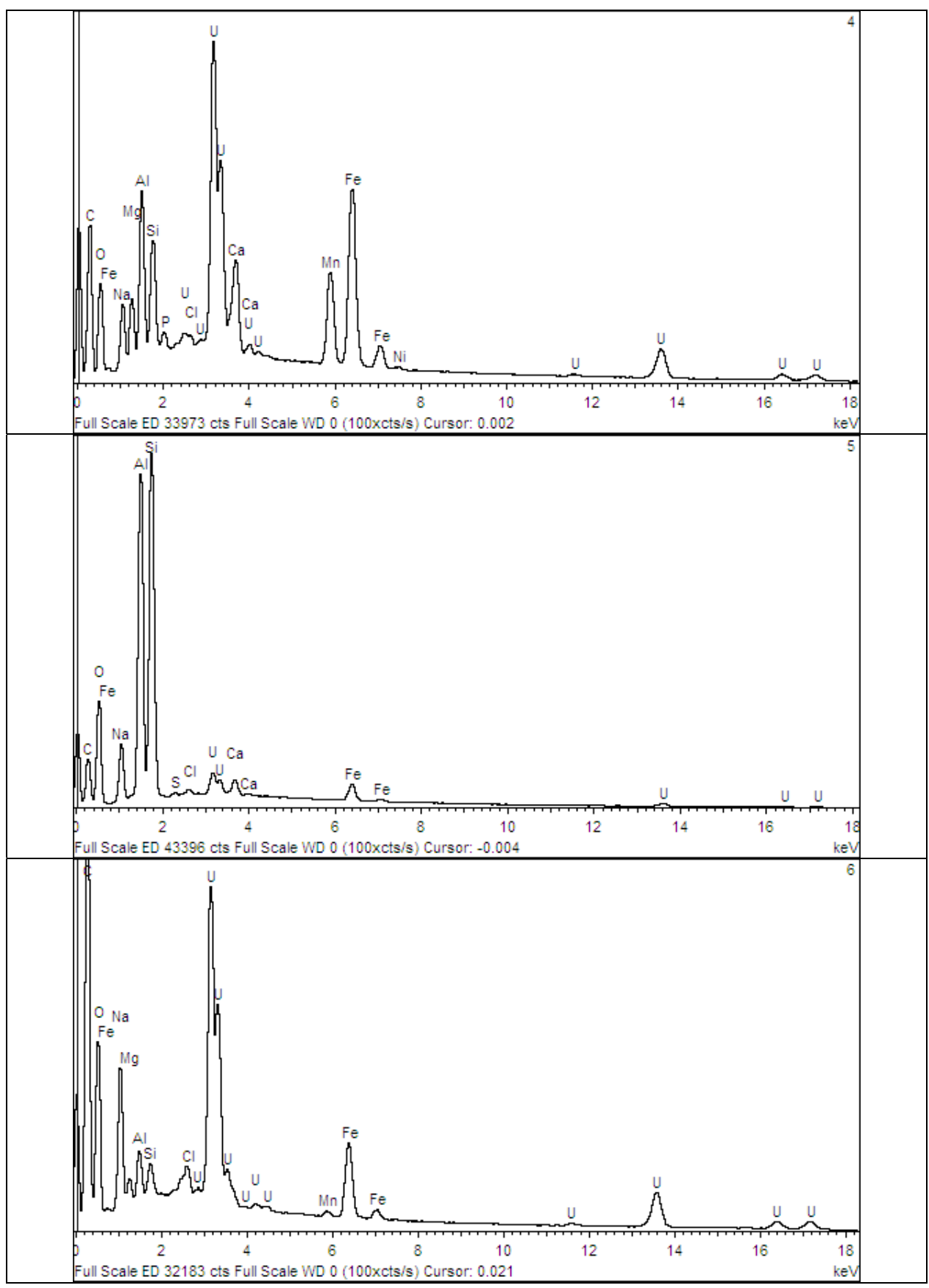

Figure A-3 Micrographs and Spectra of Spots on Particles in Sample FTF-18-1 (continued) 
SRNL-STI-2012-00123

Revision 0

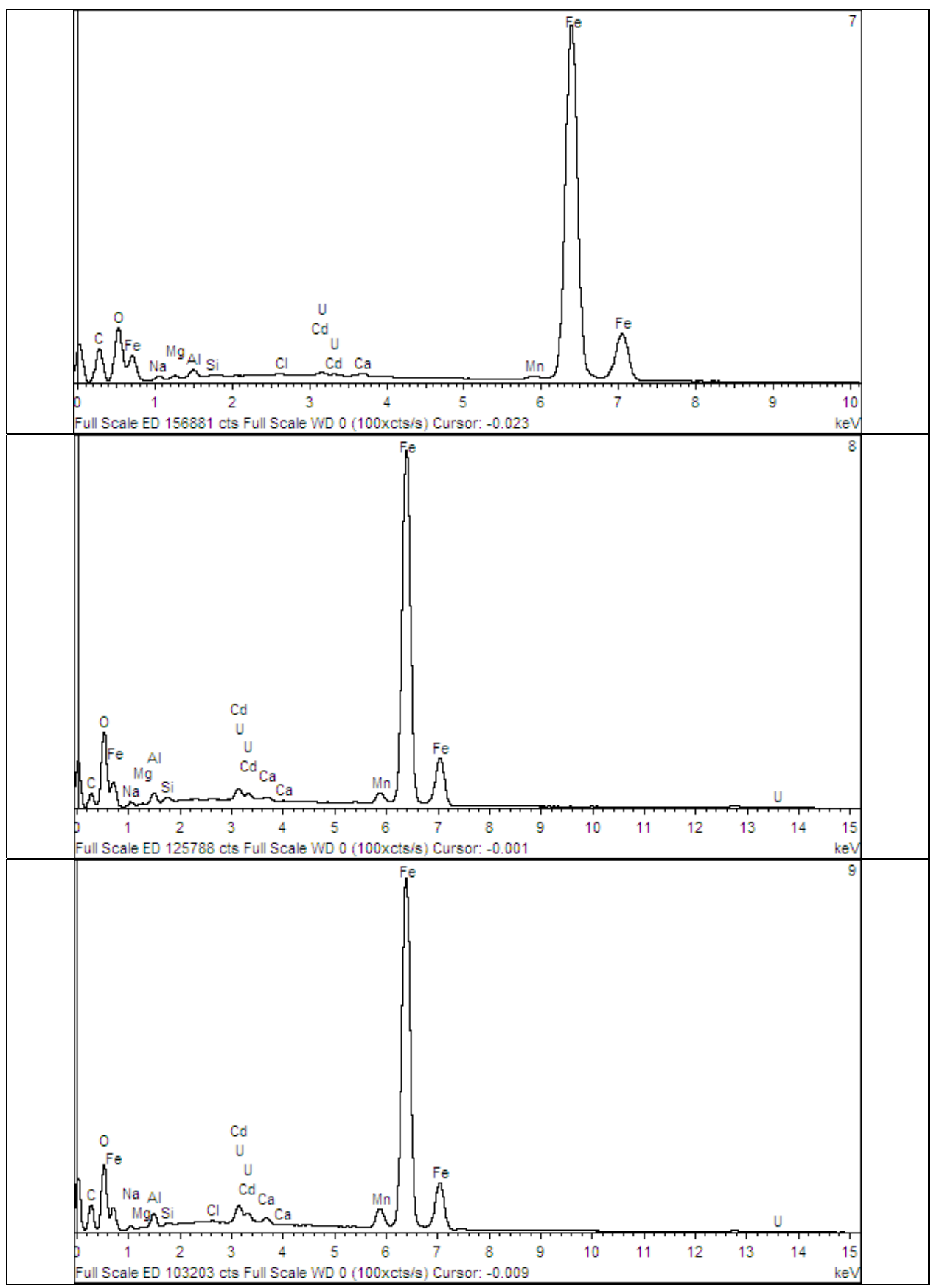

Figure A-3 Micrographs and Spectra of Spots on Particles in Sample FTF-18-1 (continued) 
SRNL-STI-2012-00123

Revision 0

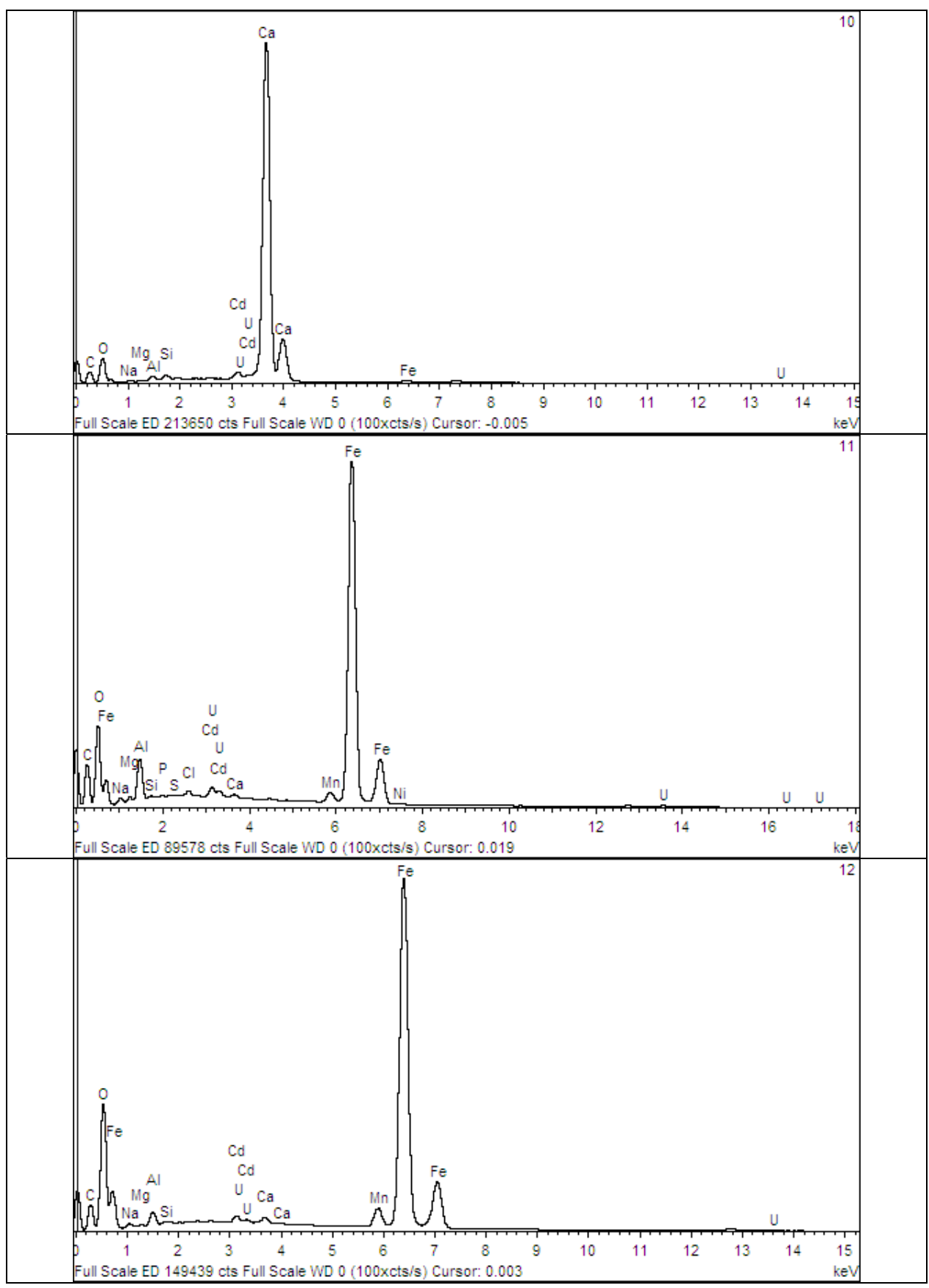

Figure A-3 Micrographs and Spectra of Spots on Particles in Sample FTF-18-1 (continued) 
SRNL-STI-2012-00123

Revision 0

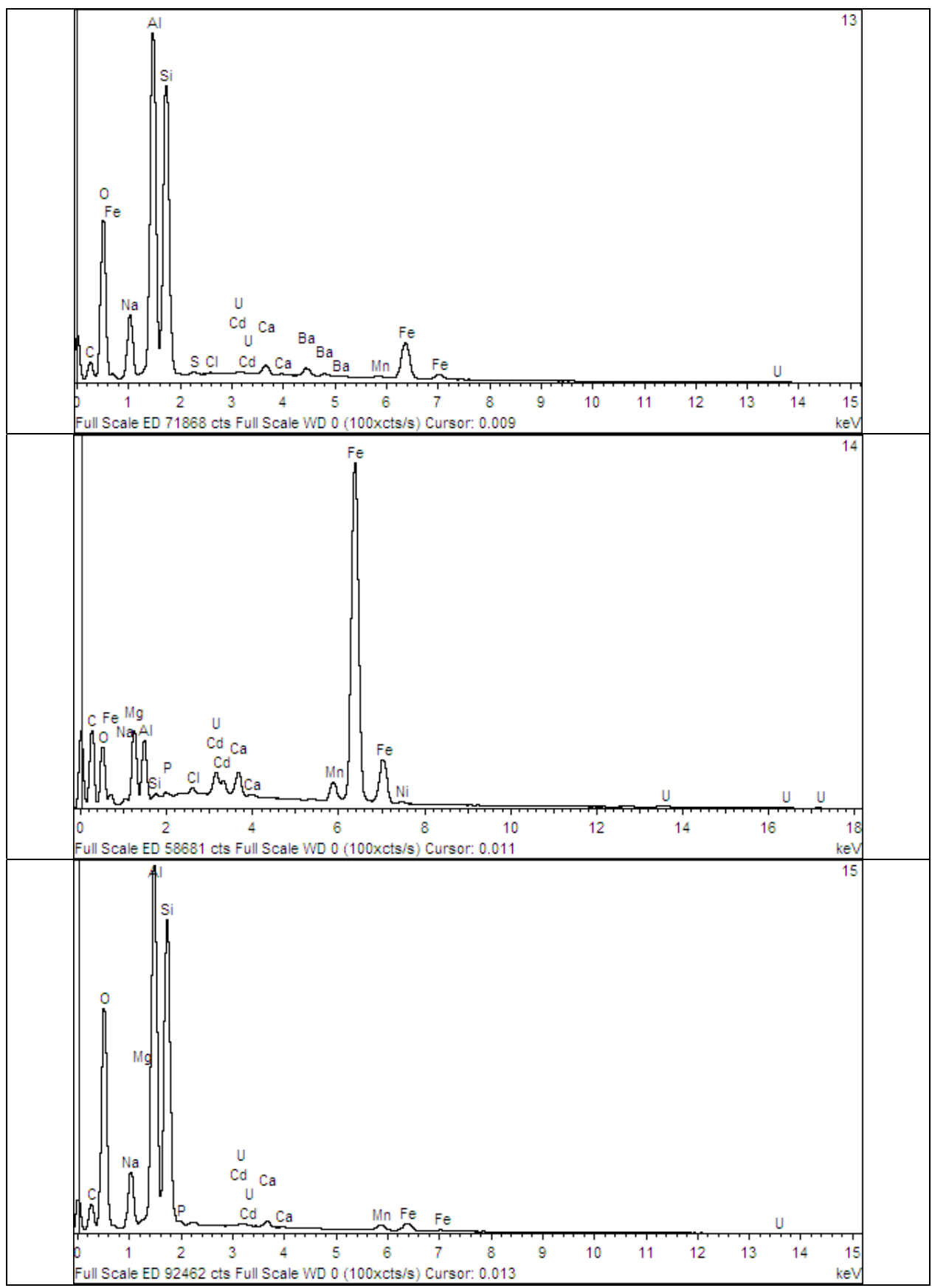

Figure A-3 Micrographs and Spectra of Spots on Particles in Sample FTF-18-1 (continued) 
SRNL-STI-2012-00123

Revision 0

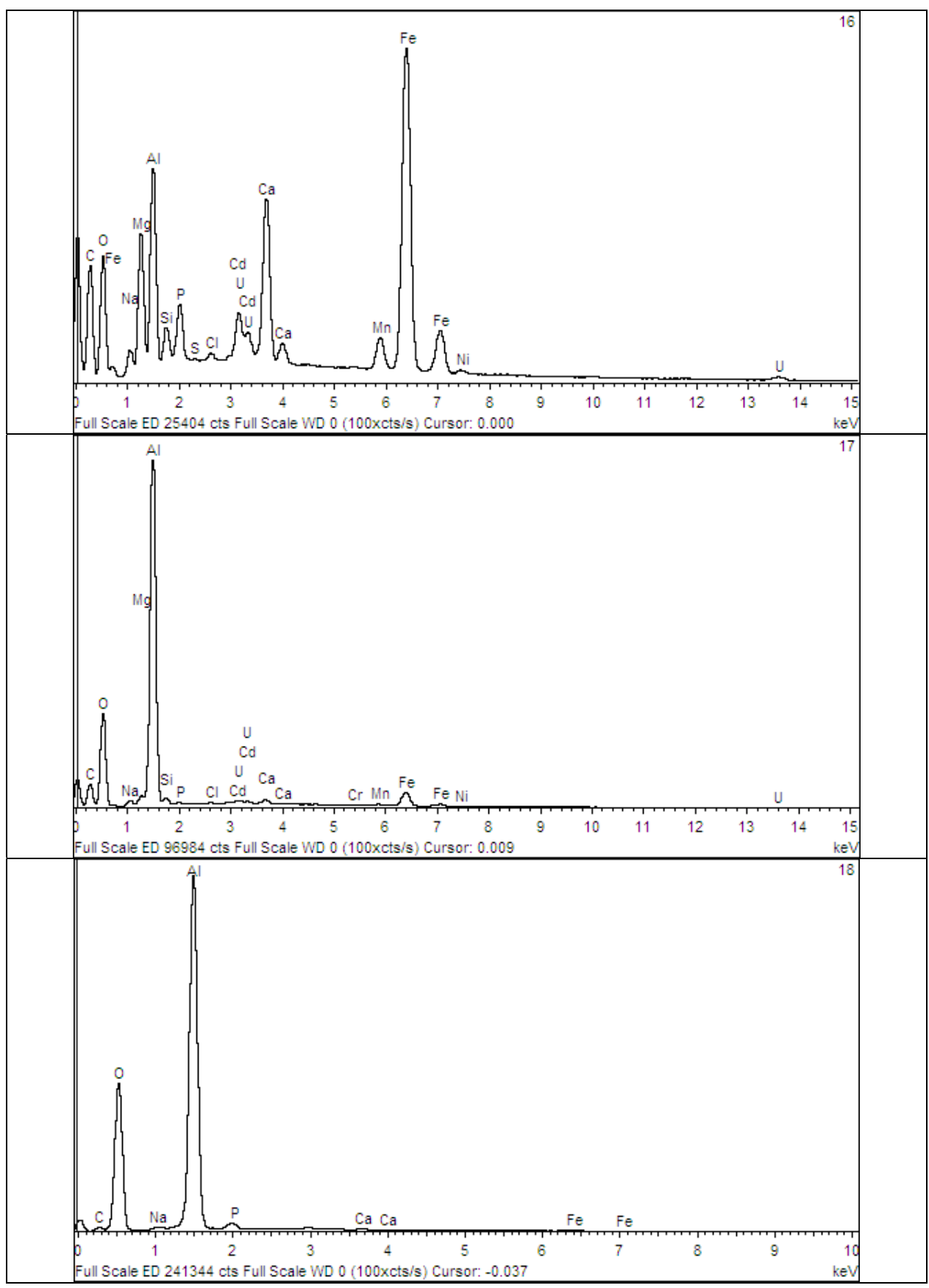

Figure A-3 Micrographs and Spectra of Spots on Particles in Sample FTF-18-1 (continued) 
SRNL-STI-2012-00123

Revision 0

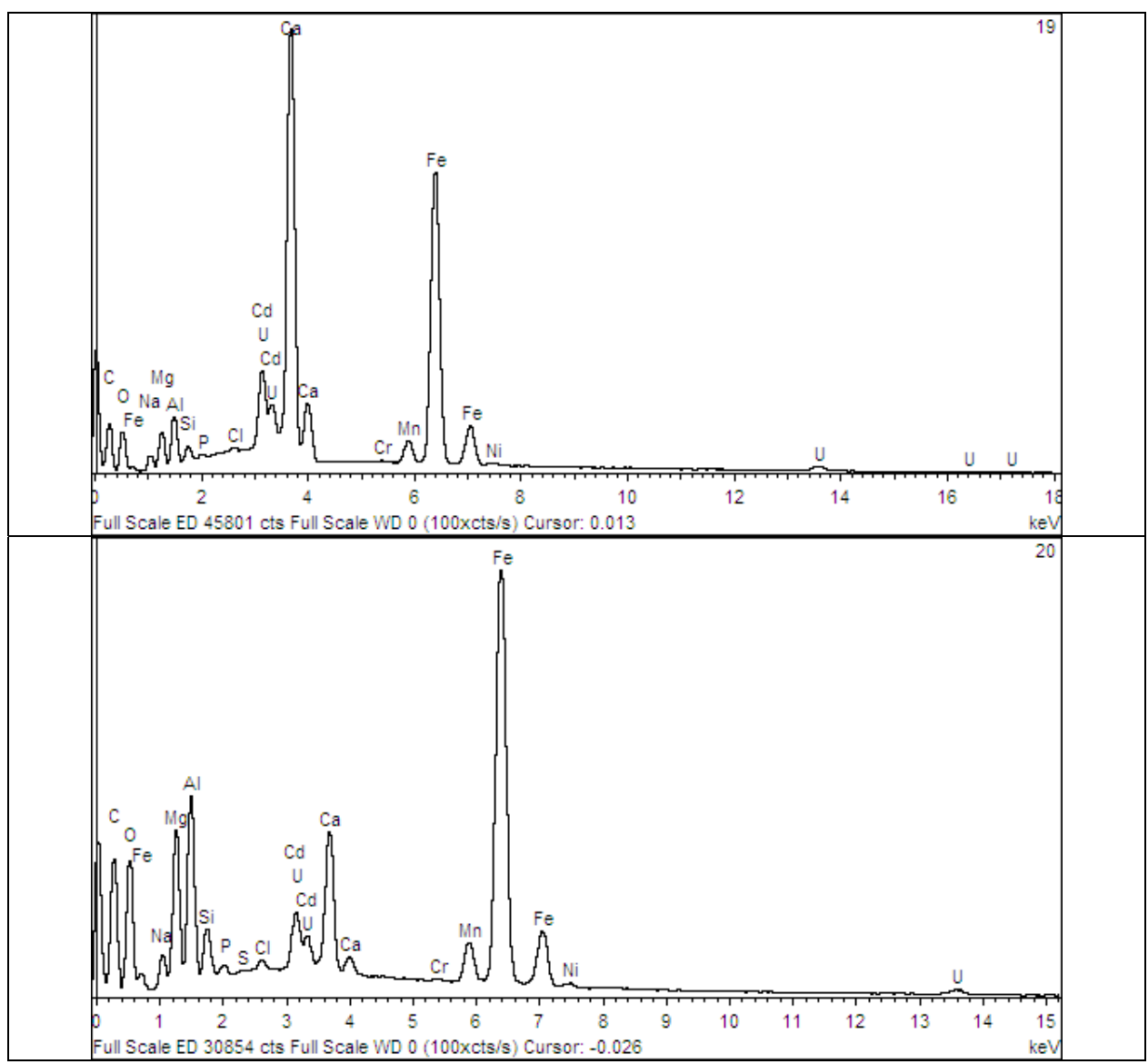

Figure A-3 Micrographs and Spectra of Spots on Particles in Sample FTF-18-1 (continued) 


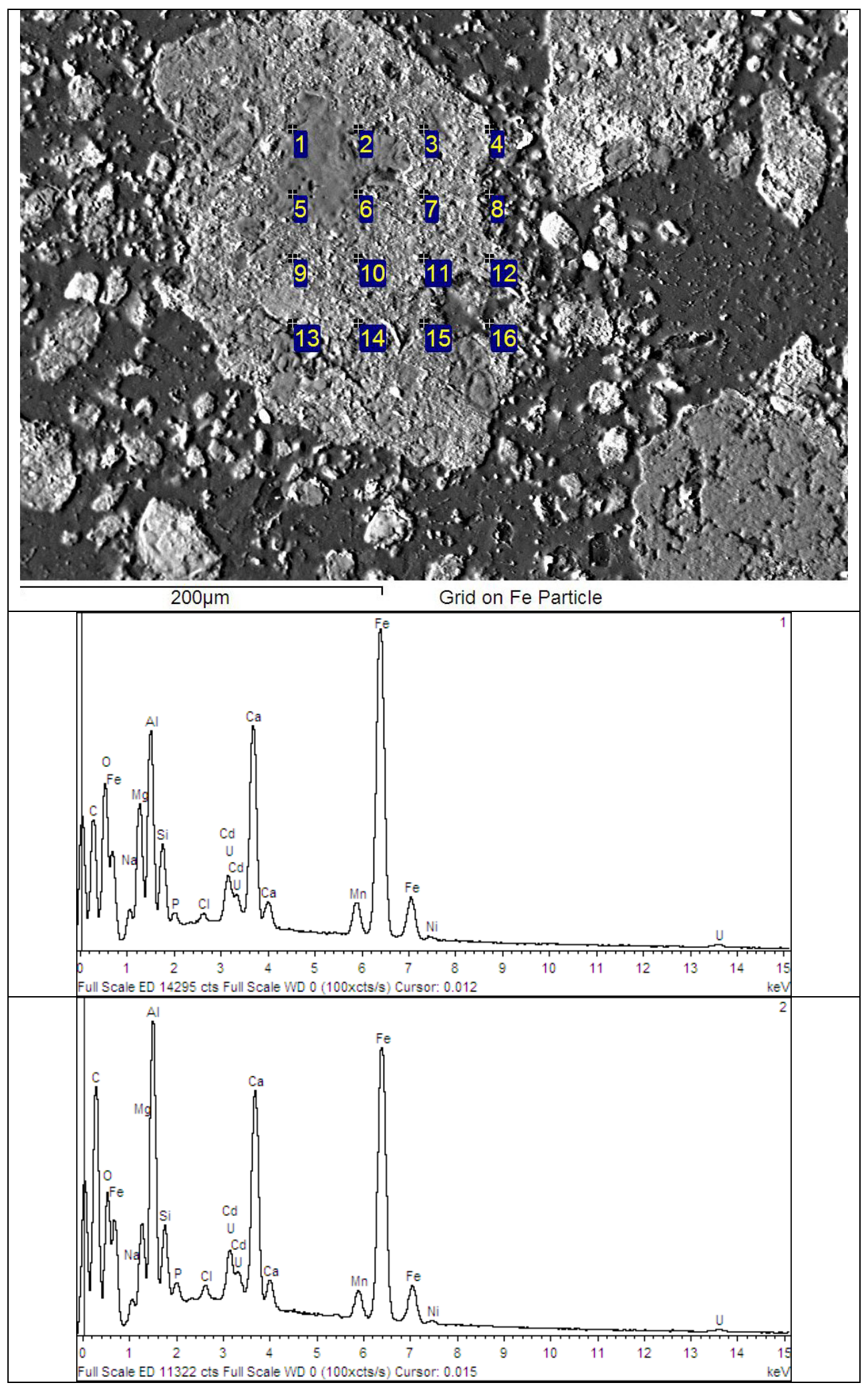

Figure A-4 WDS Grid Analysis of Matrix Containing Plutonium Particles in Sample FTF-18-1 
SRNL-STI-2012-00123

Revision 0

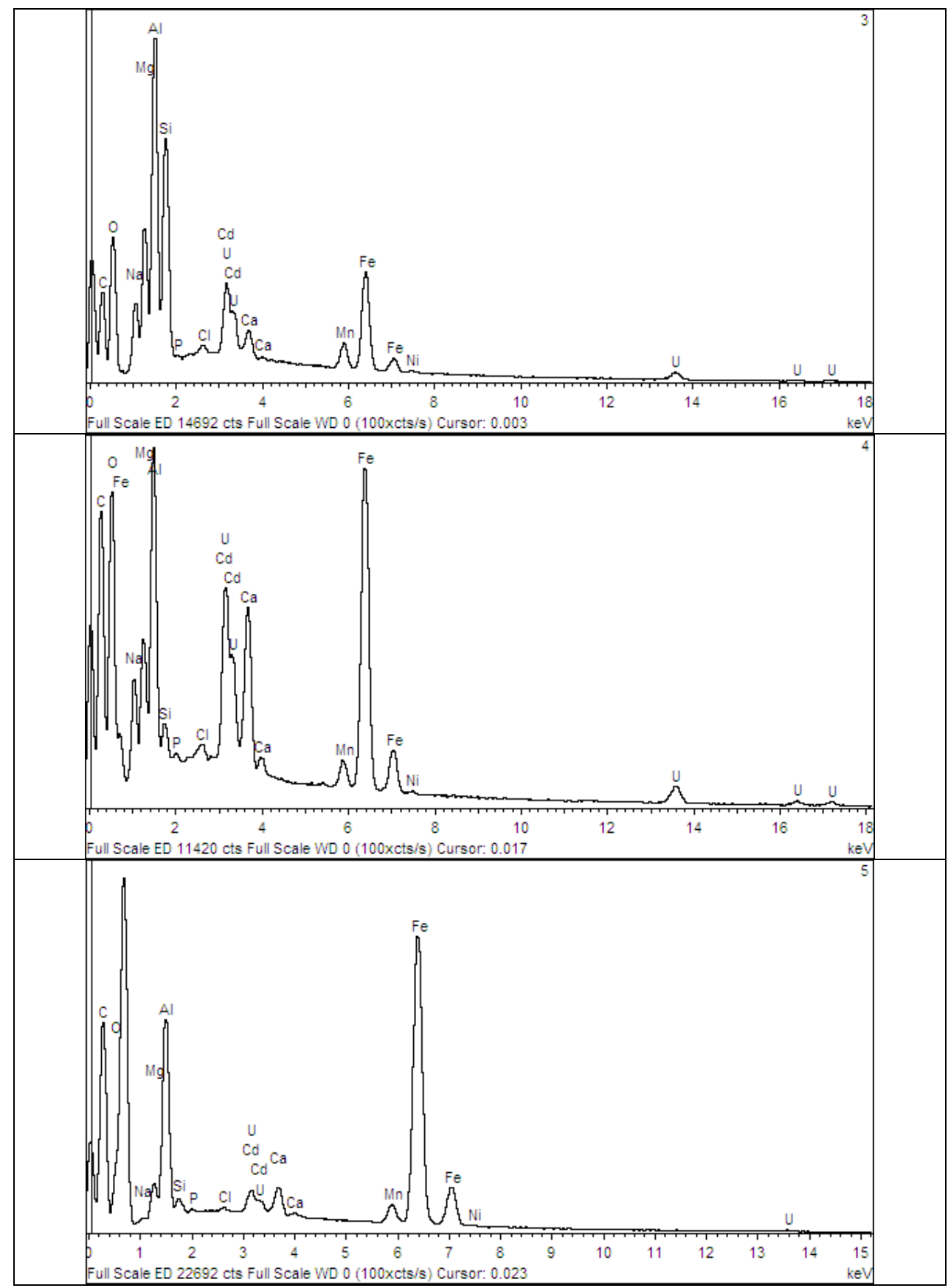

Figure A-4 WDS Grid Analysis of Matrix Containing Plutonium Particles in Sample FTF-18-1 (continued) 
SRNL-STI-2012-00123

Revision 0

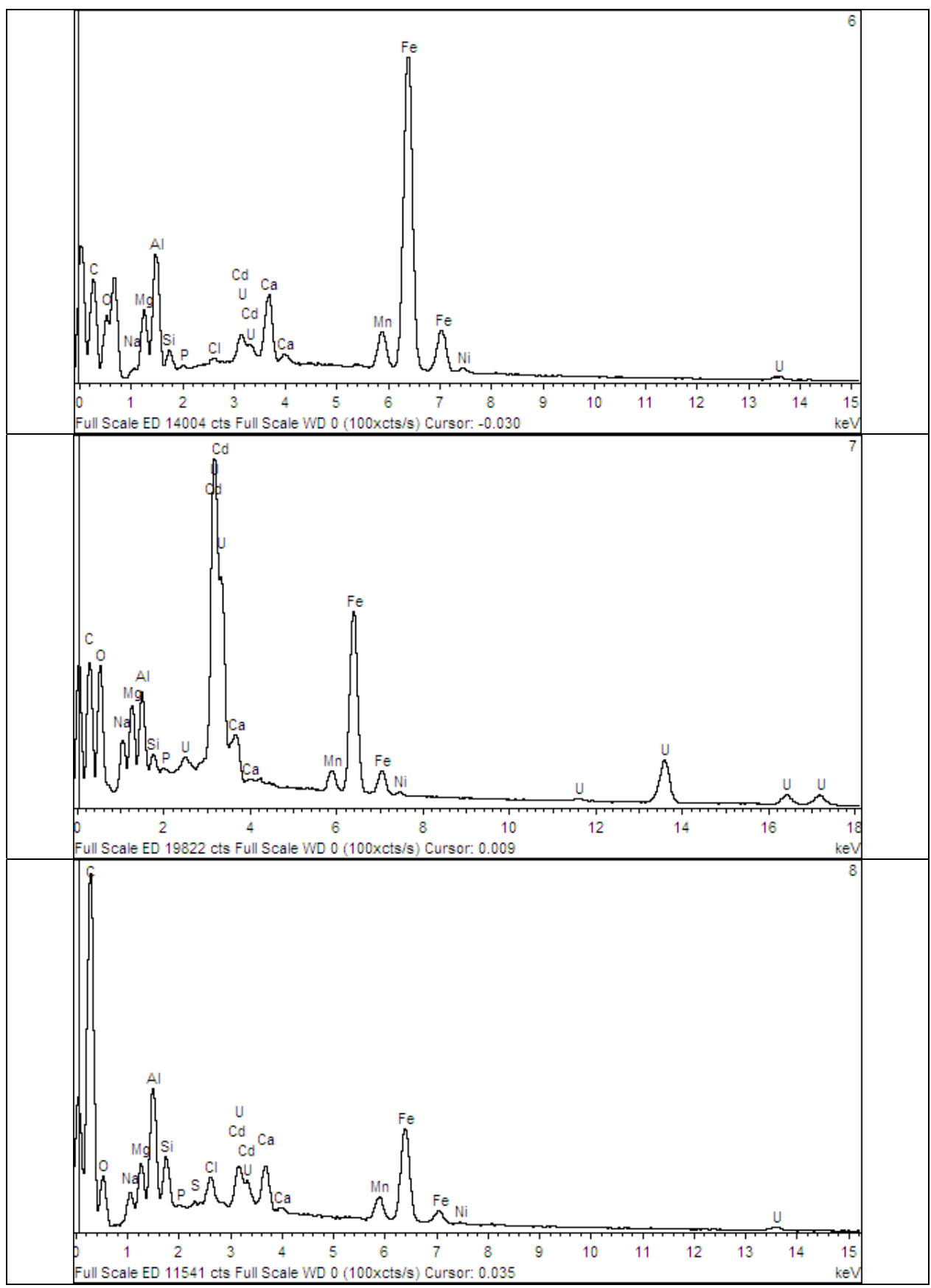

Figure A-4 WDS Grid Analysis of Matrix Containing Plutonium Particles in Sample FTF-18-1 (continued) 
SRNL-STI-2012-00123

Revision 0

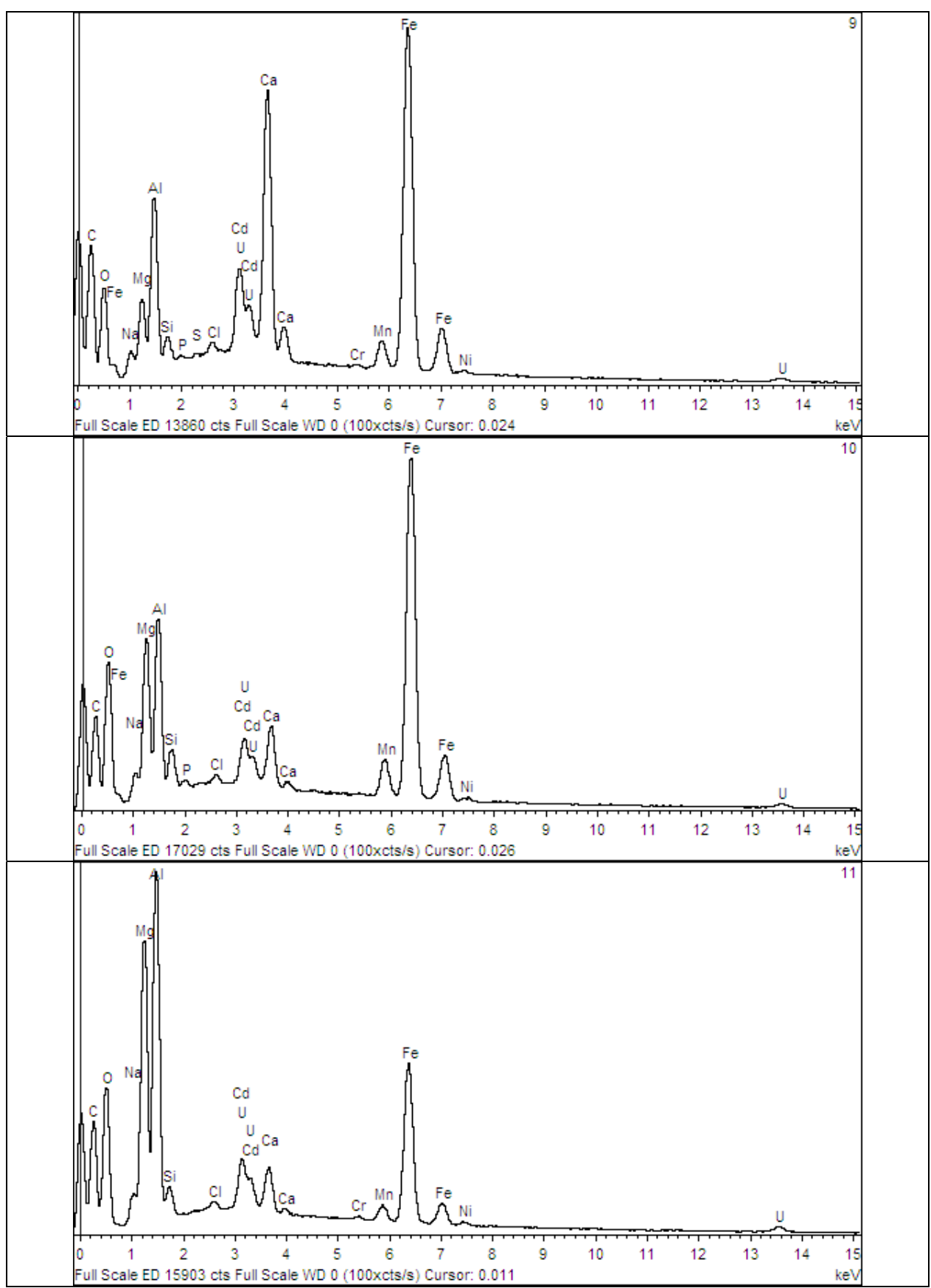

Figure A-4 WDS Grid Analysis of Matrix Containing Plutonium Particles in Sample FTF-18-1 (continued) 
SRNL-STI-2012-00123

Revision 0

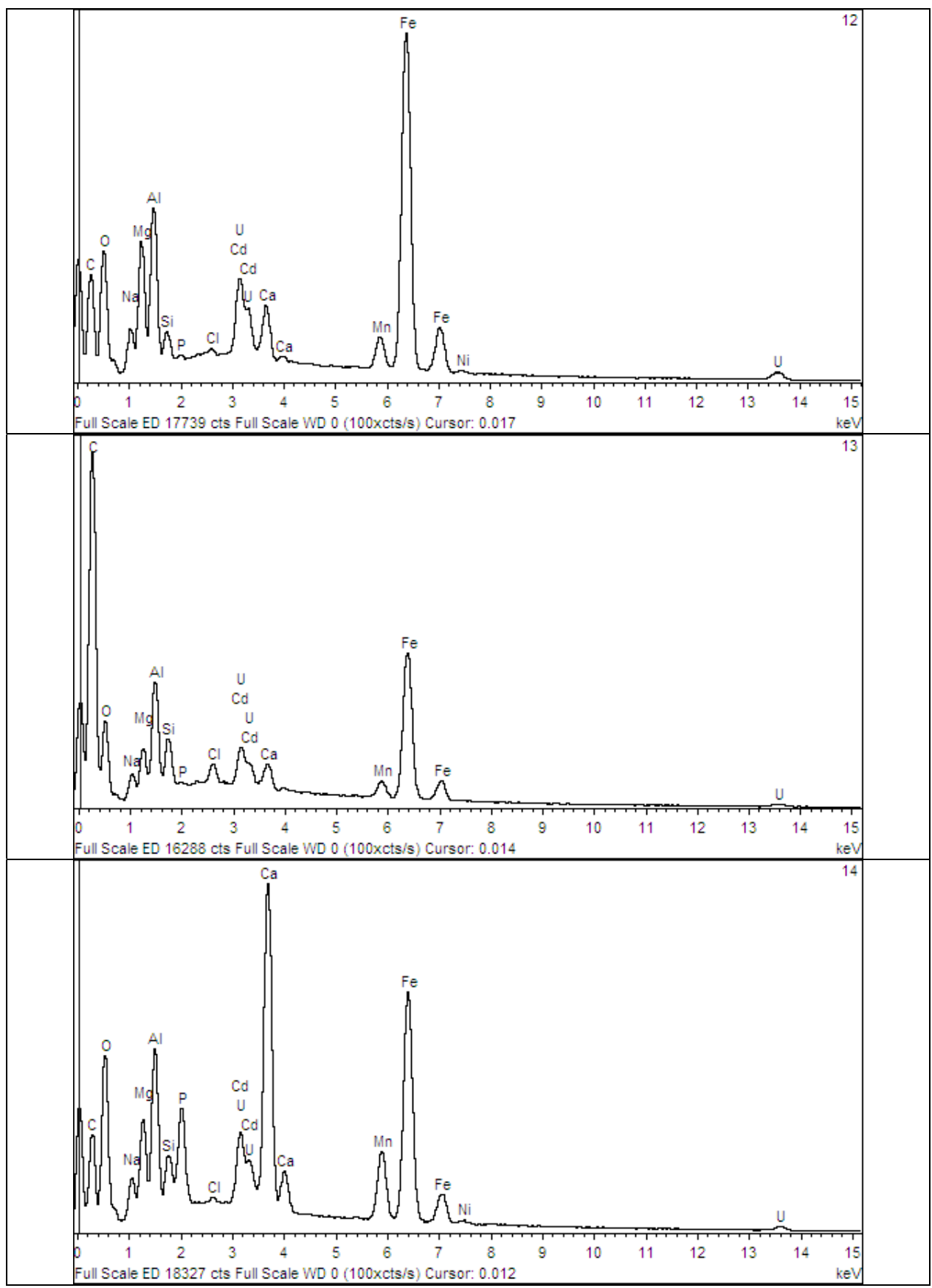

Figure A-4 WDS Grid Analysis of Matrix Containing Plutonium Particles in Sample FTF-18-1 (continued) 
SRNL-STI-2012-00123

Revision 0

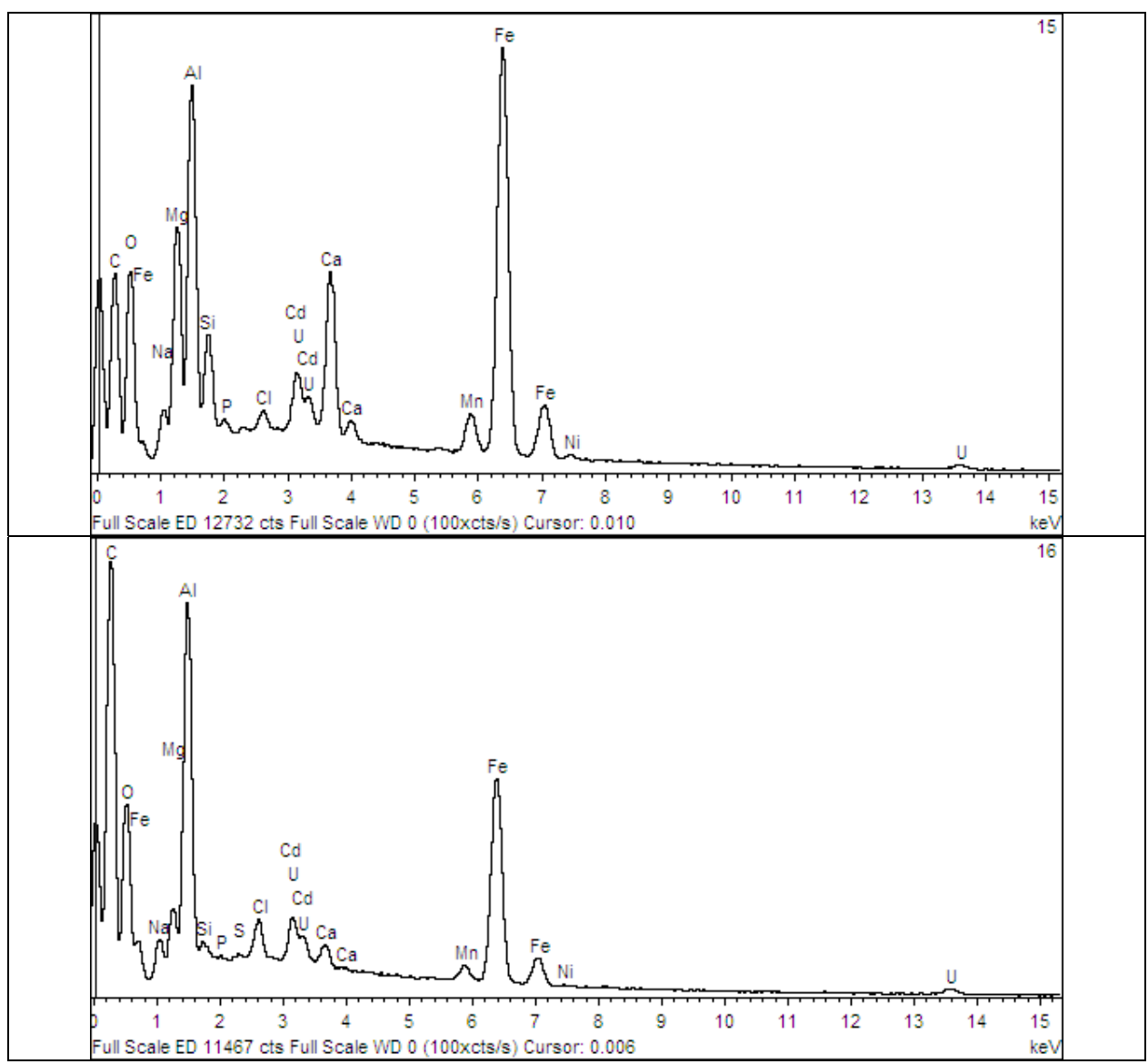

Figure A-4 WDS Grid Analysis of Matrix Containing Plutonium Particles in Sample FTF-18-1 (continued) 


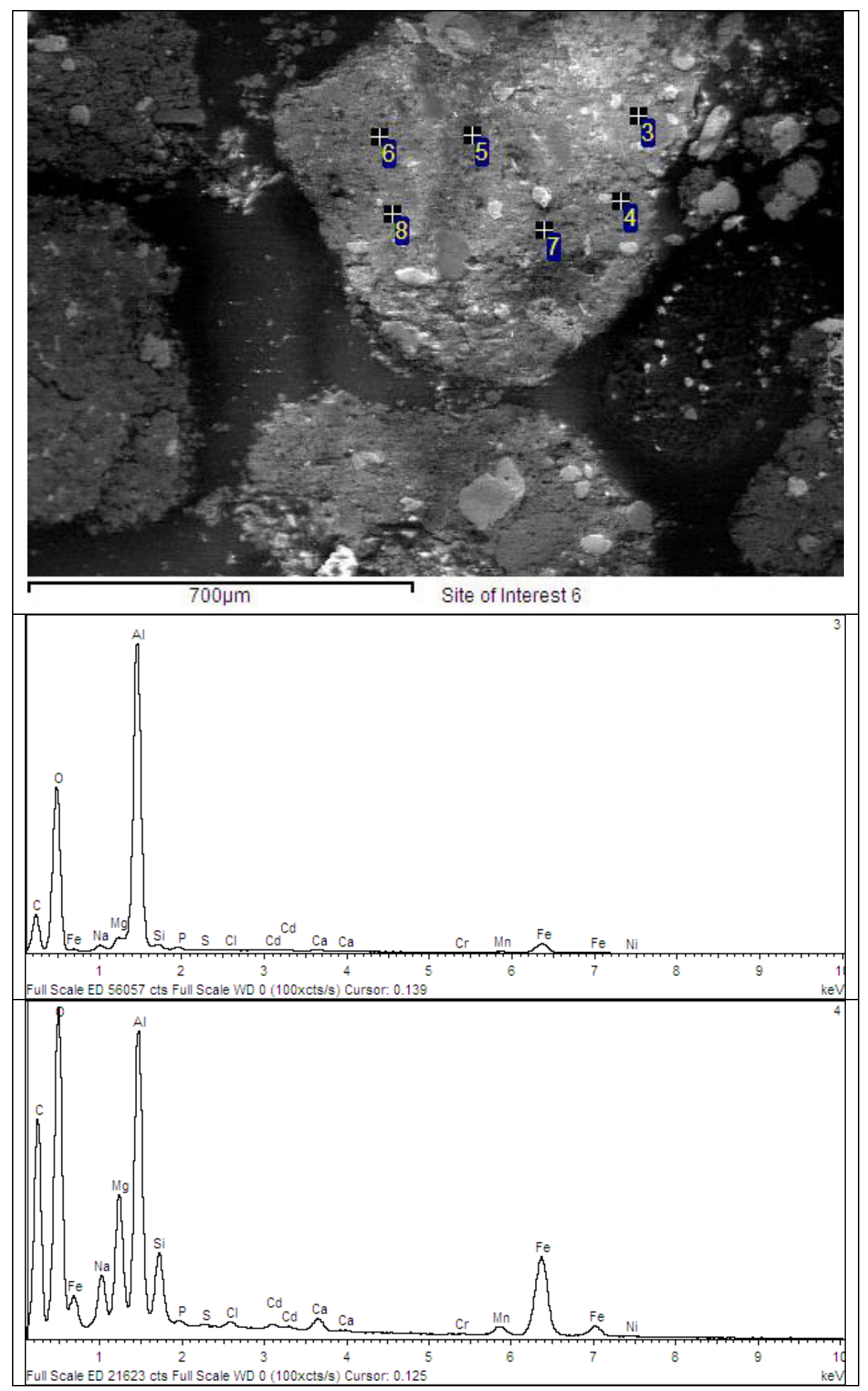

Figure A-5 EDS Grid Analysis of Spots on Particles in Sample FTF-18-3 
SRNL-STI-2012-00123

Revision 0

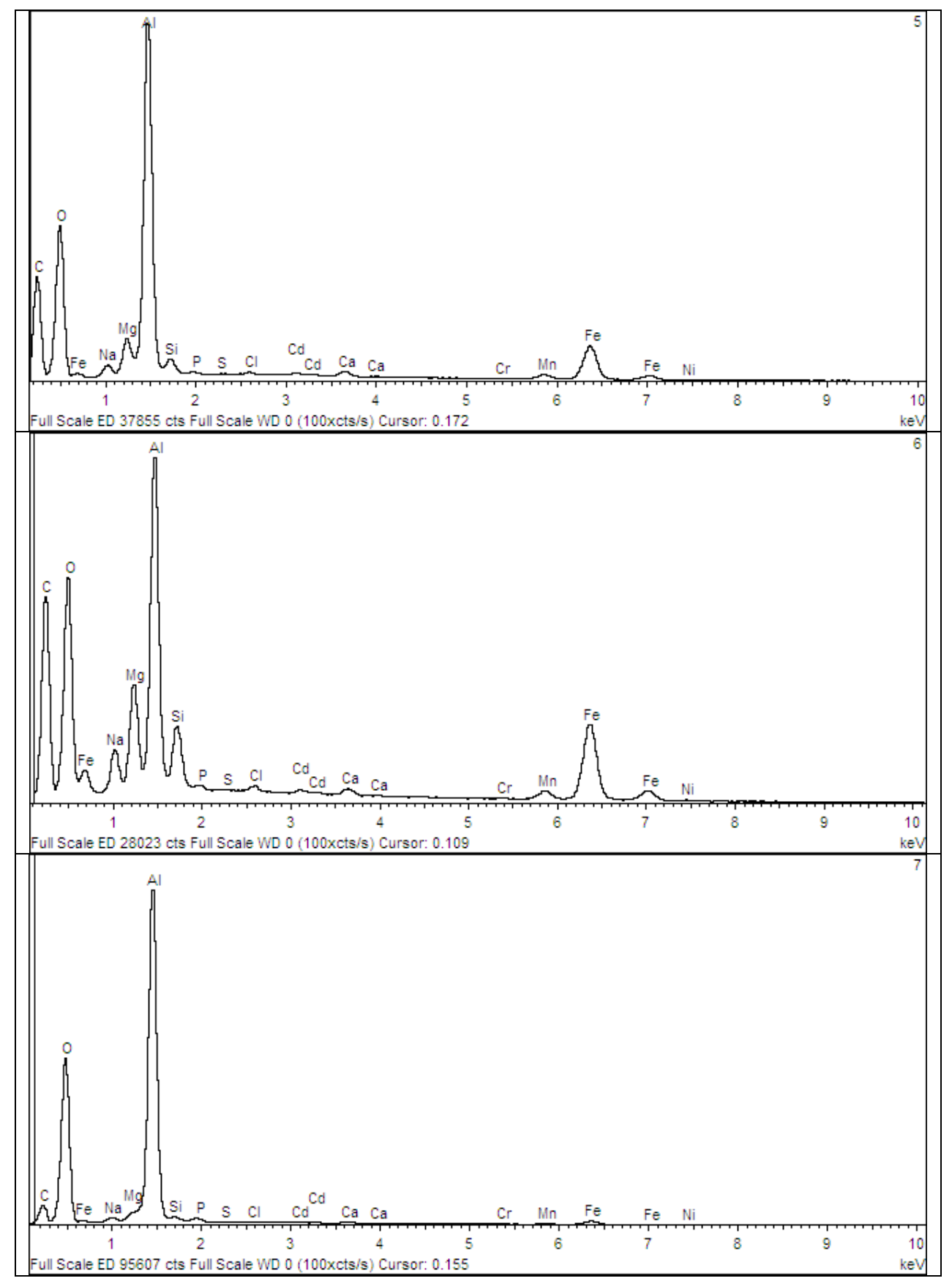

Figure A-5 EDS Grid Analysis of Spots on Particles in Sample FTF-18-3 (continued) 
SRNL-STI-2012-00123

Revision 0

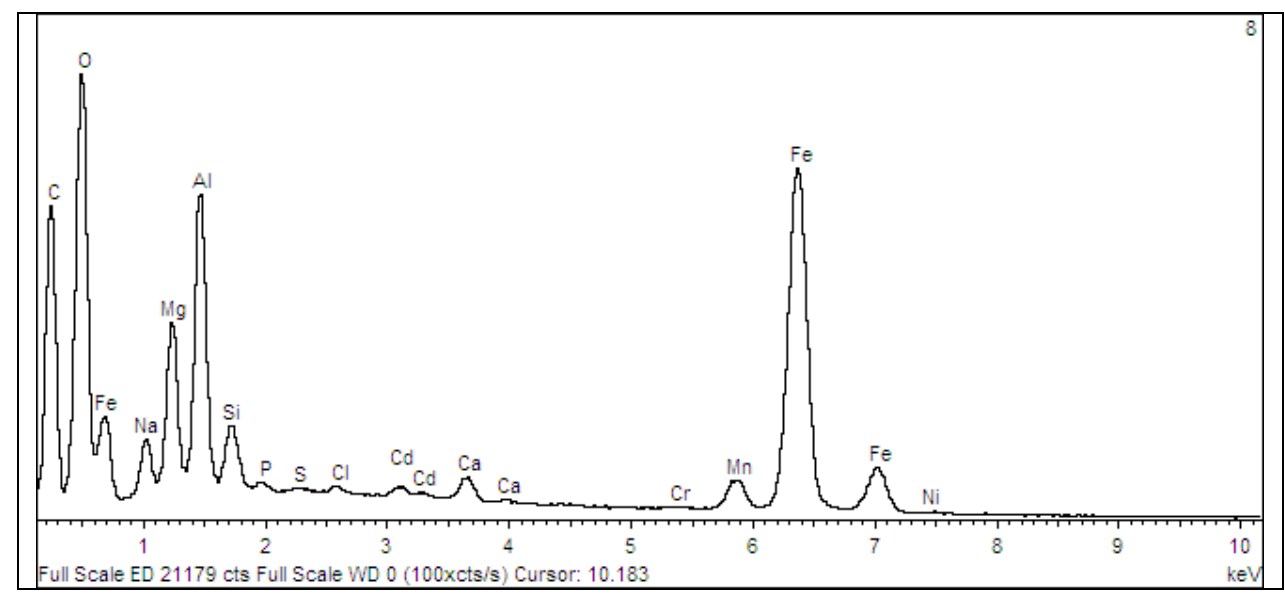

Figure A-5 EDS Grid Analysis of Spots on Particles in Sample FTF-18-3 (continued) 


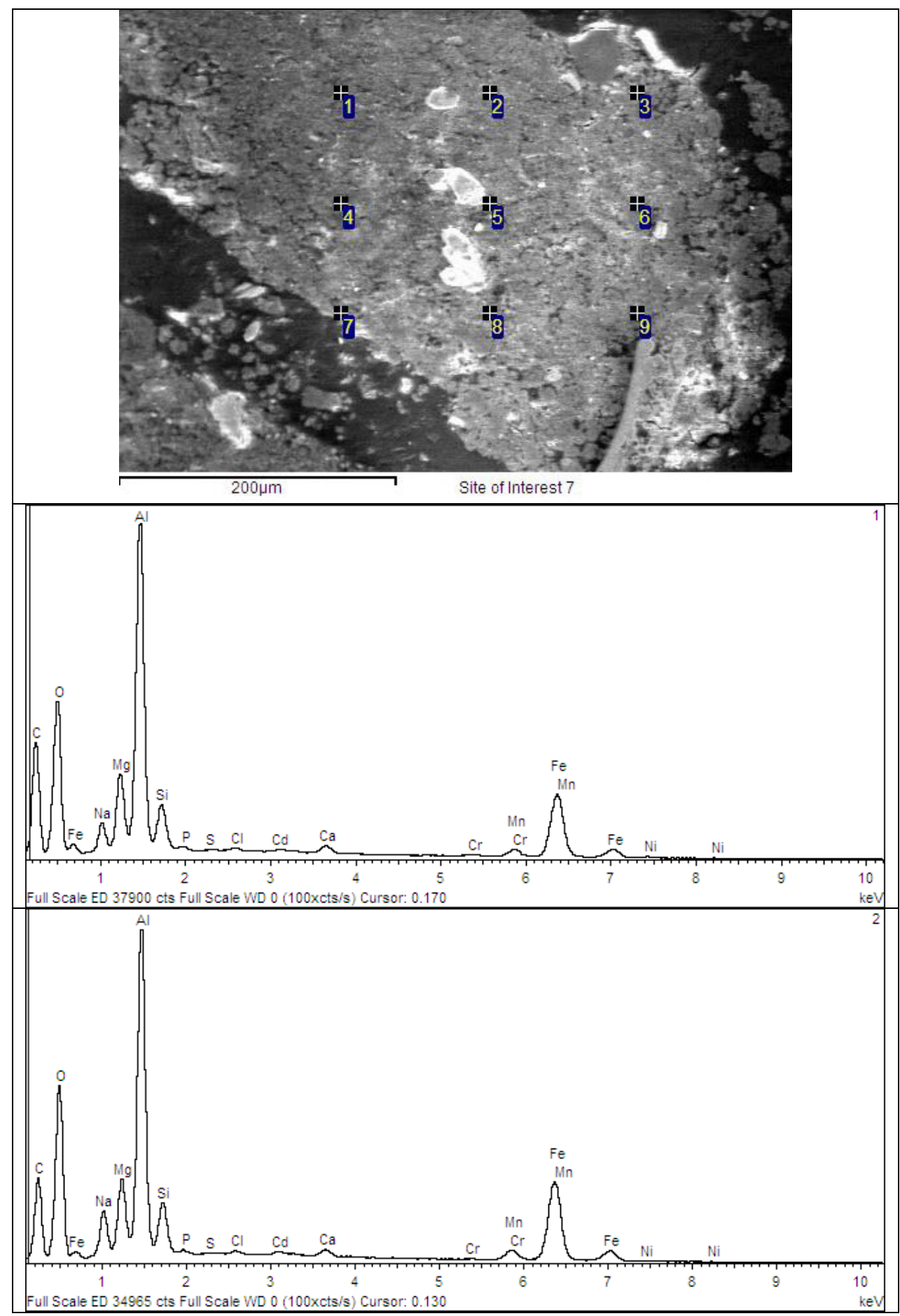

Figure A-6 EDS Grid Analysis of Spots on Particles in Sample FTF-18-3 
SRNL-STI-2012-00123

Revision 0

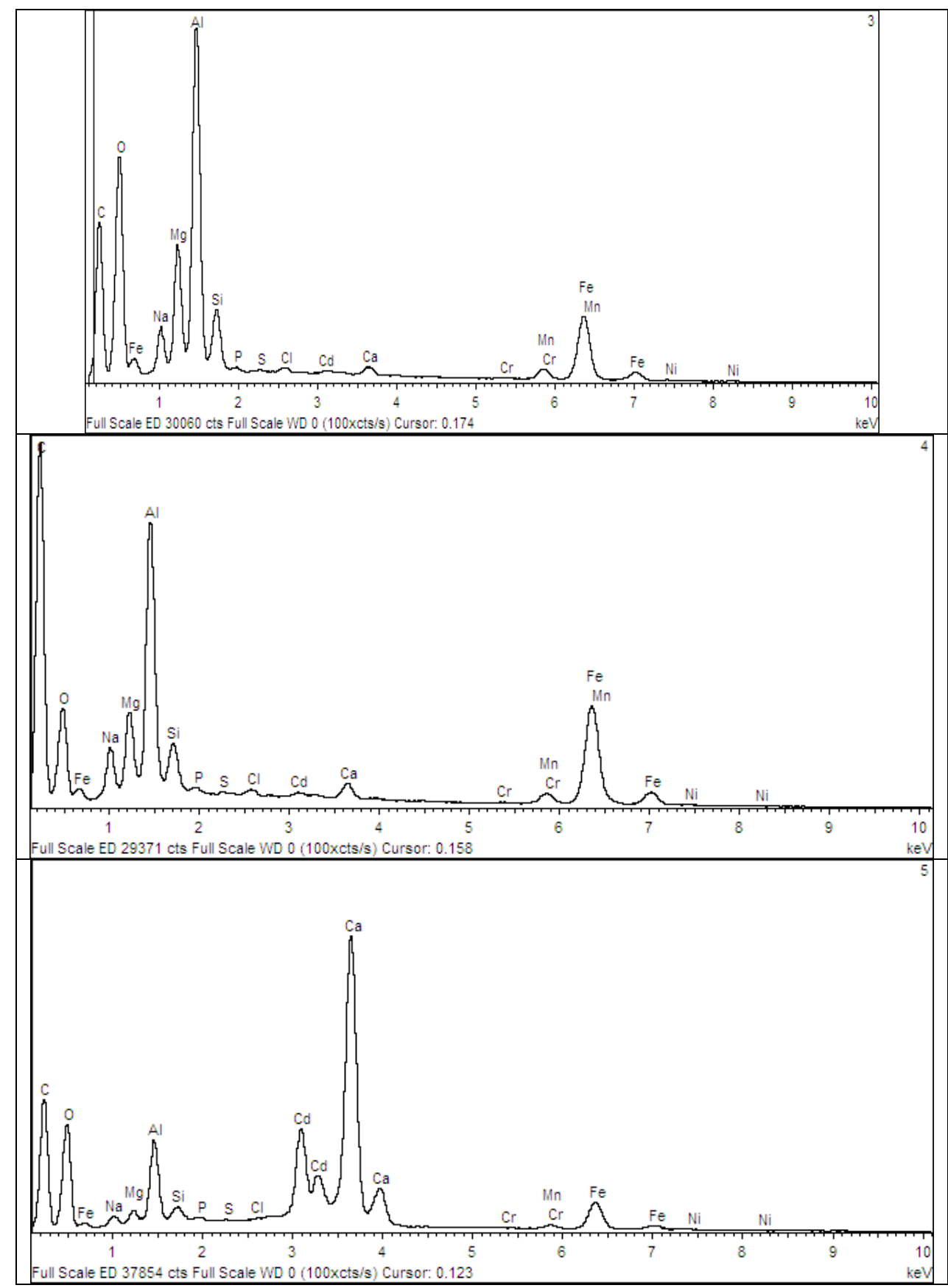

Figure A-6 EDS Grid Analysis of Spots on Particles in Sample FTF-18-3 (continued) 
SRNL-STI-2012-00123

Revision 0

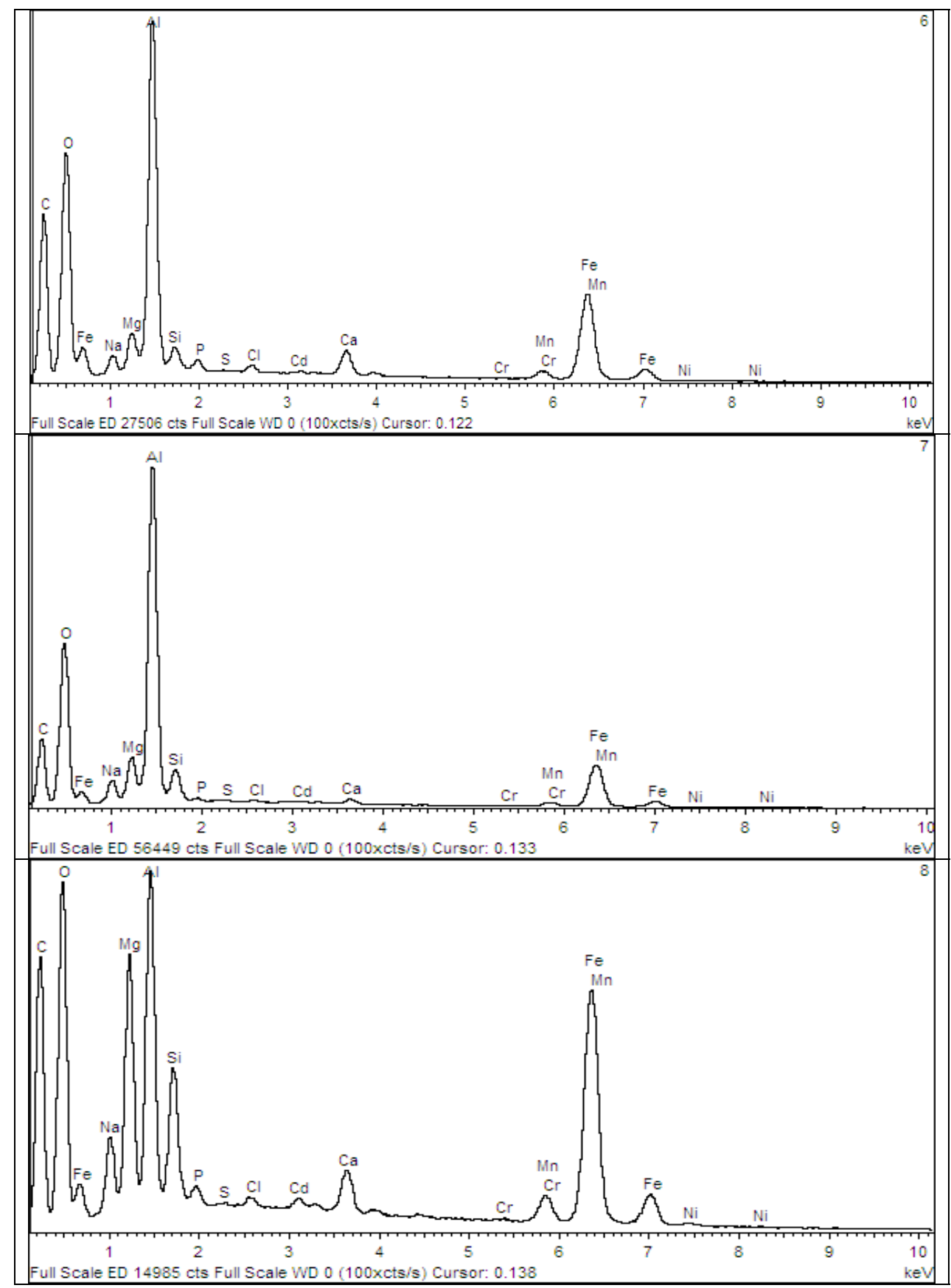

Figure A-6 EDS Grid Analysis of Spots on Particles in Sample FTF18-3 (continued) 
SRNL-STI-2012-00123

Revision 0

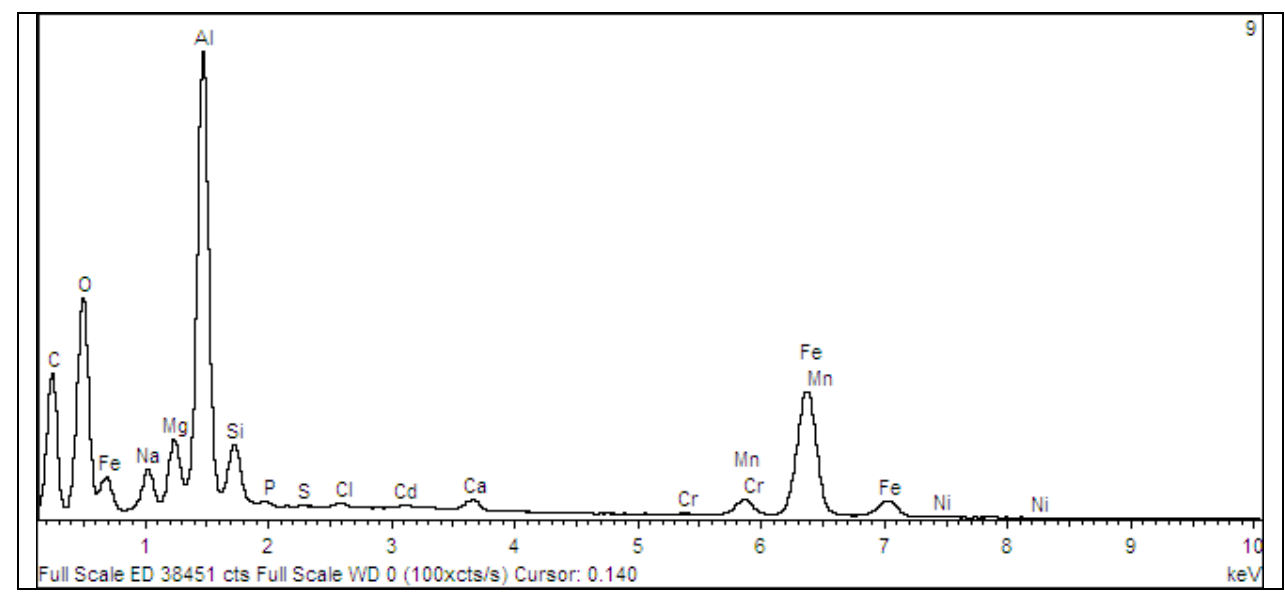

Figure A-6 EDS Grid Analysis of Spots on Particles in Sample FTF-18-3 (continued) 


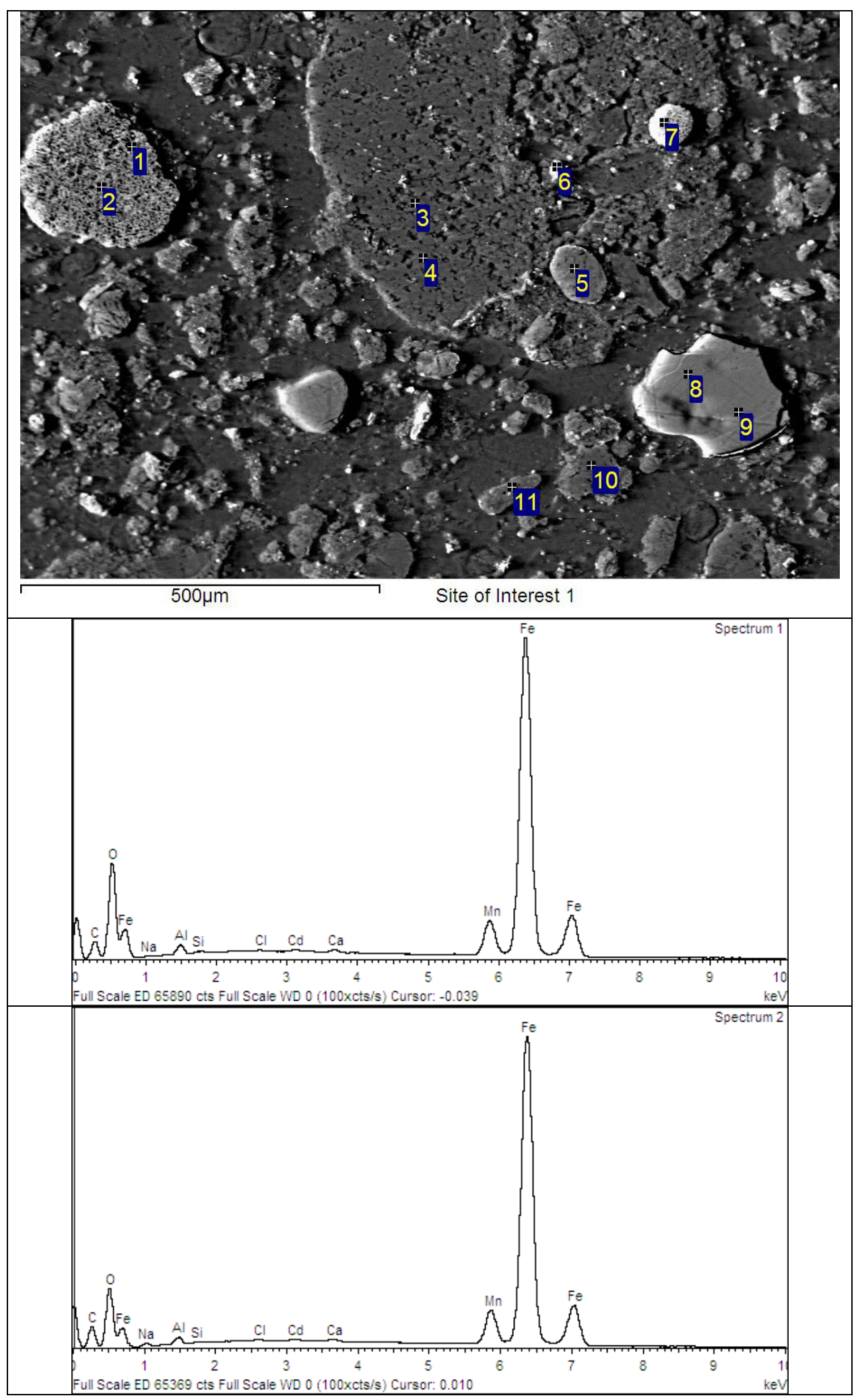

Figure A-7 EDS Grid Analysis of Spots on Particles in Sample FTF-18-4 
SRNL-STI-2012-00123

Revision 0

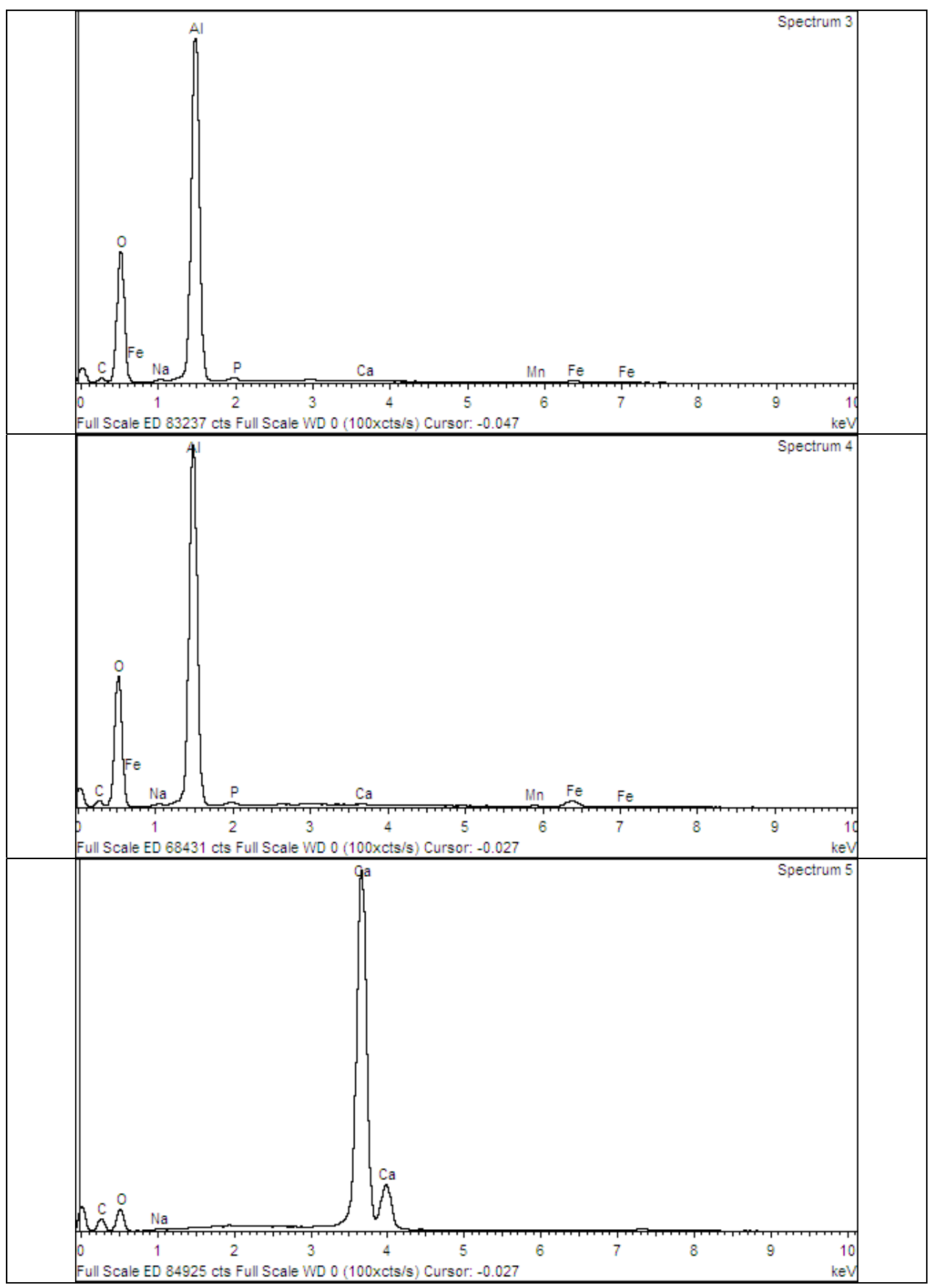

Figure A-7 EDS Grid Analysis of Spots on Particles in Sample FTF-18-4 (continued) 
SRNL-STI-2012-00123

Revision 0

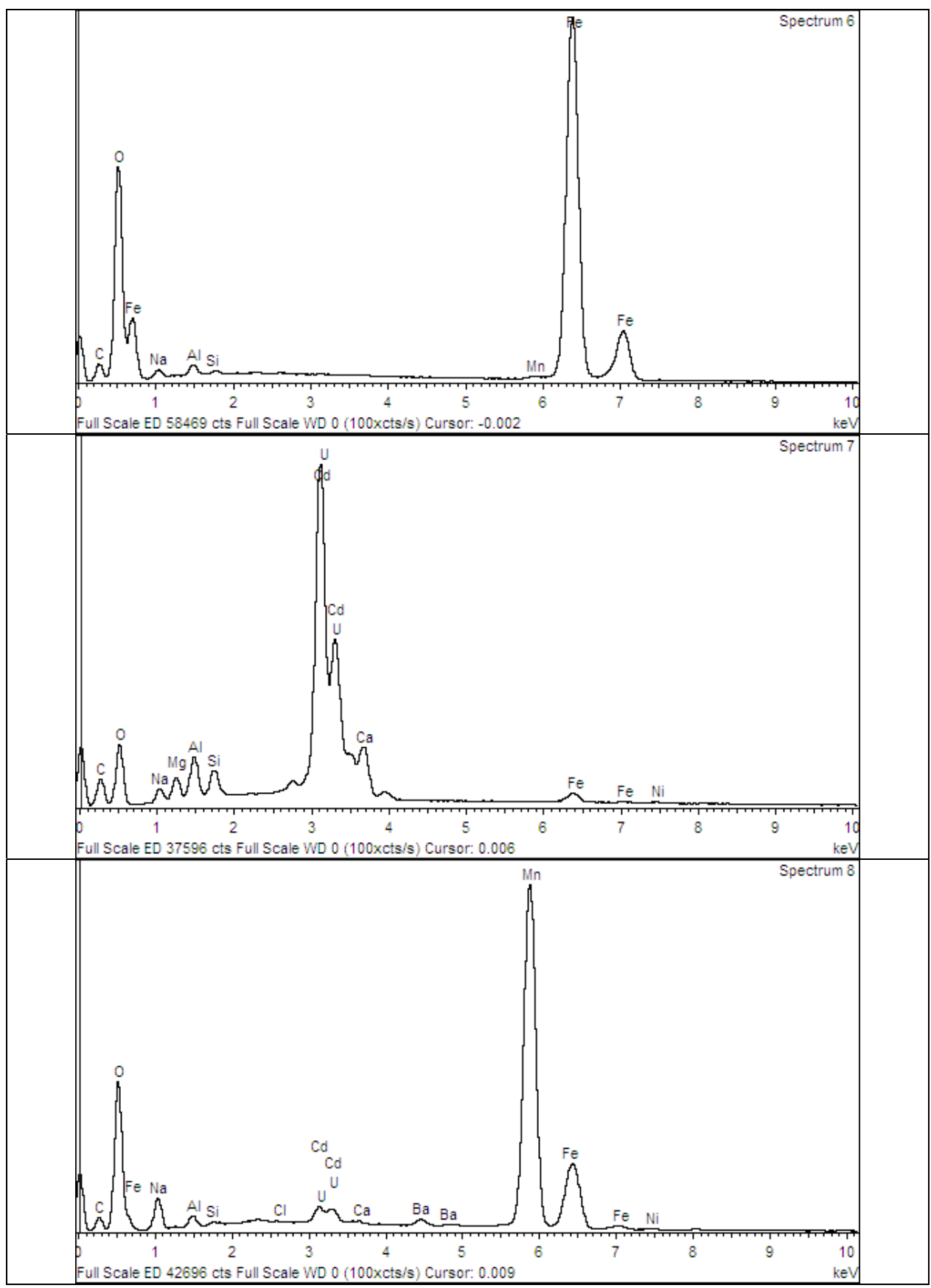

Figure A-7 EDS Grid Analysis of Spots on Particles in Sample FTF-18-4 (continued) 
SRNL-STI-2012-00123

Revision 0

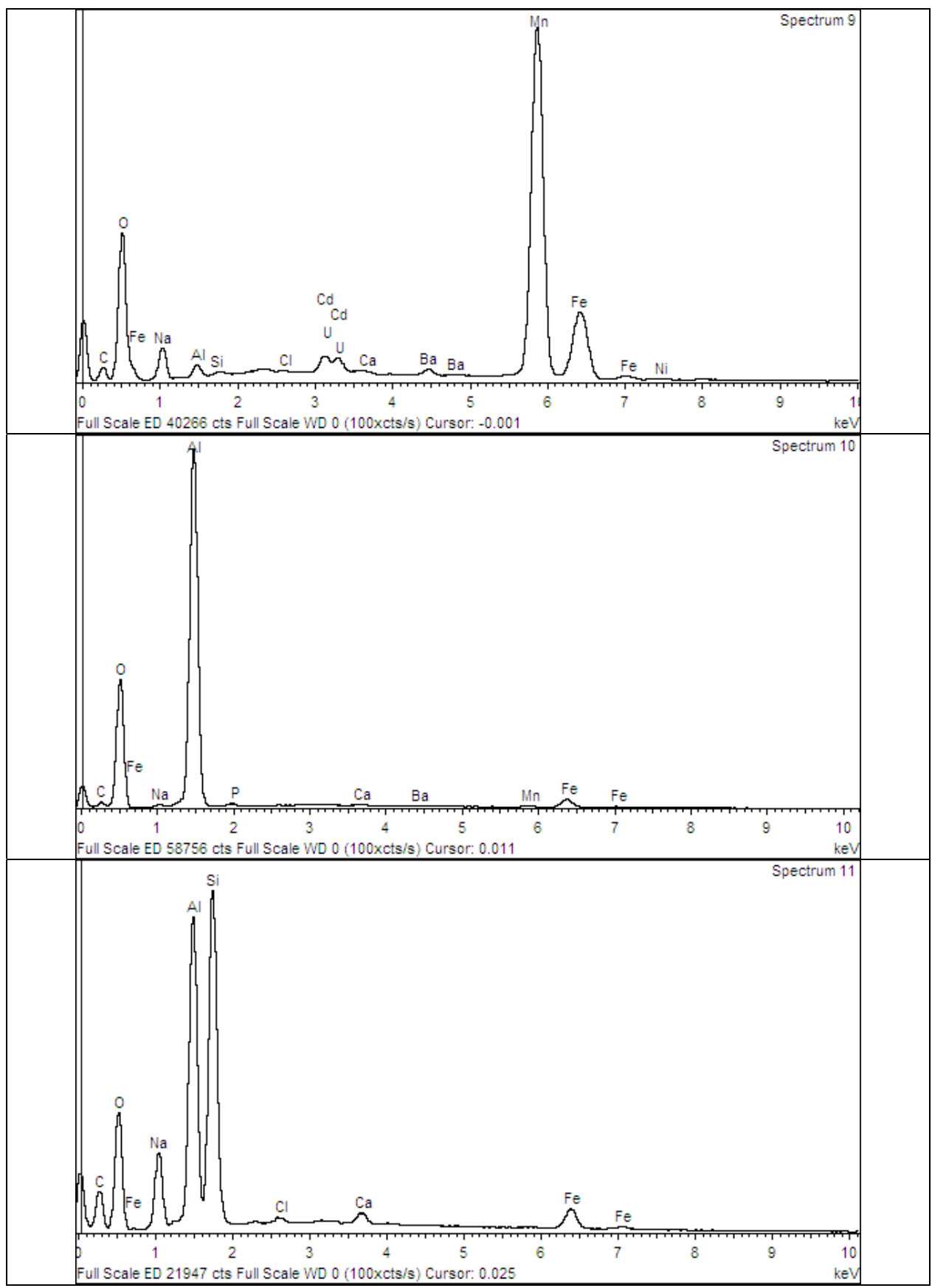

Figure A-7 EDS Grid Analysis of Spots on Particles in Sample FTF-18-4 (continued) 


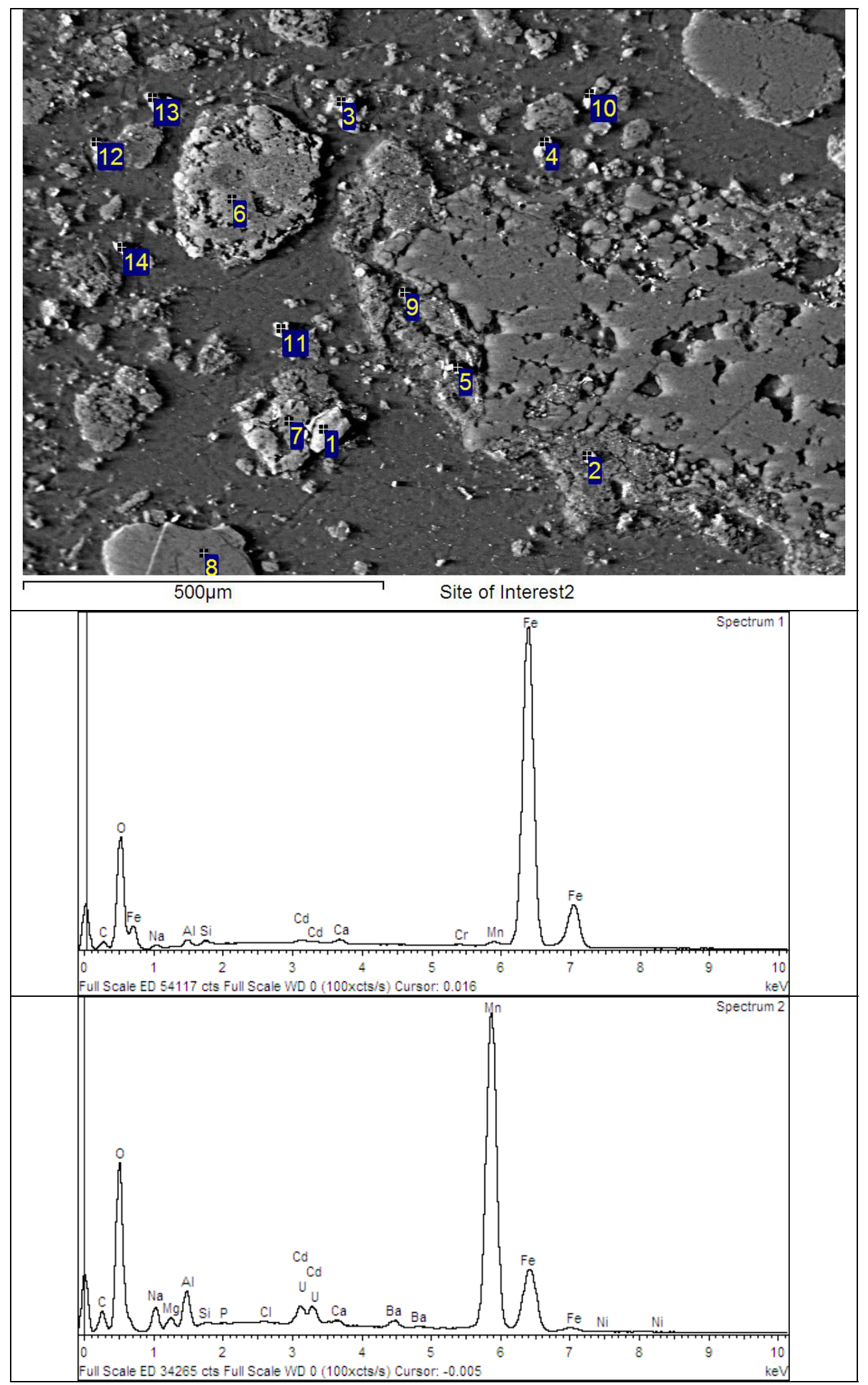

Figure A-8 EDS Grid Analysis of Spots on Particles in Sample FTF18-4 
SRNL-STI-2012-00123

Revision 0

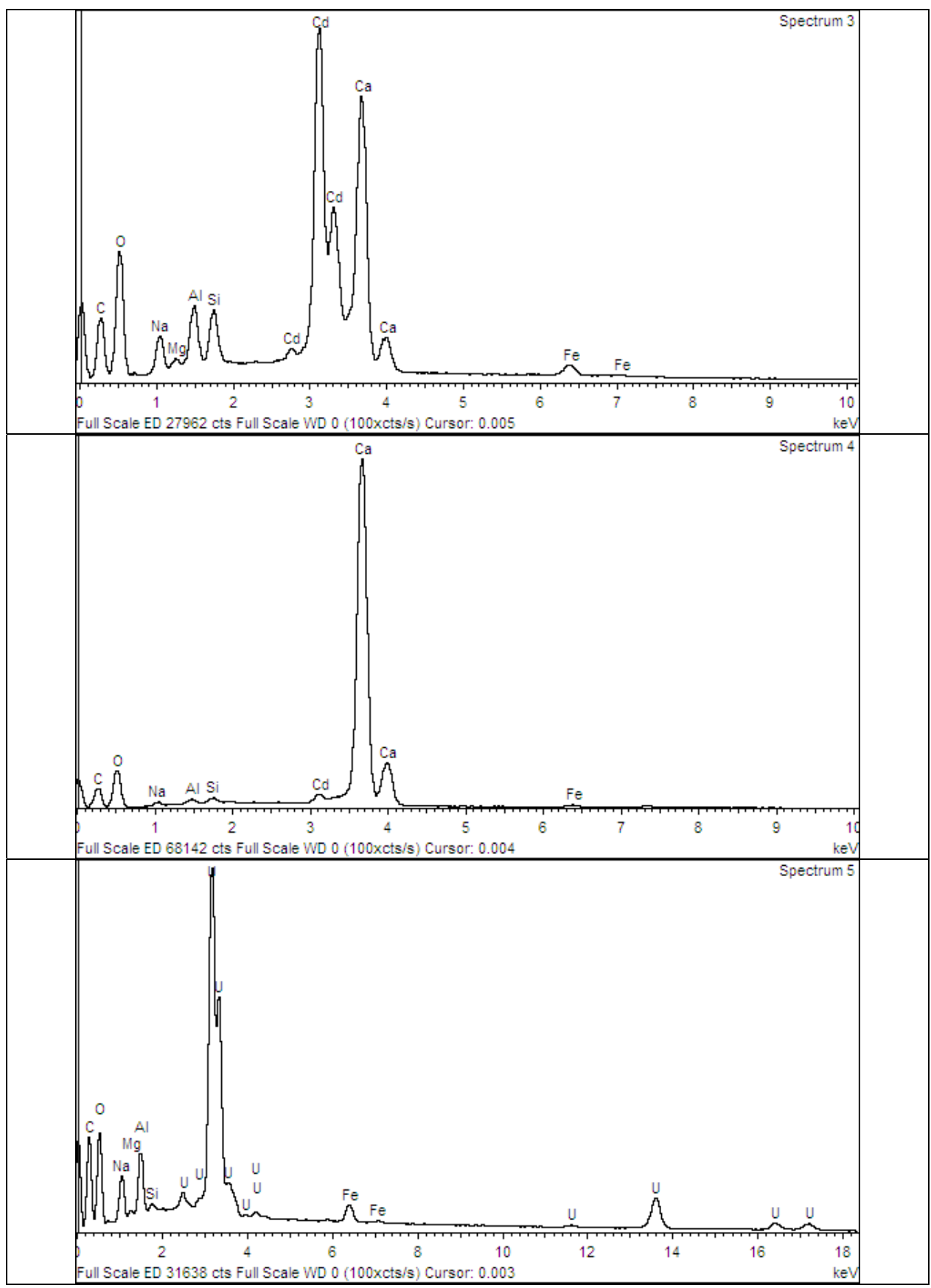

Figure A-8 EDS Grid Analysis of Spots on Particles in Sample FTF-18-4 (continued) 
SRNL-STI-2012-00123

Revision 0

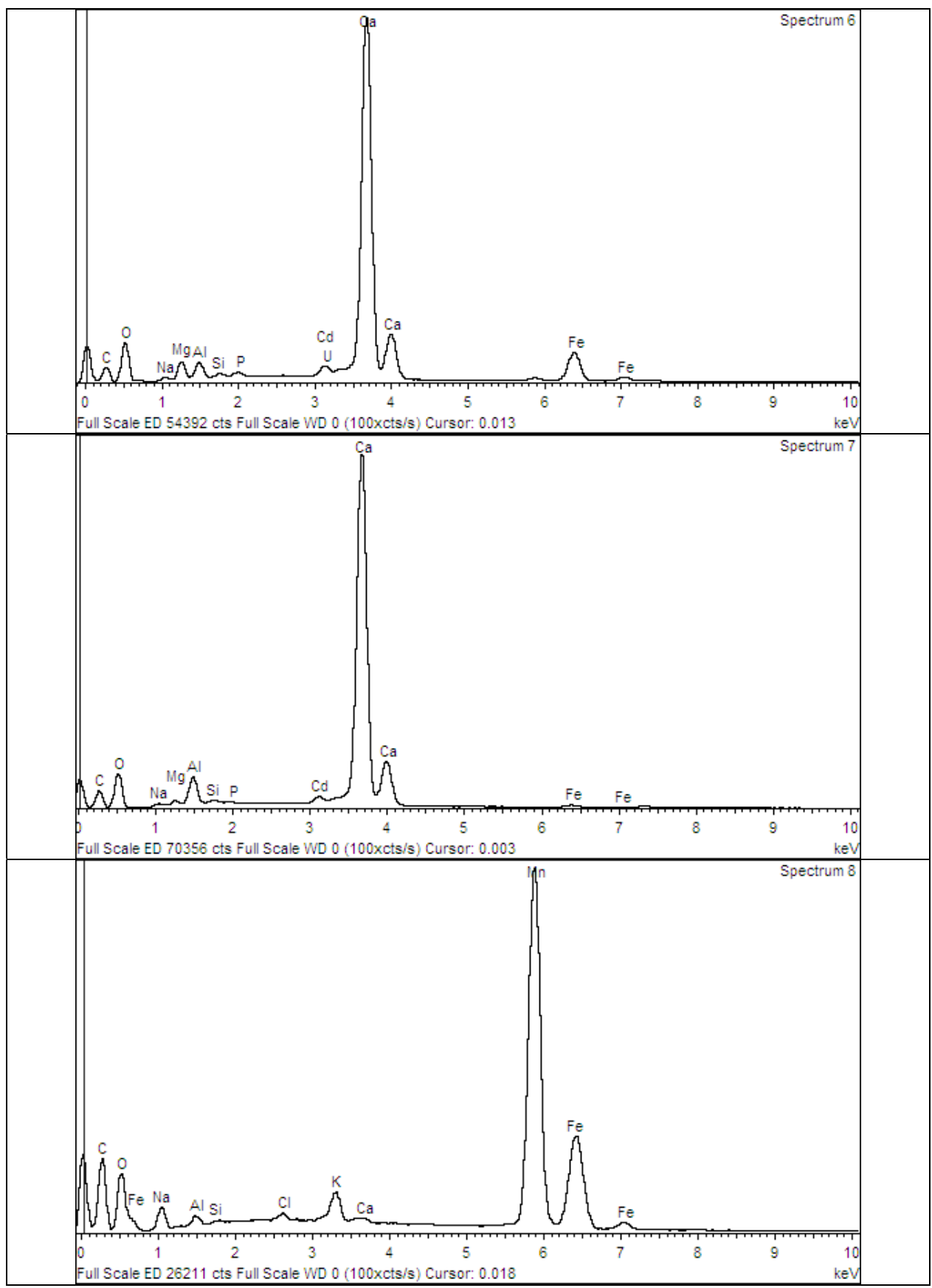

Figure A-8 EDS Grid Analysis of Spots on Particles in Sample FTF-18-4 (continued) 
SRNL-STI-2012-00123

Revision 0

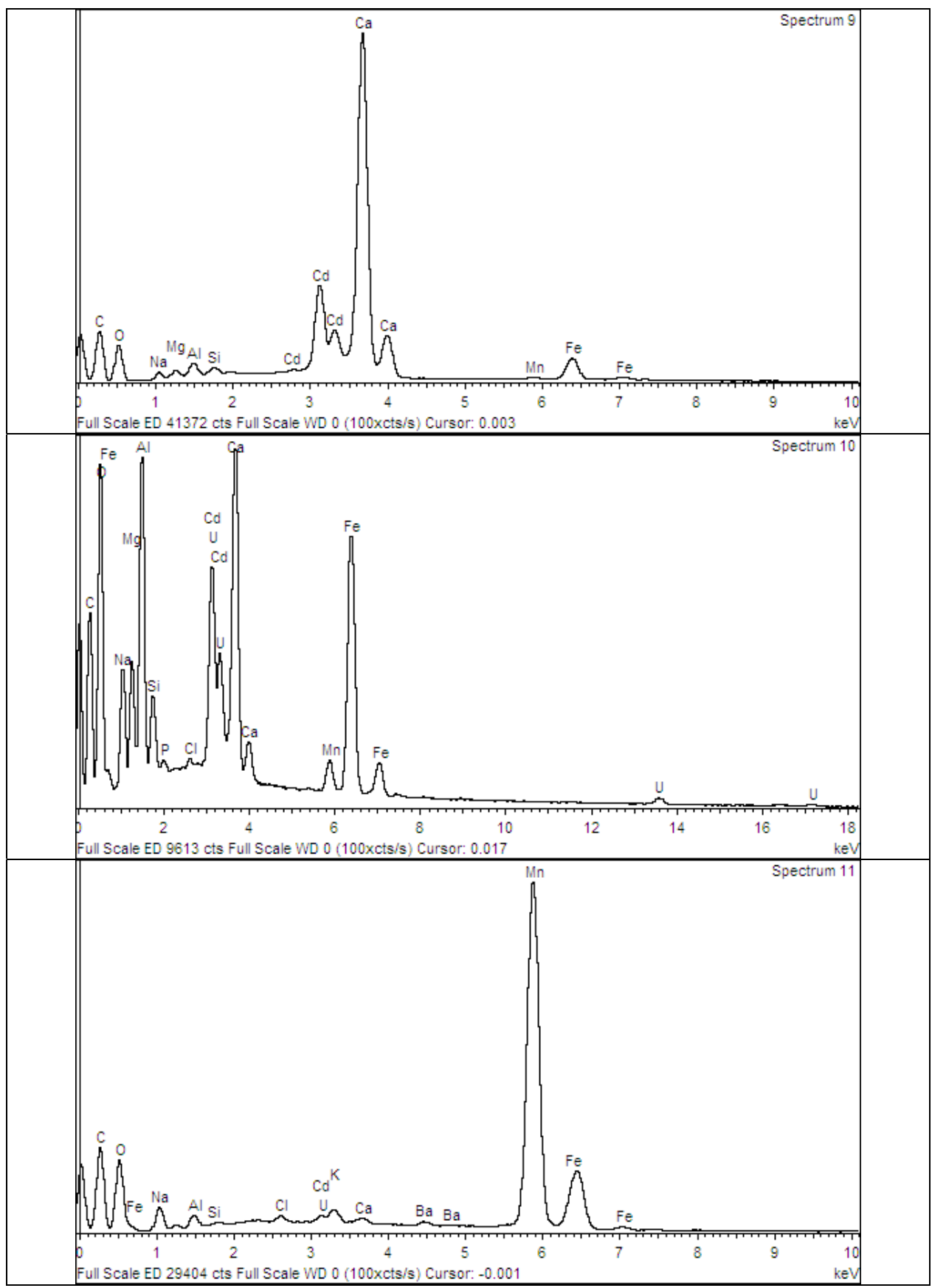

Figure A-8 EDS Grid Analysis of Spots on Particles in Sample FTF-18-4 (continued) 
SRNL-STI-2012-00123

Revision 0

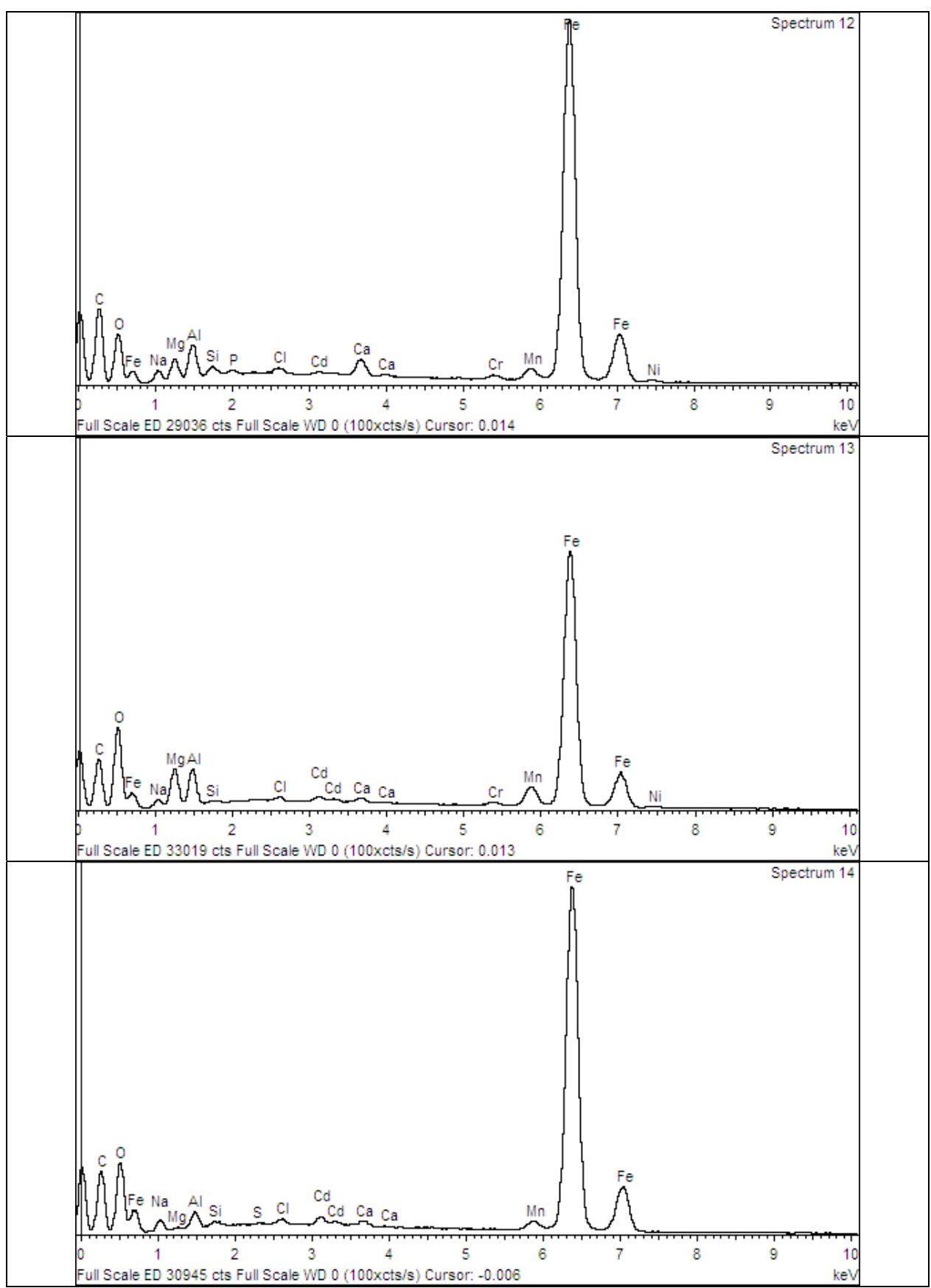

Figure A-8 EDS Grid Analysis of Spots on Particles in Sample FTF-18-4 (continued) 


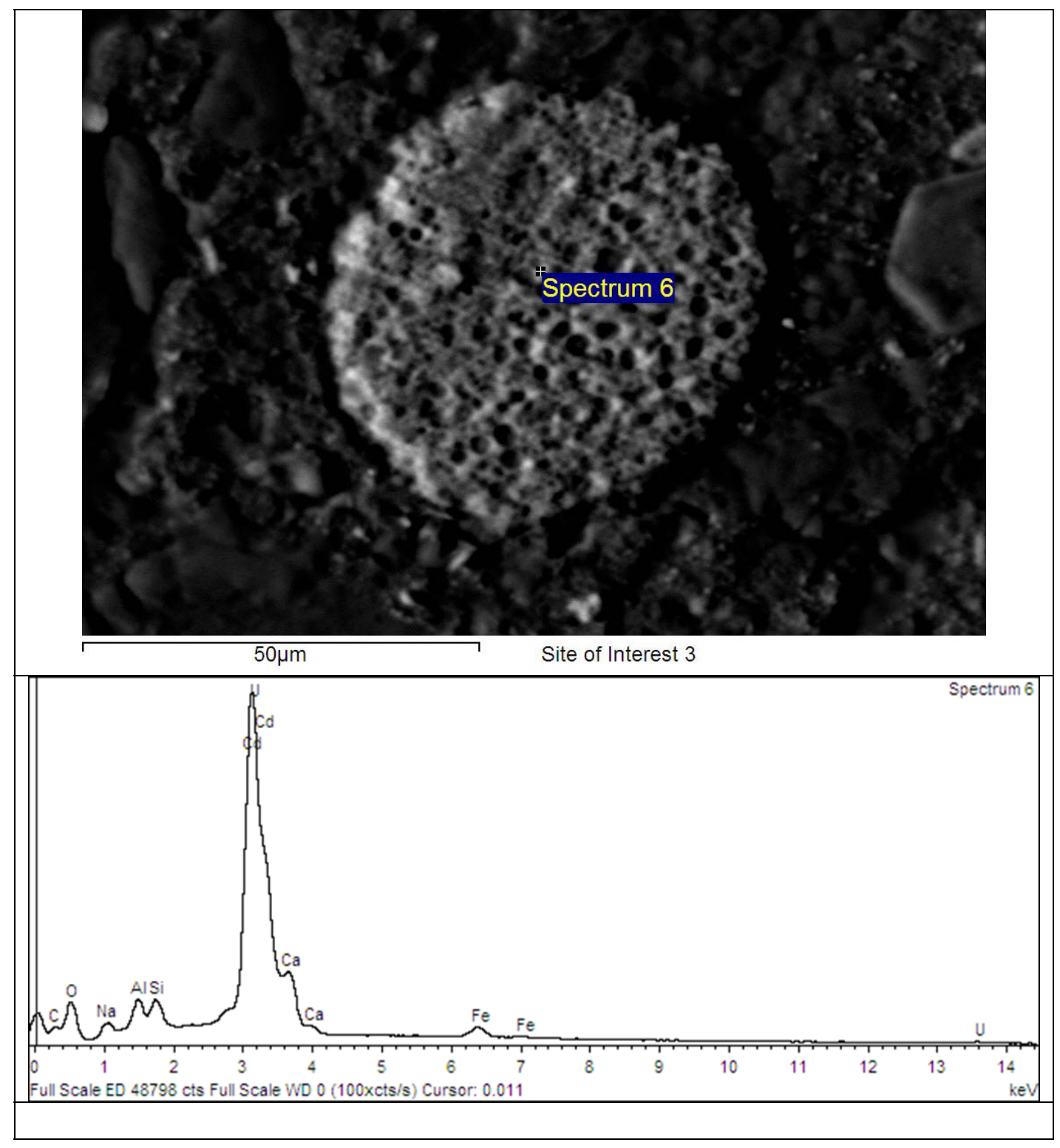

Figure A-9 EDS Analysis of Spot on a Particle in Sample FTF-18-4 


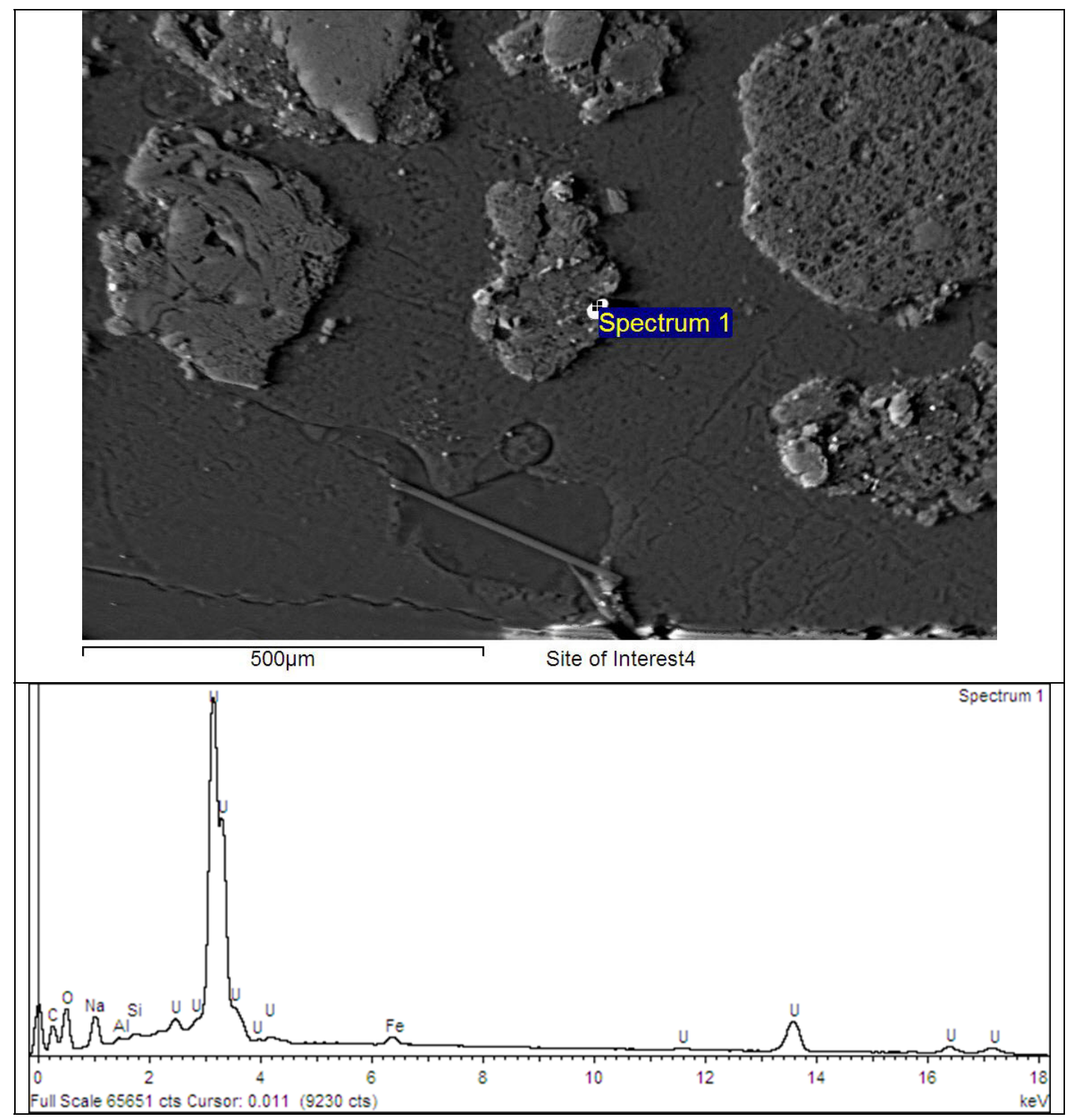

Figure A-10 EDS Grid Analysis of a Uranium Particle in Sample FTF-18-4 


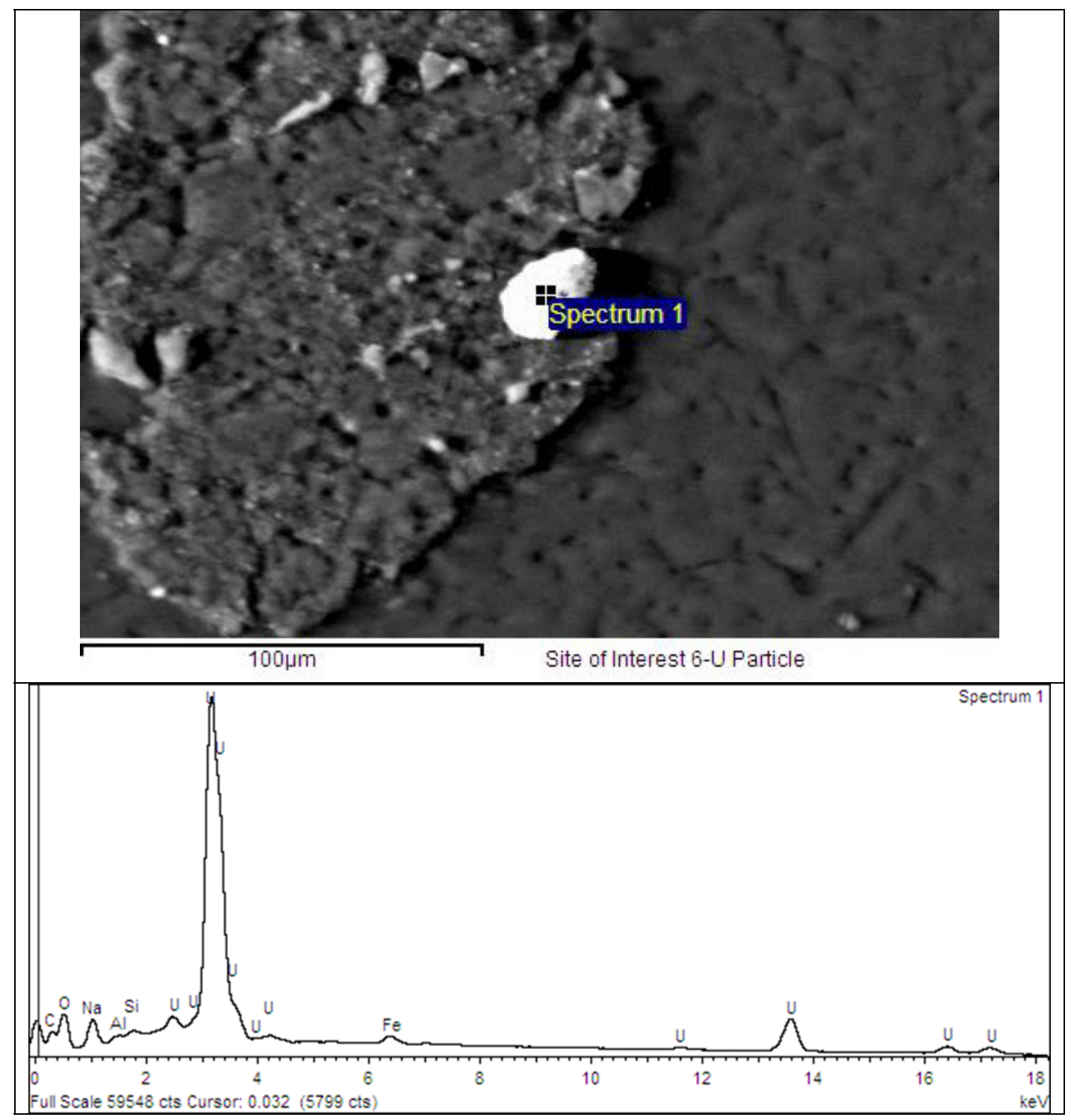

Figure A-11 EDS Grid Analysis of a Uranium Particle in Sample FTF-18-4 
SRNL-STI-2012-00123

Revision 0

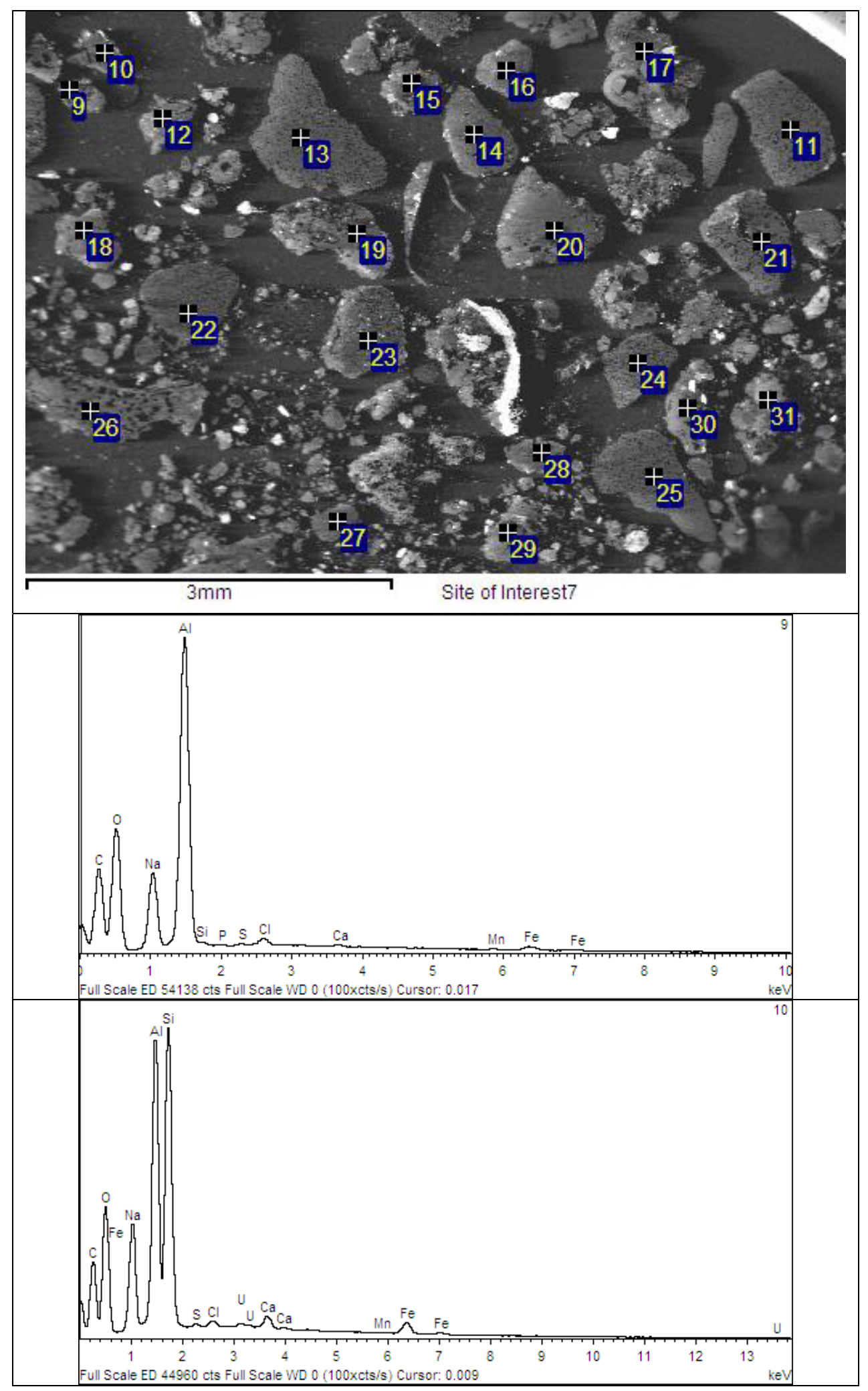

Figure A-12 EDS Grid Analysis of Spots on Particles in Sample FTF-18-4 
SRNL-STI-2012-00123

Revision 0

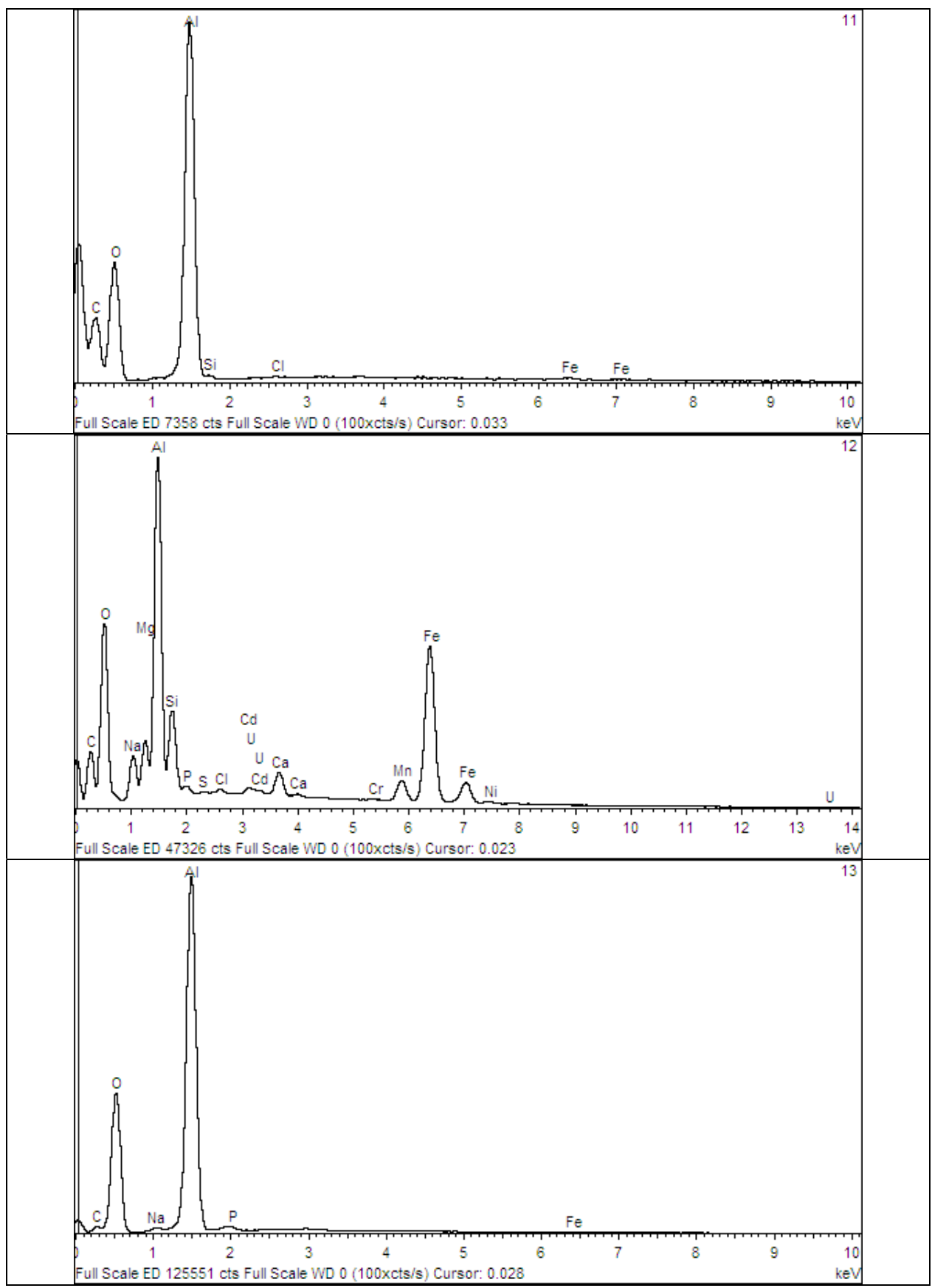

Figure A-12 EDS Grid Analysis of Spots on Particles in Sample FTF-18-4 (continued) 
SRNL-STI-2012-00123

Revision 0

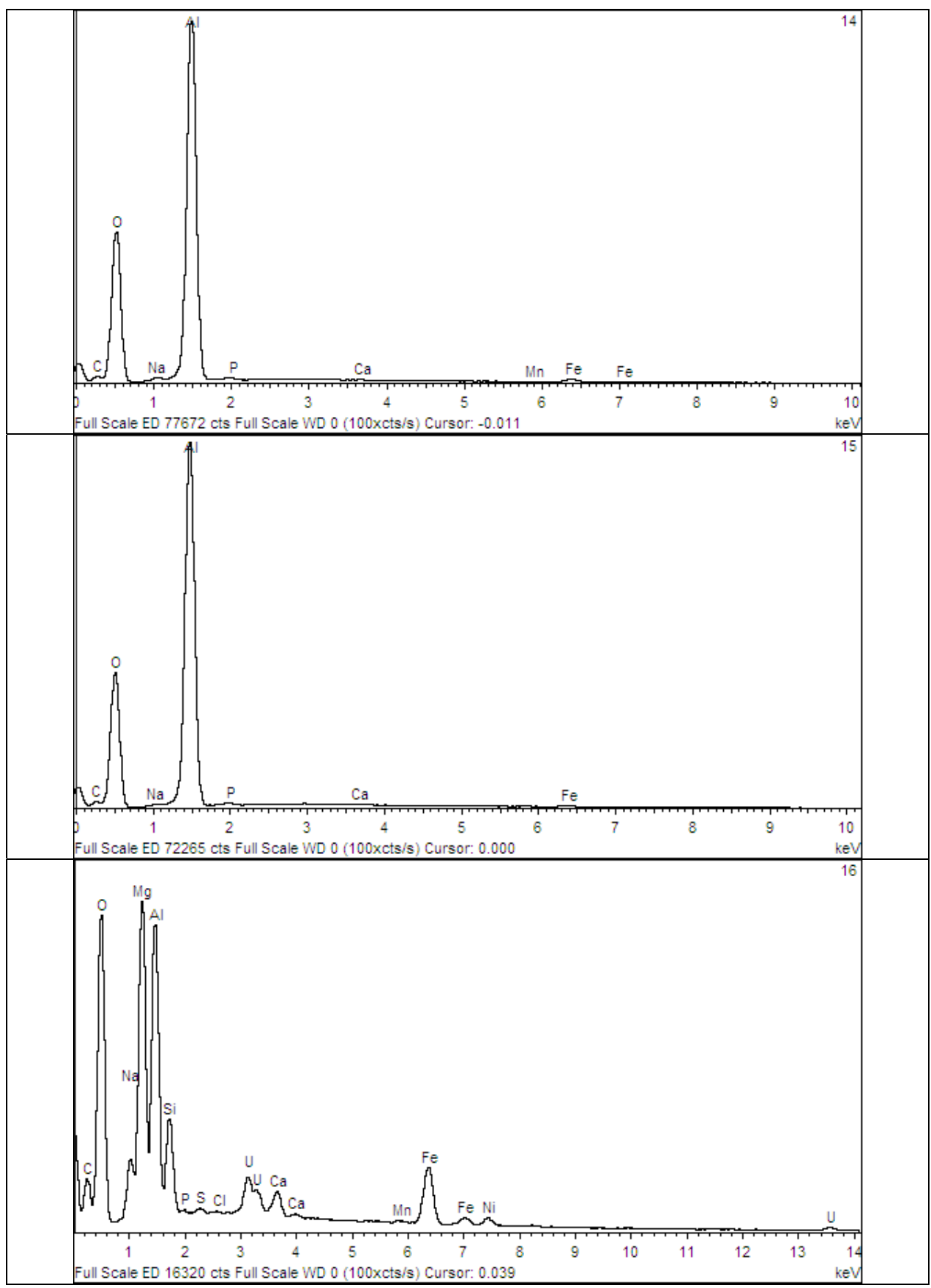

Figure A-12 EDS Grid Analysis of Spots on Particles in Sample FTF-18-4 (continued) 
SRNL-STI-2012-00123

Revision 0

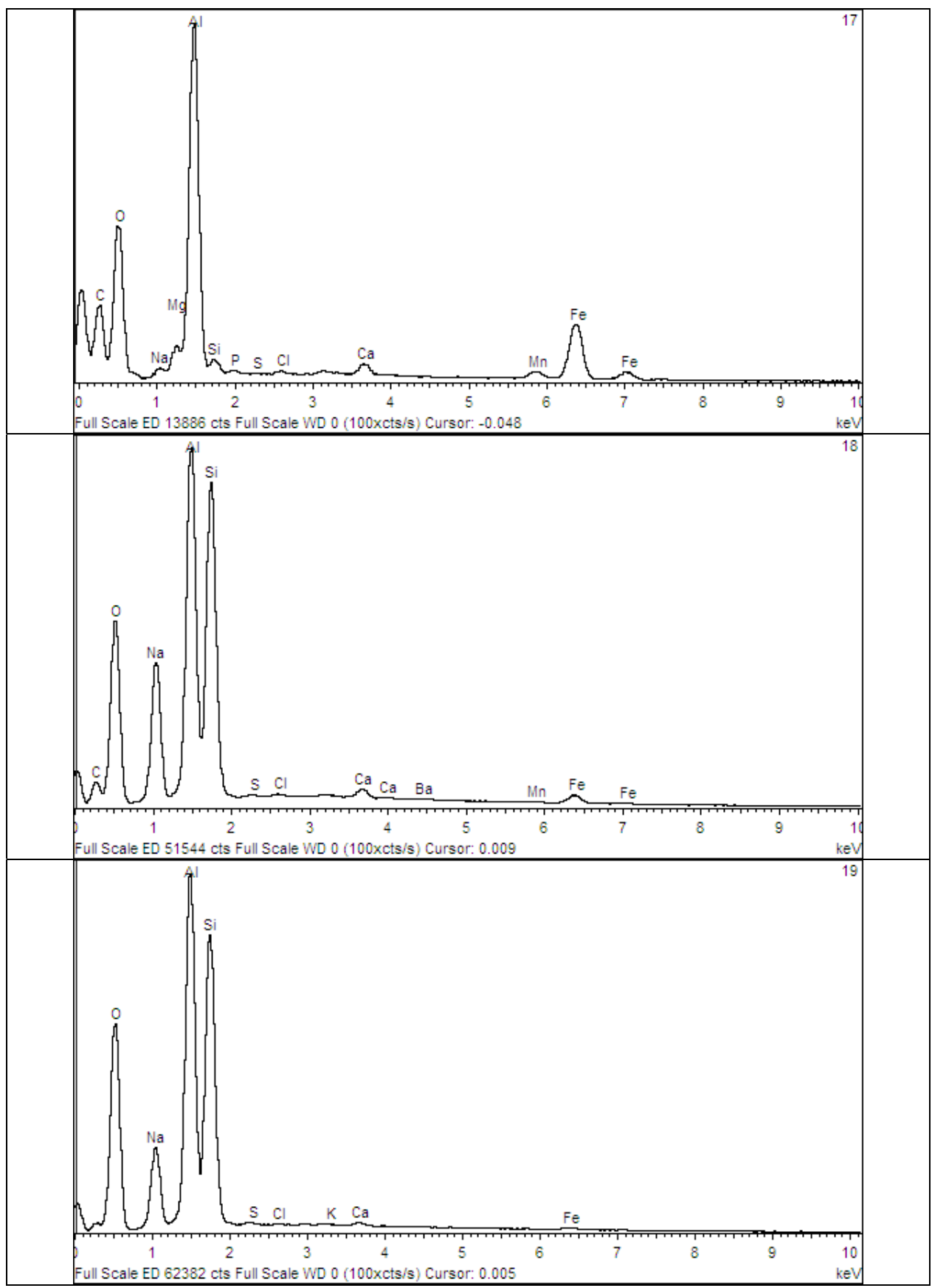

Figure A-12 EDS Grid Analysis of Spots on Particles in Sample FTF-18-4 (continued) 
SRNL-STI-2012-00123

Revision 0

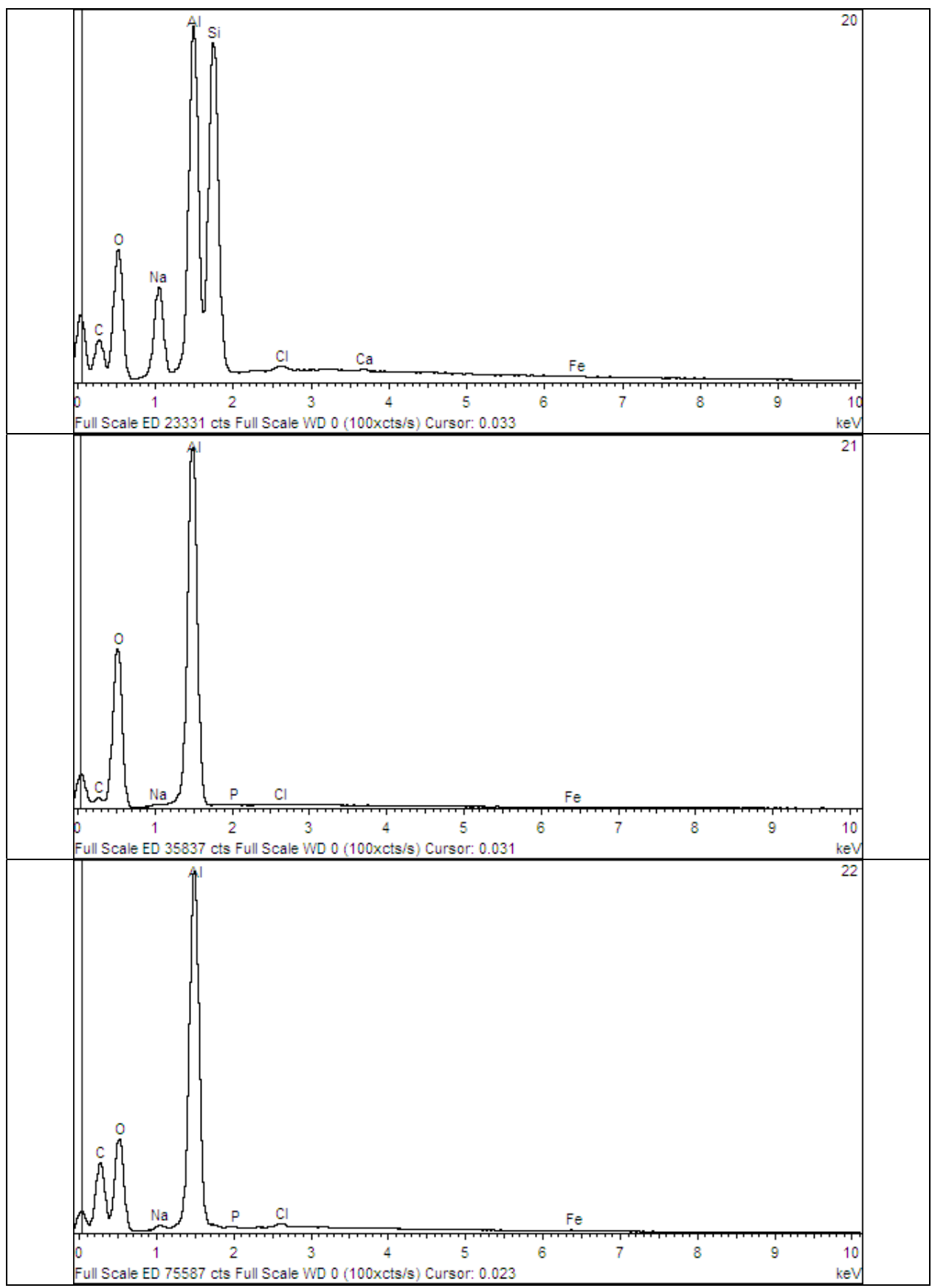

Figure A-12 EDS Grid Analysis of Spots on Particles in Sample FTF-18-4 (continued) 
SRNL-STI-2012-00123

Revision 0

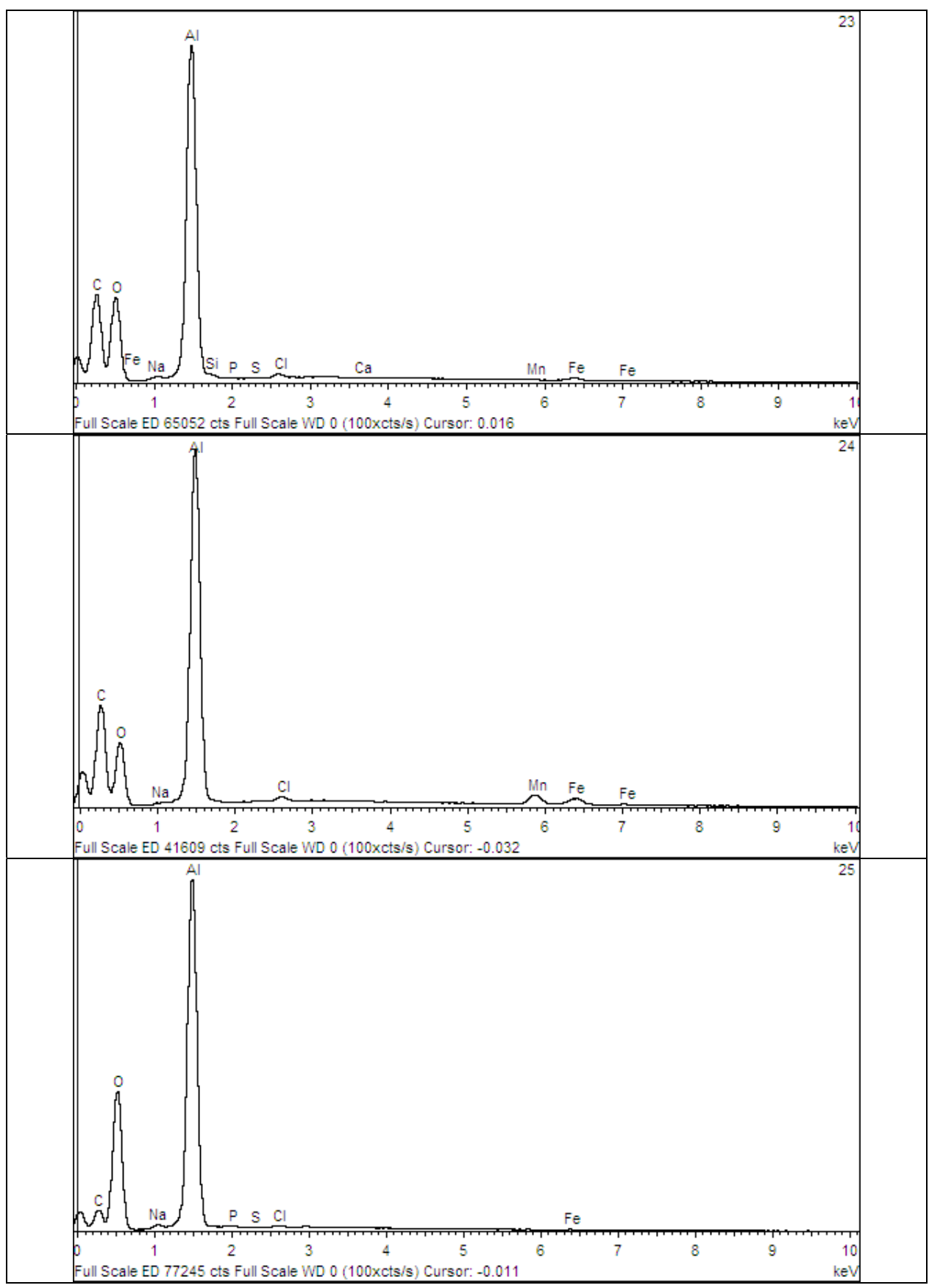

Figure A-12 EDS Grid Analysis of Spots on Particles in Sample FTF-18-4 (continued) 
SRNL-STI-2012-00123

Revision 0

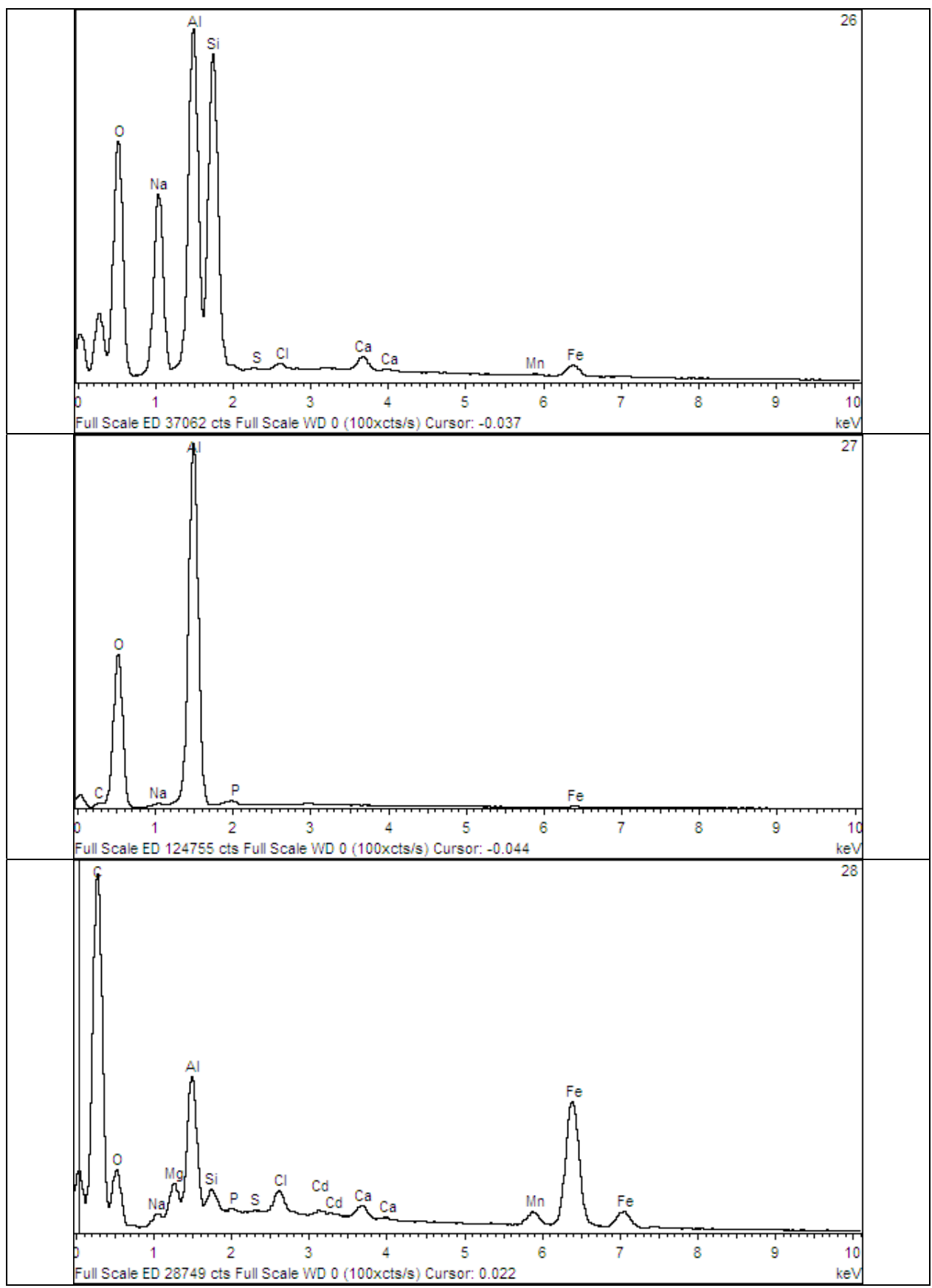

Figure A-12 EDS Grid Analysis of Spots on Particles in Sample FTF-18-4 (continued) 
SRNL-STI-2012-00123

Revision 0

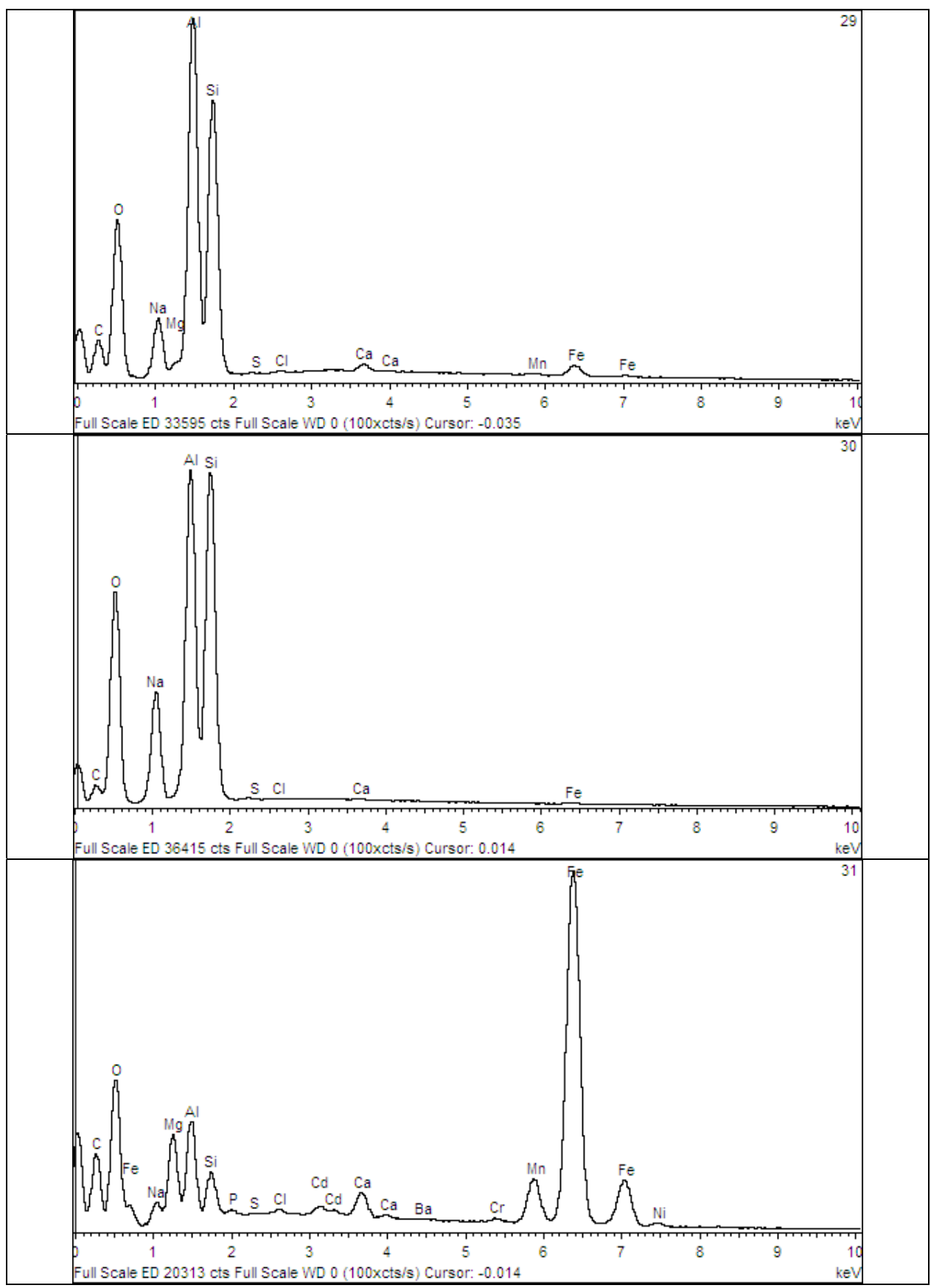

Figure A-12 EDS Grid Analysis of Spots on Particles in Sample FTF-18-4 (continued) 